RODRIGO UBUKATA

Avaliação do estado oxidante I antioxidante sistêmico e das defesas antioxidantes eritrocitárias em cães com linfoma multicêntrico com e sem anemia

São Paulo 2010 


\section{Avaliação do estado oxidante / antioxidante sistêmico e das defesas antioxidantes eritrocitárias em cães com linfoma multicêntrico com e sem anemia}

Dissertação apresentada ao Programa de PósGraduação em Clínica Veterinária da Faculdade de Medicina Veterinária e Zootecnia da Universidade de São Paulo para a obtenção do título de Mestre em Ciências

\section{Departamento:}

Clínica Médica

Área de Concentração:

Clínica Veterinária

Orientador:

Profa. Dra. Sílvia Regina Ricci Lucas

São Paulo 
Autorizo a reprodução parcial ou total desta obra, para fins acadêmicos, desde que citada a fonte.

\section{DADOS INTERNACIONAIS DE CATALOGAÇÃO-NA-PUBLICAÇÃO}

(Biblioteca Virginie Buff D’Ápice da Faculdade de Medicina Veterinária e Zootecnia da Universidade de São Paulo)

Ubukata, Rodrigo

Avaliação do estado oxidante / antioxidante sistêmico e das defesas antioxidantes eritrocitárias em cães com linfoma multicêntrico com e sem anemia / Rodrigo Ubukata. -- 2010.

$89 \mathrm{f}$. : il.

Dissertação (mestrado) - Universidade de São Paulo. Faculdade de Medicina Veterinária e Zootecnia. Departamento de Clínica Médica, São Paulo, 2010.

Programa de Pós-Graduação: Clínica Veterinária.

Área de concentração: Clínica Veterinária.

Orientador: Profa. Dra. Sílvia Regina Ricci Lucas.

1. Cães. 2. Linfoma multicêntrico. 3. Glutationa reduzida. 4. Estresse oxidativo. 5. Anemia. I. Título. 


\begin{tabular}{cccc}
\hline & \multicolumn{2}{c}{ ERRATA } \\
Folha & Linha & Onde se lê & Leia-se \\
Ficha catalográfica & 5 & $89 \mathrm{f}$. & $90 \mathrm{f}$. \\
Resumo & 4 & $89 \mathrm{f}$. & $90 \mathrm{f}$. \\
Abstract & 4 & $89 \mathrm{f}$. & $90 \mathrm{f}$. \\
\hline
\end{tabular}




\section{UNIVERSIDADE DE SÃO PAULO \\ Faculdade de Medicina Veterinária e Zootecnia \\ Comissño Bioética}

CERTIFICADO

Certificamos que o Projeto intitulado "Avaliação do estresse oxidativo eritrocitário em căes com linfoma multicêntrico", protocolado sob o n'1122/2007, utilizando 40 (quarenta) càes, sob a responsabilidade da Profa. Dra. Silvia Regina Ricci Lucas, está de acordo com os princípios éticos de experimentação animal da Comissão de Bioética da Faculdade de Medicina Veterinária e Zootecnia da Universidade de São Paulo e foi aprovado em reunião de 22/08/07.

We certify that the Research "Erythrocyte oxidative stress evaluation in dogs with multicentric lymphoma", protocol number $1122 / 2007$, utilizing 40 (forty) dogs, under the responsibility Profa. Dra. Silvia Regina Ricci Lucas, agree with Ethical Principles in Animal Research adopted by Bioethic Commission of the School of Veterinary Medicine and Animal Science of University of Säo Paulo and was approved in the meeting of day 08/22/07.

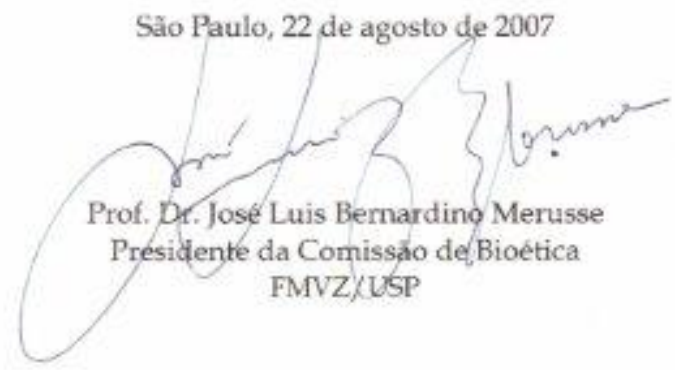

Av. Prof. Dr. Orlando Marques de Paiva, $\pi^{\circ} 87$ - 05508-270 - Cidade Universitária "Armando de Salles Oliveira". Fax: (11) 3032-2224 - fones: (11) 309107676/7671 - e-mail: fmvzidedu usp.br 


\section{FOLHA DE AVALIAÇÃO}

Nome: UBUKATA, Rodrigo

Título: Avaliação do estado oxidante / antioxidante sistêmico e das defesas antioxidantes eritrocitárias em cães com linfoma multicêntrico com e sem anemia

Dissertação apresentada ao Programa de PósGraduação em Clínica Veterinária da Faculdade de Medicina Veterinária e Zootecnia da Universidade de São Paulo para a obtenção do título de Mestre em Ciências

Data: $/ 2010$

\section{Banca Examinadora}

Prof. Dr. Instituição:

Assinatura: Julgamento:

Prof. Dr. Instituição:

Assinatura: Julgamento:

Prof. Dr. Instituição:

Assinatura: Julgamento: 
Aos meus avós,

\section{Mitsuo e Fuku Ubukata}

Sadao (in memoriam) e Yoshiko Nakashima imigrantes japoneses que ao chegarem neste país, sonharam melhores condições de vida e hoje, colhem através de seus netos a realização pela valorização aos estudos que sempre incentivaram.

Aos meus pais, Mário e Helena

por sempre estarem ao meu lado,

apoiando-me e incentivando-me em todos os momentos.

À minha irmã, Sandra

pela ajuda essencial para que

eu aqui chegasse. 
À minha orientadora

Profa. Dra. Sílvia Regina Ricci Lucas

Pela confiança, orientação e ensinamentos

Pela amizade e compreensão

A Oncologia Veterinária avança com suas contribuições 


\section{AGRADECIMENTOS}

À Fundação de Amparo à Pesquisa do Estado de São Paulo (FAPESP), pela concessão do Auxílio à Pesquisa (Processo n. ${ }^{\circ}$ 06/61161-8) que viabilizou a realização deste estudo.

À Faculdade de Medicina Veterinária e Zootecnia da Universidade de São Paulo pela acolhida.

À Profa. Dra. Renata Afonso Sobral, minha primeira orientadora na Oncologia, amiga e sócia pelo incentivo e apoio desde o início da minha vida profissional.

À Clara Satsuki Mori, por sua paciência e ensinamentos durante a execução dos experimentos.

À médica veterinária e mestre, Samantha Ive Miyashiro, pela leitura de todos os mielogramas, ensinamentos e apoio durante todo o período da pós-graduação.

À pós-graduanda e amiga Thaís Rodrigues Macedo, pelo companheirismo e ajuda durante todas as etapas do experimento. Sem sua ajuda não teria conseguido.

Aos pós-graduandos e amigos Camila Ferreiro Pinto e Lucas Campos de Sá Rodrigues, pela inestimável colaboração. 
A todos os colegas do Programa de Pós-Graduação em Clínica Veterinária pelo convívio e aprendizado.

À Profa. Dra. Mitika Kuribayashi Hagiwara pelos ensinamentos durante a disciplina de Hematologia que foram fundamentais para a execução desta pesquisa.

À Profa. Dra. Márcia Mery Kogika, pelos socorros de última hora.

Ao Prof. Dr. Cássio Xavier de Mendonça Júnior pela inestimável ajuda com as análises estatísticas.

Às Professoras Doutoras Alice Maria Melville Paiva Della Libera e Carmen Helena de Carvalho Vasconcellos pela ajuda ao ingresso na pós-graduação.

Aos médicos veterinários do Serviço de Clínica Médica de Pequenos Animais do Hospital Veterinário da FMVZ-USP, Vera A. B. Fortunato Wirthl, Denise Maria Nunes Simões, Bruna Maria Pereira Coelho, Paula Rumy Gonçalves Monteiro e Khadine Kanayama pela inestimável ajuda na seleção dos animais com linfoma multicêntrico.

Aos funcionários do Serviço de Clínica Médica de Pequenos Animais do Hospital Veterinário da FMVZ-USP, Toninho, Carlito, Geraldo, Milton e Gilberto, sempre prontos a colaborar.

Ao médico veterinário do Serviço de Anestesia do Hospital Veterinário da FMVZ-USP, João Luiz Krumenerl Júnior por anestesiar os pacientes para colheita dos mielogramas. 
À médica veterinária do Serviço de Laboratório Clínico do Hospital Veterinário da FMVZUSP, Maria Luísa Franchini e técnicas Claúdia, Marli, Maria Helena, Creide, Dinha e Carmem pela colaboração na realização dos exames laboratoriais.

Às médicas veterinárias do Serviço de Diagnóstico por Imagem do Hospital Veterinário da FMVZ-USP, Luciane Kanayama e Silvana Unruh por sempre encaixarem os pacientes para realização dos exames de ultra-som e raio-X, fundamentais para o estadiamento dos pacientes.

À médica veterinária do Serviço de Patologia Animal do Hospital Veterinário da FMVZ-USP, Luciana Neves Torres pela realização dos exames histopatológicos e citológicos quando necessários.

Às médicas veterinárias e amigas Adriana Lima Teixeira, Ana Luiza Chierichetti e Cláudia Souza Kronfly sempre presentes em minha vida, nunca deixando desanimar, apoiando-me e incentivando-me. Não tenho palavras para expressar meus sentimentos por vocês.

Às médicas veterinárias do Setor de Oncologia Veterinária do PROVET - Unidade Divino Salvador: Suzana Terumi Honda, Roberta Fernandes Portela, Juliana Vieira Cirillo, Adriana Tomoko Nishiya e Fernanda Duarte dos Santos Malatesta pelo apoio e socorro nos momentos em que precisei me ausentar da rotina do Serviço para conclusão do experimento.

Aos funcionários do PROVET - Unidade Divino Salvador: Sandra, Jean, Adlane e Cléia que sempre me ajudaram aliviando-me de problemas durante todo o período da pós-graduação.

Aos médicos veterinários e amigos do PROVET - Unidade Divino Salvador: Márcia Kahvegian, André Leguthe, Edilberto de Oliveira Rodrigues, Fernando Barros de Nóbrega Maia, Elaine Souza Melo, Herbert Corrêa, Michèle Venturini, Paulo Moya, Celina Okamoto, Karina Yazbek, Franz Naoki Yoshitoshi e Fernanda Auler. 
Aos amigos do SCAN - Saúde e Ciência Animal (Campinas): José Casuiochi Murashima Júnior, Eduardo Sotelo Salcedo, Daniela Chiquetto, Danielle Graziani Prada, Nádia de Oliveira Ferraz, Silvana Massuqueto e Daniela de Godoy.

Aos médicos veterinários e amigos Mônica Leão Veras e José Roberto da Clínica Veterinária Pet Plus, todos os alunos e residentes da FMVZ-USP entre os anos de 2008 e 2010 por autorizarem a colheita de sangue de seus cães para compor o grupo controle.

Aos membros da Diretoria e Conselho Consultivo da Associação Brasileira de Oncologia Veterinária triênio 2007-2010 pela convivência. O VI ONCOVET foi um sucesso.

À secretária de pós-graduação do Departamento de Clínica Médica da FMVZ-USP, Adelaide Fátima de Jesus Borges pela ajuda durante o curso.

Ao Serviço de Biblioteca e Documentação da Faculdade de Medicina Veterinária e Zootecnia da Universidade de São Paulo, Elza Maria R. B. Faquim, pela ajuda na conclusão desta obra.

A todos os pacientes e seus proprietários que contribuíram para esta pesquisa aceitando a participar dela e assim, desenvolver a Oncologia Veterinária. 


\section{RESUMO}

UBUKATA, R. Avaliação do estado oxidante / antioxidante sistêmico e das defesas antioxidantes eritrocitárias em cães com linfoma multicêntrico com e sem anemia. [Evaluation of the systemic oxidant / antioxidant status and erythrocyte antioxidant defenses in dogs with multicentric lymphoma with and without anemia]. 2010. 89 f. Dissertação (Mestrado em Ciências) - Faculdade de Medicina Veterinária e Zootecnia, Universidade de São Paulo, São Paulo - 2010.

Anemia é a anormalidade hematológica mais comum em pacientes com câncer. Aproximadamente $30 \%$ dos cães com linfoma são anêmicos. A anemia pode ocorrer devido substituição da medula óssea por células tumorais, sangramentos ou hemólise, porém mais frequentemente é associada à doença crônica. Estudos realizados em seres humanos com neoplasias hematopoiéticas demonstraram que a diminuição das defesas antioxidantes eritrocitárias e aumento na concentração de marcadores de peroxidação lipídica no plasma são responsáveis pelo estresse oxidativo e ocorrência da anemia. Foram objetivos deste estudo determinar as concentrações eritrocitárias de glutationa reduzida e as atividades das enzimas antioxidantes eritrocitárias glutationa redutase, glutationa peroxidase, além de substâncias reativas ao ácido tiobarbitúrico e o estado antioxidante total em cães hígidos e com linfoma multicêntrico com e sem anemia, para avaliar a influência dos mecanismos oxidativos no desenvolvimento das anemias associadas a essa neoplasia. Foram observadas reduções significativas nas concentrações eritrocitárias de glutationa reduzida e glutationa peroxidase nos cães com linfoma multicêntrico e com anemia ( $p<0,001$ e $p<0,01$, respectivamente). Não houve diferença significativa na avaliação das concentrações eritrocitárias de glutationa redutase e substâncias reativas ao ácido tiobarbitúrico, entretanto as concentrações plasmáticas de substâncias reativas ao ácido tiobarbitúrico eram maiores no grupo de cães com linfoma multicêntrico e com anemia $(0,94 \mu \mathrm{mol} / \mathrm{L} \pm 0,72$; média \pm desvio padrão). Os valores do estado antioxidante total foram significativamente menores $(p<0,001)$ nos cães com linfoma multicêntrico e com anemia $(0,60 \mu \mathrm{mol} / \mathrm{L} \pm 0,12)$ do que nos animais hígidos $(0,87 \mu \mathrm{mol} / \mathrm{L} \pm 0,11)$. Os resultados obtidos indicam um aumento do estresse oxidativo principalmente nos cães com linfoma multicêntrico e com anemia pela diminuição das defesas antioxidantes, representadas pelo estado antioxidante total e glutationa reduzida intraeritrocitária e pela tendência a maior aumento das concentrações plasmáticas de 
substâncias reativas ao ácido tiobarbitúrico, podendo estas alterações contribuir para a ocorrência de anemia em cães com linfoma multicêntrico.

Palavras-chave: Cães. Linfoma multicêntrico. Glutationa reduzida. Estresse oxidativo. Anemia. 


\begin{abstract}
UBUKATA, R. Evaluation of the systemic oxidant / antioxidant status and erythrocyte antioxidant defenses in dogs with multicentric lymphoma with and without anemia. [Avaliação do estado oxidante / antioxidante sistêmico e das defesas antioxidantes eritrocitárias em cães com linfoma multicêntrico com e sem anemia]. 2010. 89 f. Dissertação (Mestrado em Ciências) - Faculdade de Medicina Veterinária e Zootecnia, Universidade de São Paulo, São Paulo - 2010.
\end{abstract}

Anemia is the most common hematological abnormality in cancer patients. Approximately $30 \%$ of dogs with lymphoma are anemic. Anemia can occur due to bone marrow replacement by tumor cells, bleeding or hemolysis, but more often is associated with chronic disease. Researches in human hematopoietic malignancies demonstrated that reduction of erythrocyte antioxidant defenses and increased concentrations of markers of lipid peroxidation in the plasma are responsible for the occurrence of oxidative stress and anemia. This study was designed to measure the concentration of erythrocyte reduced glutathione and antioxidant enzyme activities of erythrocyte glutathione reductase, glutathione peroxidase, and thiobarbituric acid reactive substances and total antioxidant status in healthy dogs and with multicentric lymphoma with or without anemia, to evaluate the influence of oxidative mechanisms in the development of anemia associated with this neoplasia. Significant reductions were observed in erythrocyte concentrations of reduced glutathione and glutathione peroxidase in dogs with multicentric lymphoma and anemia $(\mathrm{p}<0.001$ and $\mathrm{p}<$ 0.01 , respectively). There was no significant difference in the assessment of concentrations of erythrocyte glutathione reductase and thiobarbituric acid reactive substances, although concentrations of plasma thiobarbituric acid reactive substances were higher in dogs with multicentric lymphoma and anemia $(0.94 \mu \mathrm{mol} / \mathrm{L} \pm 0.72$, mean \pm standard deviation $)$. The values of total antioxidant status were significantly lower $(\mathrm{p}<0.001)$ in dogs with multicentric lymphoma and anemia $(0.60 \mu \mathrm{mol} / \mathrm{L} \pm 0.12)$ than in healthy animals $(0.87$ $\mathrm{mmol} / \mathrm{L} \pm 0.11)$. The results indicate an increased oxidative stress, especially in dogs with multicentric lymphoma with anemia and the decrease of antioxidant defenses, represented by the total antioxidant status and intraerythrocytic reduced glutathione and the trend to greater increase in plasma thiobarbituric acid reactive substances and may these changes contribute to the occurrence of anemia in dogs with multicentric lymphoma. 
Keywords: Dogs. Multicentric lymphoma. Reduced glutathione. Oxidative stress. Anemia. 


\section{LISTA DE APÊNDICES}

APÊNDICE A - Valores relativos aos hemogramas dos animais do grupo controle. São Paulo, 2010

APÊNDICE B - Valores relativos aos exames bioquímicos séricos dos animais do grupo controle. São Paulo, 2010

APÊNDICE C - Valores relativos aos hemogramas dos animais com linfoma multicêntrico do grupo experimental sem anemia. São Paulo, 2010 ...

APÊNDICE D - Valores relativos aos exames bioquímicos séricos dos animais com linfoma multicêntrico do grupo experimental sem anemia. São Paulo, 2010

APÊNDICE E - Valores relativos aos hemogramas dos animais com linfoma multicêntrico do grupo experimental com anemia. São Paulo, 2010 ...

APÊNDICE F - Valores relativos aos exames bioquímicos séricos dos animais com linfoma multicêntrico do grupo experimental com anemia. São Paulo, 2010

APÊNDICE G - Avaliação dos mielogramas relativos aos animais com linfoma multicêntrico do grupo experimental sem anemia. São Paulo, 2010 ....

APÊNDICE H - Avaliação dos mielogramas relativos aos animais com linfoma multicêntrico do grupo experimental com anemia. São Paulo, 2010 .... 


\section{LISTA DE QUADROS}

Quadro 1 - Caracterização dos cães hígidos que compuseram o grupo controle. São Paulo, 2010

Quadro 2 - Caracterização dos cães com linfoma multicêntrico que compuseram o grupo experimental sem anemia. São Paulo, 2010

Quadro 3 - Caracterização dos cães com linfoma multicêntrico que compuseram o grupo experimental com anemia. São Paulo, 2010 


\section{LISTA DE TABELAS}

Tabela 1 - Hematócrito (Ht), valores individuais, mínimo e máximo (Mín-Máx), médias, medianas e desvios padrão da média (DP) da glutationa reduzida (GSH), glutationa peroxidase (GPX), glutationa redutase (GR), substâncias reativas ao ácido tiobarbitúrico (TBARS) e estado antioxidante total (TAS) de cães do grupo controle (sadios). São Paulo, 2010

Tabela 2 - Hematócrito (Ht), valores individuais, mínimo e máximo (Mín-Máx), médias, mediana e desvios padrão da média (DP) da glutationa reduzida (GSH), glutationa peroxidase (GPX), glutationa redutase (GR), substâncias reativas ao ácido tiobarbitúrico (TBARS) e estado antioxidante total (TAS) de cães do grupo experimental com linfoma multicêntrico e sem anemia. São Paulo, 2010

Tabela 3 - Hematócrito $(\mathrm{Ht})$, valores individuais, mínimo e máximo (Mín-Máx), médias, mediana e desvios padrão da média (DP) da glutationa reduzida (GSH), glutationa peroxidase (GPX), glutationa redutase (GR), substâncias reativas ao ácido tiobarbitúrico (TBARS) e estado antioxidante total (TAS) de cães do grupo experimental com linfoma multicêntrico e anemia. São Paulo, 2010

Tabela 4 - Valores de significância das concentrações eritrocitárias de glutationa reduzida (GSH), glutationa peroxidase (GPX), glutationa redutase (GR), substâncias reativas ao ácido tiobarbitúrico (TBARS) e estado antioxidante total (TAS) entre os grupos controle (sadios), grupo experimental com linfoma multicêntrico e sem anemia, grupo experimental com linfoma multicêntrico e com anemia e grupo experimental doente (com linfoma multicêntrico com e sem anemia). São Paulo, 2010 


\section{LISTA DE GRÁFICOS}

Gráfico 1 - Representação dos valores de mediana (linha central) e mínimo e máximo (delimitação do quadrilátero) do hematócrito (\%) dos cães do grupo controle, cães com linfoma multicêntrico e sem anemia e cães com linfoma multicêntrico e com anemia. São Paulo, 2010

Gráfico 2 - Representação dos valores de mediana (linha central) e mínimo e máximo (delimitação do quadrilátero) da glutationa reduzida eritrocitária $(\mathrm{mg} / \mathrm{dL})$ dos cães do grupo controle, cães com linfoma multicêntrico e sem anemia e cães com linfoma multicêntrico e com anemia. São Paulo, 2010

Gráfico 3 - Representação dos valores de mediana (linha central) e mínimo e máximo (delimitação do quadrilátero) da glutationa peroxidase eritrocitária $(\mathrm{U} / \mathrm{g} \mathrm{Hb})$ dos cães do grupo controle, cães com linfoma multicêntrico e sem anemia e cães com linfoma multicêntrico e com anemia. São Paulo, 2010

Gráfico 4 - Representação dos valores de mediana (linha central) e mínimo e máximo (delimitação do quadrilátero) da glutationa redutase eritrocitária $(\mathrm{U} / \mathrm{g} \mathrm{Hb})$ dos cães do grupo controle, cães com linfoma multicêntrico e sem anemia e cães com linfoma multicêntrico e com anemia. São Paulo, 2010

Gráfico 5 - Representação dos valores de mediana (linha central) e mínimo e máximo (delimitação do quadrilátero) das concentrações plasmáticas das substâncias reativas ao ácido tiobarbitúrico (TBARS) ( $\mu \mathrm{mol} / \mathrm{L})$ dos cães do grupo controle, cães com linfoma multicêntrico e sem anemia e cães com linfoma multicêntrico e com anemia. São Paulo, 2010

Gráfico 6 - Representação dos valores de mediana (linha central) e mínimo e máximo (delimitação do quadrilátero) do estado antioxidante total (TAS) $(\mu \mathrm{mol} / \mathrm{L})$ dos cães do grupo controle, cães com linfoma multicêntrico e sem anemia e cães com linfoma multicêntrico e com anemia. São Paulo, 2010 
Gráfico 7 - Curva de regressão entre os valores de hematócrito e os valores intraeritrocitários de glutationa reduzida (GSH) dos cães sadios e com linfoma multicêntrico com e sem anemia. São Paulo, 2010

Gráfico 8- Curva de regressão entre os valores de hematócrito e os valores intraeritrocitários de glutationa peroxidase (GPX) dos cães sadios e com linfoma multicêntrico com e sem anemia. São Paulo, 2010

Gráfico 9 - Curva de regressão entre os valores de hematócrito e os valores do estado antioxidante total (TAS) dos cães sadios e com linfoma multicêntrico com e sem anemia. São Paulo, 2010

Gráfico 10 - Curva de regressão entre os valores de hematócrito e os valores intraeritrocitários de glutationa redutase (GR) dos cães sadios e com linfoma multicêntrico com e sem anemia. São Paulo, 2010

Gráfico 11 - Curva de regressão entre os valores de hematócrito e os valores da concentração plasmática das substâncias reativas ao ácido tiobarbitúrico (TBARS) dos cães sadios e com linfoma multicêntrico com e sem anemia. São Paulo, 2010

Gráfico 12 - Curva de regressão entre os valores intraeritrocitários de glutationa reduzida (GSH) e valores intraeritrocitários de glutationa redutase (GR) dos cães sadios e com linfoma multicêntrico com e sem anemia. São Paulo, 2010

Gráfico 13 - Curva de regressão entre os valores intraeritrocitários de glutationa reduzida (GSH) e valores do estado antioxidante total (TAS) dos cães sadios e com linfoma multicêntrico com e sem anemia. São Paulo, 2010.

Gráfico 14 - Curva de regressão entre os valores intraeritrocitários de glutationa reduzida (GSH) e valores da concentração plasmática das substâncias reativas ao ácido tiobarbitúrico (TBARS) dos cães sadios e com linfoma multicêntrico com e sem anemia. São Paulo, 2010 


\section{SUMÁRIO}

INTRODUÇÃO

MATERIAL E MÉTODO …................................................. 32

Determinação intraeritrocitária de glutationa reduzida (GSH) .

Determinação intraeritrocitária de glutationa peroxidase (GPX)

Determinação da concentração plasmática das substâncias reativas ao ácido tiobarbitúrico (TBARS)

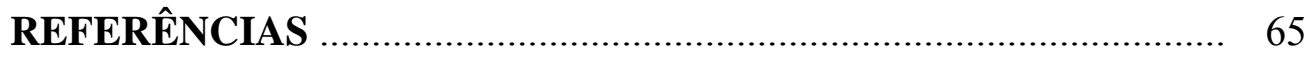

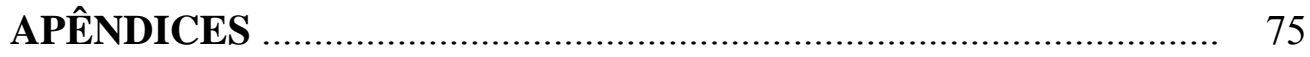




\section{INTRODUÇÃO}

Linfomas são neoplasias malignas de elevada complexidade biológica caracterizadas pela proliferação e transformação de células linfóides e que acometem seres humanos e várias espécies animais (JAIN, 1993). Originam-se em linfonodos ou órgãos viscerais sólidos como baço e fígado (VAIL; THAMM, 2005).

São as neoplasias hematopoiéticas mais relatadas em cães. A doença pode ocorrer em qualquer idade, entretanto, cães de meia idade e idosos representam $80 \%$ dos casos (MOULTON; HARVEY, 1990).

O linfoma canino é classificado segundo sua localização anatômica, estágio clínico (Organização Mundial de Saúde - OMS), critérios cito-histológicos e imunofenotípicos (OWEN, 1980; VAIL; THAMM, 2005). Quanto à localização anatômica, os linfomas classificam-se, segundo Moulton e Harvey (1990), em multicêntrico, mediastínico, alimentar e misto.

A forma mediastínica envolve o timo (forma tímica) e/ou os linfonodos mediastinais craniais e caudais, caracterizando-se pelo aparecimento agudo de distrição respiratória, taquipnéia, tosse, regurgitação, anorexia, caquexia e letargia (VAIL; YOUNG, 2007).

O linfoma alimentar caracteriza-se pela presença da neoplasia no trato gastrintestinal e/ou linfonodos mesentéricos (WELLMAN, 1996). Os sintomas podem estar associados com obstrução intestinal ou diarréias, que são observadas em $80 \%$ dos cães acometidos sendo que, alguns, apresentam sangue nas fezes (MOULTON; HARVEY, 1990).

O linfoma misto corresponde à neoplasia extranodal que pode afetar qualquer tecido corpóreo, com várias manifestações clínicas (COUTO, 1992). Por exemplo, quando acomete os olhos causa uveíte, glaucoma e hifema, já quando ocorre no cérebro leva a convulsões (WHITFORD, 1965; SLATTER, 1992). Na pele, o linfoma pode ser classificado como epiteliotrópico e não-epiteliotrópico, na dependência das camadas da pele infiltradas pelos linfócitos (WILKINSON; HARVEY, 1996). 
O linfoma multicêntrico acomete os linfonodos superficiais e profundos, baço, fígado, tonsilas e medula óssea, caracterizando-se por linfonodomegalia, principalmente de poplíteos, mandibulares, cervicais superficiais e axilares (GREENE, 1996; HARVEY, 1996). Nessa forma, podem ocorrer hepatomegalia e esplenomegalia, em consequência da infiltração neoplásica (MOULTON; HARVEY, 1990). Oitenta a 85\% dos casos de linfomas em cães manifestam-se dessa forma (VAIL; THAMM, 2005).

Os estágios clínicos são classificados de $\mathrm{I}$ a $\mathrm{V}$ e subclassificados em assintomáticos (letra "a" após o algarismo romano que representa o estágio) e sintomáticos (letra "b"). O estágio I é aquele em que ocorre envolvimento de um linfonodo ou tecido linfóide de único órgão, excluindo a medula óssea. Estágio II é o envolvimento de vários linfonodos em uma mesma região anatômica. Quando a linfonodomegalia é generalizada, classifica-se como estágio III. Envolvimento de baço e/ou fígado com ou sem doença em estágio III é classificado como estágio IV. O estágio V é a manifestação no sangue e envolvimento da medula óssea acompanhada ou não dos estágios I a IV (VAIL; YOUNG, 2007).

Weiss (2006) em seu estudo para classificar as afecções da medula óssea em cães, observou que a condição neoplásica mais comumentemente diagnosticada nas amostras foi o linfoma. A porcentagem de células malignas na medula óssea variou entre 6 e $68 \%$.

O linfoma, assim como outros tipos de cânceres, promove nos pacientes, além dos efeitos relacionados diretamente ao tumor, outras alterações indiretas. Esse grupo de alterações recebe a denominação de síndromes paraneoplásicas e representa um conjunto de manifestações que ocorrem no organismo em locais distantes do tumor primário ou de suas metástases. As síndromes paraneoplásicas podem afetar diferentes sistemas orgânicos. Os efeitos remotos da doença têm como resultado sintomas que necessitam ser reconhecidos e tratados, já que muitas vezes são os primeiros sinais de uma neoplasia ainda não diagnosticada (OGILVIE, 2000; FINORA, 2003).

As síndromes paraneoplásicas mais comumentemente relacionadas com tumores hematopoiéticos são: anemia, eritrocitose, leucocitose, alterações da coagulação, gamopatias, anorexia/caquexia, febre de origem desconhecida, hipercalcemia, hipoglicemia e miastenia gravis (WELLER, 1985).

Alterações eritrocitárias são as anormalidades hematológicas mais frequentemente observadas em animais com câncer. Acredita-se que aproximadamente $30 \%$ dos cães com 
linfoma sejam anêmicos (WELLER, 1985). O tipo de anemia observada geralmente é normocítica, normocrômica e arregenerativa (WELLER, 1985; MACCIÒ et al., 2005; VAIL; THAMM, 2005), conhecida como anemia de doença crônica (WELLER, 1985; VAIL; THAMM, 2005). Em humanos, associa-se também a anemia hemolítica imunemediada como uma complicação hematológica no linfoma (BEWICK; COUTIE; TUDHOPE, 1987).

A incidência e gravidade da anemia dependem do tipo e extensão da neoplasia. Pode ocorrer como resultado do tumor (comprometimento da medula óssea por infiltração das células neoplásicas), tratamento do câncer, perda sanguínea, hemólise (devido mecanismos imunemediados) ou citocinas inflamatórias associadas com doença crônica (MADEWELL; FELDMAN, 1980; KOBUNE; KATO; NIITSU, 2008).

A anemia de doença crônica é definida como aquela que ocorre em infecções crônicas, alterações inflamatórias ou neoplásicas e que não tem relação com a infiltração da medula pelo tumor, sangramento ou hemólise e que é caracterizada pela hipoferremia, na presença de estoques adequados de ferro (MEANS; KRANTZ, 1992).

Segundo Cartwright ${ }^{1}$ (1966 apud MEANS; KRATZ, 1992, p. 1639) pelo menos três processos patológicos estão envolvidos na anemia de doença crônica: menor tempo de vida do eritrócito, falha da medula óssea em aumentar a produção de células vermelhas para compensar o aumento da demanda e menor liberação de ferro para o sistema reticuloendotelial (pelo sequestro do ferro pelo sistema mononuclear fagocitário [FELDMAN, 2005]). Esse tipo de anemia é também conhecida como anemia da doença inflamatória (FELDMAN, 2005; WEISS, 2009) já que é induzida por citocinas produzidas durante a inflamação que acompanha o desenvolvimento de neoplasias, entre elas o linfoma no cão (FELDMAN, 2005). Em humanos, pacientes com neoplasias hematológicas apresentam alta incidência de anemia (BISHOP; FAITHFULL; ALLAN, 2010).

A anemia é reconhecida como um fator preditivo independente para um mau prognóstico em pacientes com câncer (CARO et al., 2001; HARPER; LITTLEWOOD, 2005; BIRGEGARD; GASCÓN; LUDWIG, 2006). Abbo e Lucroy (2007), concluíram em seu estudo retrospectivo com 96 cães com linfoma, que a anemia é um fator de risco para baixa resposta ao tratamento quimioterápico e menor tempo de sobrevida. Miller et

\footnotetext{
${ }^{1}$ CARTWRight, G. E. The anemia of chronic disorders. Seminars in Hematology, v. 3, n. 4, p. 351-375, 1966.
} 
al. (2009) também atribuíram um mau prognóstico à presença da anemia em pacientes com linfoma, e observaram que cães com linfoma são mais comumentemente diagnosticados com anemia, considerando a natureza sistêmica da neoplasia, quando comparados com cães com osteossarcoma que, inicialmente, apresentam neoplasia localizada. A anemia foi mais observada em cães com linfoma acima de 10 anos de idade, enquanto nos cães com osteossarcoma essa correlação não existiu. Além disso, cães com linfoma apresentaram significativa diminuição na sobrevida, quando seus hematócritos apresentavam-se abaixo de $35 \%$.

Com relação ao metabolismo orgânico, incluindo aqui o eritrocitário, as reações aeróbicas culminam com a produção de espécies reativas do oxigênio mesmo em condições normais, consequentemente, há contínua necessidade de inativação dessas substâncias. Durante esse metabolismo, o oxigênio $\left(\mathrm{O}_{2}\right)$ sofre redução formando água $\left(\mathrm{H}_{2} \mathrm{O}\right)$. Para esse processo, substâncias intermediárias reativas são produzidas (próoxidantes), como radicais superóxido $\left(\mathrm{O}_{2}^{-{ }^{-}}\right)$, hidroperoxila $\left(\mathrm{HO}_{2}{ }^{\circ}\right)$ e hidroxila $(\mathrm{OH})$, e o peróxido de hidrogênio $\left(\mathrm{H}_{2} \mathrm{O}_{2}\right)$. A mitocôndria é a organela celular que normalmente realiza a redução completa do $\mathrm{O}_{2}$ (FERREIRA; MATSUBARA, 1997). Sabe-se que radicais livres em altas concentrações são deletérios para organismos vivos e podem induzir danos nos principais componentes celulares. Em concentrações equilibradas, radicais livres como o superóxido, desempenham papel regulatório importante como mediadores de processos de sinalização celular (MANDELKER, 2008). O equilíbrio entre pró-oxidantes e antioxidantes pode ser quebrado. Um desequilíbrio a favor dos próoxidantes e desfavorável aos antioxidantes potencialmente causa danos e é denominado estresse oxidativo (SIES, 1993; HALLIWELL; GUTTERIDGE, 1999; GHAFFARI, 2008; BUICO et al., 2009).

Causas comuns de estresse oxidativo incluem toxemias, infecções, hipóxia/isquemia, hiperglicemia, metabolismo de xenobióticos, hiperlipidemia, hiperproteinemia, inflamação, reações imunes, fagocitose, estado hipermetabólico e câncer. Além disso, células senescentes geralmente estão sob estresse oxidativo devido à falha da mitocôndria em produzir energia (ATP) suficiente para seu metabolismo. A maioria dos sistemas orgânicos está sob influência do metabolismo oxidativo e sua disfunção, o estresse oxidativo, representa um impacto direto com danos aos rins, coração e sistema circulatório, fígado, pâncreas, sistema nervoso central, intestinos, adrenais, medula óssea, pulmões e tireóide (MANDELKER, 2008). Segundo Halliwell e 
Gutteridge (1999), o estresse oxidativo ocorre pela diminuição de antioxidantes ou pelo aumento na produção de espécies reativas do oxigênio.

Segundo Vajdovich et al. (2005), baixas concentrações de radicais livres podem estimular o crescimento tumoral até que altos níveis de espécies reativas ou redução na atividade antioxidante resultem em morte celular. Mantovani et al. (2003) descreveram que pacientes com câncer apresentam níveis de espécies reativas do oxigênio no sangue mais altos que o grupo controle composto por pessoas saudáveis. Da mesma forma, aumento nos níveis de peroxidação lipídica em pacientes com cânceres gastrintestinal, cabeça, pescoço ou pulmão também foram observados em estudo de Mahdavi et al. (2009). Crianças com leucemia linfoblástica aguda apresentam aumento de substâncias reativas ao ácido tiobarbitúrico indicando aumento do estado oxidativo, sendo esta, segundo os autores, uma das causas da anemia nesses pacientes (GHOSH et al.,2005). Diversos estudos demonstram a influência do estresse oxidativo na carcinogênese de muitos tipos de tumores como de mama em mulheres e cadelas, de próstata em homens, leucemias e carcinoma epidermóide em cavidade oral de seres humanos (CHING et al., 2002; SZCZUBIAL et al., 2004; VALKO et al., 2004; KENNEDY et al., 2005; KUMARAGURUPARAN et al., 2005; LI et al., 2005; ELANGO; SAMUEL; CHINNAKKANNU, 2006; GÖNENÇ et al., 2006; VALKO et al., 2006).

As três principais defesas antioxidantes celulares enzimáticas são a superóxido dismutase (SOD), catalase e glutationa peroxidase (GPX) (SIES, 1993; ABOU-SEIF; RABIA; NASR, 2000; NEUMANN et al., 2003; BURAK ÇIMEN, 2008; MANDELKER, 2008; ZHAO et al., 2009). Estas enzimas antioxidantes localizadas no interior das células geralmente são capazes de eliminar e remover radicais livres, restabelecendo o equilíbrio celular (MANDELKER, 2008). Além disso, existem substâncias antioxidantes provenientes da dieta, conhecidas como antioxidantes secundários e que incluem a vitamina $\mathrm{E}$, vitamina $\mathrm{C}$, selênio, zinco, coenzima $\mathrm{Q} 10$, ácido alfa lipóico e bioflavonóides (carotenóides, polifenóis) (MANDELKER, 2008). Sabe-se, por exemplo, que o aumento da concentração intracelular de vitamina $\mathrm{C}$ pode exercer efeitos sobre o crescimento tumoral e capacidade de resposta ao estresse oxidativo associado com a quimioterapia e radioterapia, porém a suplementação não foi demonstrada como um benefício com relação à sobrevida ou remissão do tumor (AGUS; VERA; GOLDE, 1999). 
Após reações oxidativas, uma vez formado, o superóxido rapidamente sofre dismutação espontaneamente e/ou pela ação de enzimas superóxido dismutase, para formar $\mathrm{H}_{2} \mathrm{O}_{2}$ e $\mathrm{O}_{2}$. O peróxido de hidrogênio é removido por três mecanismos principais: (a) é catalisado por duas enzimas, catalase e glutationa peroxidase produzindo $\mathrm{H}_{2} \mathrm{O}$ e $\mathrm{O}_{2}$; (b) é convertido pela mieloperoxidase nos neutrófilos para ácido hipocloroso (HOCL), um produto fisiologicamente tóxico e forte oxidante que atua como agente bactericida em células fagocíticas; e (c) $\mathrm{H}_{2} \mathrm{O}_{2}$ é convertido em uma reação espontânea, catalisada pelo ferro $\left(\mathrm{Fe}^{2+}\right)$ denominada reação de Fenton.

Como os lipídeos possuem múltiplas duplas ligações, são importantes doadores de elétrons e também estão envolvidos na estabilização dos radicais livres, entretanto para isso, alterações ocorrem nas membranas celulares, compostas por lipídeos. A peroxidação lipídica está bem estabelecida como um mecanismo de dano celular tanto em plantas como animais. Este processo leva a perda de função e integridade da membrana celular e é amplamente aceito no envolvimento da patogenia de diversas doenças humanas (MORABITO et al., 2004). A presença aumentada de substâncias reativas ao ácido tiobarbitúrico é um parâmetro indicativo de estresse oxidativo, devido à peroxidação de ácidos graxos da membrana celular pelas espécies reativas do oxigênio. Estas substâncias são aldeídos, sendo o principal o malondialdeído (ESTERBAUER; CHEESEMAN, 1990).

Organismos vivos possuem mecanismos antioxidantes enzimáticos e químicos para controle dos oxidantes. Em algumas condições, aumento nos níveis de oxidante e diminuição de antioxidante anula a possibilidade dos mecanismos antioxidantes prevenirem os danos oxidativos (BUICO et al., 2009). Um método eficaz de se avaliar o estresse oxidativo é através da atividade antioxidante total. Os antioxidantes atuam em conjunto, portanto a avaliação de apenas um ou de alguns compostos pode ser falho (FIBACH; RACHMILEWITZ, 2008; BUICO et al., 2009). O estado antioxidante total considera a ação cumulativa de todos os antioxidantes presentes no plasma e fluidos corporais contra várias espécies reativas do oxigênio. Dentre as principais moléculas antioxidantes endógenas presentes no plasma, as principais são bilirrubina, ácido úrico e tióis de proteínas (SOMOGYI et al., 2007).

O estado antioxidante total encontra-se diminuído em pacientes com câncer. Esse fato deve-se provavelmente à utilização das vitaminas antioxidantes pelas células cancerígenas de forma mais eficiente que as células normais, ocasionando uma 
diminuição da concentração dos antioxidantes circulantes no plasma (LADAS et al., 2004). Entretanto, Mahdavi et al. (2009), observaram que pacientes com câncer de cabeça e pescoço apresentavam concentrações mais altas do estado antioxidante total. Acreditase que esse fato deve-se por uma regulação acima do normal das enzimas antioxidantes induzidas pelas espécies reativas do oxigênio em pacientes com câncer.

Uma importante classe de substâncias antioxidantes são as glutationas (ARMSTRONG et al., 2002; MANDELKER, 2008) que aparecem em suas formas oxidada (GSSG) e reduzida (GSH) e representam o tiol mais abundante no meio intracelular (85-90\%) (FERREIRA; MATSUBARA, 1997; GIUSTARINI et al., 2004; WU et al., 2004), sendo que o restante encontra-se distribuído em várias organelas, como mitocôndria, matriz celular e peroxissomos (WU et al., 2004).

Além da superóxido dismutase, catalase e glutationa peroxidase, outra classe de enzimas antioxidantes é representada pela glutationa-S-transferase e a enzima auxiliar, glutationa redutase, que utiliza nicotinamida-adenina-dinucleotídeo-fosfato (NADPH) para regenerar a glutationa reduzida a partir da glutationa oxidada (WU et al., 2004; BURAK ÇIMEN, 2008; GHAFFARI, 2008).

Wu et al. (2004) afirmam que a deficiência de glutationa contribui para o estresse oxidativo e que, além disso, pode ter papel fundamental no envelhecimento e patogênese de muitas doenças, entre elas o câncer.

Considerando as alterações do estresse oxidativo relacionadas à anemia, acreditase que a presença de processo inflamatório em pacientes com câncer pode ser responsável por mudanças fisiológicas, incluindo mudanças metabólicas que resultam em caquexia e, possivelmente, anemia. Mediadores inflamatórios, particularmente as citocinas (interleucina 6 [IL-6], fator de necrose tumoral alfa [TNF $\alpha$ ] e interleucina 1 beta [IL-1 $\beta]$ ) são atribuídas como responsáveis em induzir anorexia, náusea, êmese e alteração metabólica energética acentuada que ocorrem em pacientes com câncer avançado. A liberação de citocinas pró-inflamatórias em pacientes neoplásicos geralmente está associada com aumento na produção de espécies reativas do oxigênio (MACCIÒ et al., 2005).

Dallalio e Means (2003) observaram que as citocinas inflamatórias envolvidas na patogênese da anemia de doença crônica podem exercer seus efeitos na eritropoiese ao menos em parte pela modulação da resposta celular ao estresse oxidativo. 
A hemoglobina nas hemácias continuamente apresenta reações de oxirredução que, na presença do oxigênio, produzem o radical superóxido e peróxido de hidrogênio. Essas espécies reativas produzidas podem ser a fonte do estresse oxidativo, mas também podem exercer papéis funcionais importantes, como por exemplo, defesa oxidante contra o parasita da malária em seres humanos (RIFKIND et al., 2003).

Se grandes quantidades de pró-oxidantes tiverem acesso às hemácias, o que acontece por meio dos sistemas transportadores das membranas (GRUNE et al., 2000) ou se qualquer mecanismo de defesa contra essas substâncias for inadequado, pode ocorrer um aumento da oxidação da hemoglobina e/ou uma reação com outros constituintes das hemácias (como a membrana celular) causando dano celular irreversível (PAVRI et al., 1983). Também, nos eritrócitos, o desequilíbrio entre oxidantes e antioxidantes pode resultar em hemólise que é um dos mecanismos patogênicos da anemia no paciente com câncer (ZIMA et al., 1996).

Uma vez instalada a anemia, acaba por se formar um ciclo vicioso, uma vez que, segundo Grune et al. (2000), ao mesmo tempo em que os radicais livres predispõem à ocorrência da anemia, a hipóxia que se instala em decorrência da mesma é acompanhada por um aumento na produção de mais radicais livres, já que a hipóxia altera o metabolismo de catecolaminas aumentando sua produção e após exercerem seus efeito, são degradadas pela monoaminooxidase, em uma reação bioquímica que gera mais radicais livres. As modificações do metabolismo celular ocasionadas pela hipóxia são acompanhadas por nova liberação de mediadores inflamatórios, mantendo o processo.

Ghoti et al. (2007) observaram que as hemácias e plaquetas estão mais suscetíveis ao estresse oxidativo que os neutrófilos devido a baixa concentração da glutationa reduzida, assim, qualquer evento que promova a síntese de glutationa ou melhore sua utilização por seu efeito protetor, pode reduzir a formação de corpúsculos de Heinz (precipitado de hemoglobina devido oxidação da hemácia) e o dano eritrocitário (FETTMAN, 1991).

Neumann et al. (2003) observaram em camundongos que a perda da Prdx1 (membro da família de enzimas antioxidantes peroxiredoxina) causa anemia hemolítica fatal. Ao contrário, a ausência da catalase e glutationa peroxidase não ocasiona hemólise, enquanto a deficiência da superóxido dismutase mitocondrial causa moderada hemólise que não prejudica a sobrevida. Além disso, sugerem que a perda de função de Prdx1 pode 
contribuir para a tumorigênese, gerando principalmente neoplasias hematopoiéticas como o linfoma.

Ainda em relação à glutationa peroxidase, foram encontrados níveis mais elevados em pacientes com leucemia mielóide aguda e mielofibrose, enquanto sua atividade foi mais baixa em leucemias linfocíticas crônicas e mielóides crônicas (HOPKINS; TUDHOPE, 1973). Arruda et al. (1996) também observaram que a glutationa peroxidase estava significativamente mais baixa nas hemácias de pacientes com leucemia de células cabeludas ("hairy cell”). Entretanto, Gonzales et al. (1984) demonstraram que pacientes com leucemia mielóide aguda, leucemia linfocítica crônica, doença de Hodgkin, linfoma e vários cânceres viscerais não apresentaram alterações nas concentrações de glutationa peroxidase.

Lucas et al. (2008) avaliando cães com linfoma multicêntrico e o estado oxidante e antioxidante observaram que esses pacientes encontravam-se sob estresse oxidativo pelo aumento da peroxidação lipídica, assim como Winter et al. (2009) em seu estudo, concluíram que cães diagnosticados com linfoma multicêntrico estão sob estresse oxidativo em comparação aos cães normais (sadios), e que após o tratamento quimioterápico e com remissão completa, a homeostase de oxirredução está parcialmente restabelecida, ainda que seus valores não tenham retornado àqueles observados nos cães controle. No estudo de Winter et al. (2009), os valores de glutationa peroxidase e capacidade antioxidante total encontravam-se aumentados, devido a uma resposta compensatória ao estresse oxidativo, comprovado pelo aumento na peroxidação lipídica mensurado pelo malondialdeído.

Em estudo sobre estresse oxidativo e anemia, Lustoza (2004) avaliou cães com insuficiência renal crônica apresentando anemia e concluiu que esses pacientes estão sob forte estresse oxidativo, entretanto as hemácias desses cães ainda eram capazes de manter as defesas antioxidantes. Por outro lado, o aumento da peroxidação lipídica parece ter relação com a evolução da insuficiência renal e a intensidade da anemia. Santos (2005), em estudo com gatos, observou resultados similares àqueles obtidos no experimento com cães com insuficiência renal crônica e anemia.

Kumerova et al. (1998) observaram que pacientes portadores de hemoblastoses (policitemia vera, leucemia mielóide crônica, leucemia linfóide crônica) com ou sem anemia apresentavam diminuição das defesas antioxidantes e aumento da peroxidação lipídica nas hemácias. Diferenças foram observadas nas defesas antioxidantes entre 
hemácias normais e aquelas formadas a partir de clones de células leucêmicas, demonstrando uma função menos eficaz na anemia.

Novotna et al. (2009) demonstraram em seu estudo que pacientes com síndrome mielodisplásica de baixo risco apresentam um significativo aumento de dano oxidativo ao DNA das células da medula óssea, contribuindo assim, para a instabilidade genômica e progressão da doença.

Kaya et al. (2005) acreditam que mudanças nos parâmetros entre oxidantes e antioxidantes também ocorram pelo tratamento quimioterápico bem como pela remissão da doença. Para sobrevivência da célula é essencial manter a regulação de oxirredução no citosol (KAMERBEEK et al., 2007). Dürken et al. (2000) observaram que o estado antioxidante total encontrava-se diminuído após tratamento com altas doses de quimioterapia e radioquimioterapia que precediam transplantes de medula óssea.

Acredita-se ainda, que o estresse oxidativo possa ser um dos mecanismos envolvidos no fenômeno de resistência a múltiplas drogas quimioterápicas, que ocorre durante o tratamento de doenças linfoproliferativas (SHACTER et al., 2000; KANNAN, 2006) e que piora em muito o prognóstico do paciente. 


\section{OBJETIVOS}

Tendo em vista os mecanismos de estresse oxidativo que podem estar envolvidos na diminuição da meia vida das hemácias e, sendo essa diminuição um dos fatores que pode levar à anemia nos casos de linfoma, foram objetivos deste estudo determinar as concentrações eritrocitárias de glutationa reduzida e as atividades das enzimas antioxidantes eritrocitárias glutationa redutase, glutationa peroxidase, além de substâncias reativas ao ácido tiobarbitúrico e o estado antioxidante total em cães hígidos e com linfoma multicêntrico com e sem anemia, para avaliar a influência dos mecanismos oxidativos no desenvolvimento das anemias associadas a essa neoplasia. 


\section{MATERIAL E MÉTODO}

\subsection{ANIMAIS}

\subsubsection{Grupo controle (cães sadios)}

Este grupo foi constituído por 20 cães hígidos adultos (Quadro 1), domiciliados ou provenientes do Canil do Departamento de Clínica Médica da Faculdade de Medicina Veterinária e Zootecnia da Universidade de São Paulo, com idades variando de 1 a 12 anos, sendo 10 fêmeas e 10 machos, com ou sem definição racial, cuja anamnese e exames físico e complementares (hemograma e mensurações séricas de uréia, creatinina, alanina aminotransferase, fosfatase alcalina, proteína total e albumina) atestaram a higidez. 


\begin{tabular}{|c|c|c|c|c|}
\hline Número & $\begin{array}{c}\text { Nome do } \\
\text { Animal }\end{array}$ & $\begin{array}{l}\text { Idade } \\
\text { (anos) }\end{array}$ & Raça & Sexo \\
\hline 1 & Koda & 1 & Não definida & Macho \\
\hline 2 & Mery & 8 & Não definida & Fêmea \\
\hline 3 & Mel & 6 & Cocker Spaniel & Fêmea \\
\hline 4 & Odie & 1 & Fox Terrier & Macho \\
\hline 5 & Pandora & 5 & Pit Bull & Fêmea \\
\hline 6 & Vicky & 5 & Poodle & Fêmea \\
\hline 7 & Bob & 9 & Teckel & Macho \\
\hline 8 & Amy & 1 & Não definida & Fêmea \\
\hline 9 & Gaya & 6 & Não definida & Fêmea \\
\hline 10 & Bóris & 5 & Labrador & Macho \\
\hline 11 & Fly & 3 & $\begin{array}{l}\text { Pastor de } \\
\text { Shetland }\end{array}$ & Fêmea \\
\hline 12 & Preta & 8 & Não definida & Fêmea \\
\hline 13 & Logan & 1 & Bulldog Francês & Macho \\
\hline 14 & Bambam & 12 & Lhasa Apso & Macho \\
\hline 15 & Caramelo & & Não definida & Fêmea \\
\hline 16 & Bóris & 2 & Não definida & Macho \\
\hline 17 & Bili & 2 & Não definida & Macho \\
\hline 18 & Degas & 4 & $\begin{array}{c}\text { Golden } \\
\text { Retriever }\end{array}$ & Macho \\
\hline 19 & Meg & 1 & $\begin{array}{c}\text { Golden } \\
\text { Retriever }\end{array}$ & Fêmea \\
\hline 20 & Ralph & 4 & Teckel & Macho \\
\hline
\end{tabular}

Quadro 1 - Caracterização dos cães hígidos que compuseram o grupo controle - São Paulo $-2010$ 


\subsubsection{Grupo experimental (grupo de estudo)}

Foram avaliados 24 cães, 9 fêmeas e 15 machos, com idades entre 3 a 16 anos, com ou sem definição racial, com diagnóstico de linfoma multicêntrico, provenientes do atendimento do Serviço de Clínica Médica e de Pronto Atendimento Médico de Pequenos Animais, do Departamento de Clínica Médica / Hospital Veterinário da FMVZ-USP, Serviço de Oncologia Veterinária do "PROVET" de São Paulo-SP e do Serviço de Oncologia Veterinária do "SCAN - Saúde e Ciência Animal” de Campinas-SP.

Para a seleção dos animais foram considerados os dados de anamnese (linfonodomegalia generalizada, inexistência de outras neoplasias concomitantes ou em seu histórico, ausência de outras afecções simultâneas como nefropatias, hepatopatias e cardiopatias; não utilização de antiinflamatórios e/ou quimioterápicos antineoplásicos previamente) relatados pelos proprietários. Para a inclusão dos animais no grupo, foi realizada punção aspirativa por agulha fina, para exame citológico, de linfonodo cervical superficial ou poplíteo. Nos casos em que a citologia não foi conclusiva, os animais foram encaminhados para colheita de material para exame histopatológico. As avaliações citológicas e histopatológicas foram realizadas no Laboratório Clínico do Departamento de Clínica Médica e no Serviço de Patologia Animal do Departamento de Patologia / Hospital Veterinário da FMVZ-USP, respectivamente, de acordo com as técnicas rotineiramente empregadas.

Após confirmação do diagnóstico, colheu-se uma amostra de sangue para hemograma, avaliação renal e hepática. Após confirmação de inexistência de nefropatias e hepatopatias, os cães foram subdivididos em dois grupos: grupo experimental sem anemia (correspondendo a dez cães, três fêmeas e sete machos, com idades entre 4 a 12 anos, com e sem definição racial) e grupo experimental com anemia (correspondendo a 14 cães, seis fêmeas e oito machos, com idades entre 3 a 16 anos, com e sem definição racial). Foram considerados anêmicos os cães que apresentaram valores de hematócrito e hemoglobina inferiores a $37 \%$ e $12 \mathrm{~g} \%$, respectivamente. Em todos os animais diagnosticados com linfoma multicêntrico foram realizados exames radiográficos do tórax e ultra-sonografia 
abdominal, além do mielograma para o estadiamento clínico da neoplasia segundo a Organização Mundial da Saúde - OMS.

Os cães de cada grupo estão caracterizados nos quadros 2 e 3 , respectivamente.

\begin{tabular}{|cccccc|}
\hline Número & $\begin{array}{c}\text { Nome do } \\
\text { Animal }\end{array}$ & $\begin{array}{c}\text { Idade } \\
\text { (anos) }\end{array}$ & Raça & Sexo & $\begin{array}{c}\text { Estadiamento } \\
\text { Clínico }\end{array}$ \\
\hline 1 & Hulk & 6 & Pit Bull & Macho & IVb \\
2 & Spock & 5 & Pastor & Macho & IVb \\
& & Alemão & & \\
3 & Faísca & 4 & Pit Bull & Macho & Va \\
4 & Tico & 6 & Cocker & Macho & IVa \\
& & & Spaniel & & Vb \\
5 & Pirata & 12 & Não definida & Macho & IVa \\
7 & Bóris & 8 & Labrador & Macho & IVa \\
8 & Filet & 6 & Fox Terrier & Macho & IVa \\
9 & Jade & 10 & Pastor & Fêmea & Va \\
10 & & & Alemão & & IVa \\
\hline
\end{tabular}

Quadro 2 - Caracterização dos cães com linfoma multicêntrico que compuseram o grupo experimental sem anemia - São Paulo - 2010 


\begin{tabular}{|c|c|c|c|c|c|}
\hline Número & $\begin{array}{c}\text { Nome do } \\
\text { Animal }\end{array}$ & $\begin{array}{l}\text { Idade } \\
\text { (anos) }\end{array}$ & Raça & Sexo & $\begin{array}{l}\text { Estadiamento } \\
\text { Clínico }\end{array}$ \\
\hline 1 & Laika & 10 & $\begin{array}{c}\text { Fila } \\
\text { Brasileiro }\end{array}$ & Fêmea & $\mathrm{IVb}$ \\
\hline 2 & Fred & 14 & Poodle & Macho & $\mathrm{IVb}$ \\
\hline 3 & Fred & 7 & Teckel & Macho & $\mathrm{IVb}$ \\
\hline 4 & Otto & 7 & Bernese & Macho & $\mathrm{IVb}$ \\
\hline 5 & Hooligan & 8 & Bull Terrier & Macho & IIIa \\
\hline 6 & Medilaio & 16 & $\begin{array}{c}\text { Pastor } \\
\text { Alemão }\end{array}$ & Macho & $\mathrm{IVb}$ \\
\hline 7 & Leão & 12 & Não definida & Macho & $\mathrm{IVb}$ \\
\hline 8 & Maisa & 10 & Setter Inglês & Fêmea & $\mathrm{Vb}$ \\
\hline 9 & Chitara & 12 & Não definida & Fêmea & $\mathrm{IVb}$ \\
\hline 10 & Romeu & 4 & Não definida & Macho & $\mathrm{Vb}$ \\
\hline 11 & Boni & 7 & $\begin{array}{l}\text { Cocker } \\
\text { Spaniel }\end{array}$ & Fêmea & IVa \\
\hline 12 & Lion & 3 & Rottweiller & Macho & $\mathrm{IVb}$ \\
\hline 13 & Úrsula & 7 & Rottweiller & Fêmea & $\mathrm{IVb}$ \\
\hline 14 & Sussa & 8 & Shar-Pei & Fêmea & $\mathrm{Va}$ \\
\hline
\end{tabular}

Quadro 3 - Caracterização dos cães com linfoma multicêntrico que compuseram o grupo experimental com anemia - São Paulo - 2010

De cada animal, sadio ou doente, após jejum alimentar de aproximadamente 8 horas, colheu-se uma amostra de $20,0 \mathrm{~mL}$ de sangue por punção venosa jugular, radial ou safena; sendo 4,0 mL de sangue acondicionados em dois frascos contendo $\mathrm{Na}_{2} \mathrm{EDTA}$, sendo um deles destinado a execução do hemograma e contagem de plaquetas, e o outro para separação de hemácias, para determinação de glutationa reduzida. No momento da colheita foi realizada a confecção do esfregaço sanguíneo para realização da contagem diferencial de leucócitos. Outros 10,0 mL foram acondicionados em um frasco contendo heparina sódica, para separação dos eritrócitos do plasma para a determinação da atividade das enzimas eritrocitárias glutationa peroxidase e glutationa redutase, além das substâncias reativas ao ácido tiobarbitúrico. O restante do sangue $(6,0 \mathrm{~mL})$, mantido em 
frasco siliconizado sem anticoagulante, foi centrifugado e o soro estocado para a determinação do estado antioxidante total e demais provas laboratoriais (uréia, creatinina, alanina aminotransferase, fosfatase alcalina, proteína total e albumina).

\subsection{EXAMES COMPLEMENTARES}

\subsubsection{Hemograma}

A contagem das células sanguíneas e plaquetas foram determinadas em contador automático $\mathrm{ABC}$ Vet - Horiba, ABX, de uso veterinário. A contagem diferencial dos leucócitos e a avaliação morfológica de hemácias e leucócitos foram realizadas em esfregaço sanguíneo "in natura", corado pelo corante de Rosenfeld. O hemograma foi realizado após o diagnóstico e antes do início do tratamento quimioterápico.

\subsubsection{Bioquímica sérica}

As provas laboratoriais referentes à avaliação do fígado e rins foram realizadas utilizando-se kits comerciais em analisador bioquímico automático. 


\subsubsection{Mielograma}

Os animais foram submetidos à anestesia geral, recebendo como medicação préanestésica a acepromazina a $0,2 \%$ (na dose de $0,05 \mathrm{mg} / \mathrm{Kg}$ ) e anestesiados com propofol (na dose de 5,0 mg/Kg). O material foi colhido por punção aspirativa da medula óssea, realizada na crista ilíaca ou esterno, utilizando-se agulhas comerciais descartáveis ou específicas para esse procedimento. Os esfregaços do material obtido foram feitos no momento da colheita e, posteriormente, submetidos à coloração pela técnica de Rosenfeld e examinados em microscópio óptico.

\subsubsection{Exames de imagem}

Foram realizadas radiografias torácicas nas posições látero-lateral e ventro-dorsal, de acordo com os métodos utilizados na rotina do Serviço de Diagnóstico por Imagem do Hospital Veterinário da Faculdade de Medicina Veterinária e Zootecnia da Universidade de São Paulo e ultra-sonografia abdominal, utilizando-se transdutores de 5,0 e 7,5 MHz, de acordo com o porte e peso dos animais.

\subsection{EXAMES ESPECÍFICOS}

\subsubsection{Determinação intraeritrocitária de glutationa reduzida (GSH)}

A determinação da glutationa reduzida $(\mathrm{GSH})$ no sangue foi realizada pelo método do ácido ditionitrobenzóico (DTNB), descrito por Beutler et al. (1963). Em 200 $\mu \mathrm{L}$ de sangue total foram adicionados $1,8 \mathrm{~mL}$ de água purificada para obter o hemolisado. Em seguida foram acrescentados $3,0 \mathrm{~mL}$ de solução precipitante $(1,67 \mathrm{~g}$ de ácido 
metafosfórico glacial; 0,20 g de EDTA; 30,0 g de NaCl; em $100 \mathrm{~mL}$ de água purificada). Esta mistura permaneceu em repouso por 5 minutos e então foi centrifugada durante 5 minutos a 1900 G. Da amostra, $200 \mu \mathrm{L}$ do sobrenadante foram armazenados em tubos foscos, que foram estocados a $80^{\circ} \mathrm{C}$ negativos para posterior determinação de GSH.

Após descongelamento, acrescentou-se aos $200 \mu \mathrm{L}$ do sobrenadante $0,8 \mathrm{~mL}$ de solução fosfato (42,6 g de NaHPO em $1000 \mathrm{~mL}$ de água purificada). Esta solução foi transferida para cubetas de leitura no espectrofotômetro, onde foram acrescentados 100 $\mu \mathrm{L}$ de ácido ditionitrobenzóico (1,0 g de citrato de sódio; 40,0 mg de DTNB em $100 \mathrm{~mL}$ de água purificada) e a leitura efetuada em até 30 segundos. A absorbância foi mensurada por espectrofotometria em comprimento de onda de $412 \mathrm{\eta m}$, e posteriormente calculada a concentração de GSH.

Os padrões de GSH utilizados para a confecção da curva de calibração apresentavam concentrações de 5, 10, 15, 20, 25 e $50 \mathrm{mg} / \mathrm{dL}$.

A concentração de GSH foi calculada com base na equação de reta obtida da curva das soluções padrão e das leituras de densidade óptica das mesmas. O resultado final foi expresso em $\mathrm{mg} / \mathrm{dL}$.

Todas as determinações de GSH foram realizadas num período máximo de três meses após a colheita das amostras.

\subsubsection{Determinação intraeritrocitária de glutationa peroxidase (GPX)}

A atividade da glutationa peroxidase (GPX) foi determinada utilizando-se kits comerciais (Ransel 505 - RANDOX Laboratories, Crumlin/UK) adequados para uso em analisador bioquímico automático (Liasys ${ }^{\circledR}$ AMS, Rome, Italy ou Labmax $240^{\circledR}$ Tokyo Boeki Ltd., Tokyo, Japan). O método baseia-se na reação em que a glutationa peroxidase catalisa a oxidação da glutationa reduzida por um hidroperóxido. $\mathrm{Na}$ presença de glutationa redutase e NADPH, a glutationa oxidada é imediatamente convertida à forma reduzida com a oxidação concomitante do $\mathrm{NADPH}$ em $\mathrm{NADH}^{+}$, a diminuição da concentração do NADPH foi mensurada pela absorbância em comprimento de onda de 340 ๆm (PAGLIA; VALENTINE, 1967). 
Para a determinação desta enzima, a papa de hemácias (obtida da centrifugação a $1900 \mathrm{G}$, a $4{ }^{\circ} \mathrm{C}$ por 15 minutos do sangue em tubo contendo heparina sódica, seguida pela lavagem dos eritrócitos com solução salina tamponada) previamente armazenada em microtubo fosco foi descongelada em banho em água a $30{ }^{\circ} \mathrm{C}$. Em seguida adicionou-se $400 \mu \mathrm{L}$ de água ultrapura a $4^{\circ} \mathrm{C}$. Após agitação no vórtex, os microtubos foram mantidos em geladeira durante 10 minutos e em seguida, centrifugados a $380 \mathrm{G}$ durante 2 minutos. O sobrenadante foi diluído 100 vezes em diluente fornecido pelo fabricante do kit antes da análise. Determinou-se a concentração de hemoglobina do hemolisado, com o resultado final expresso em unidades de enzima por grama de hemoglobina (U/g Hb).

As determinações de GPX foram realizadas num período máximo de 30 dias após a colheita da amostra.

\subsubsection{Determinação intraeritrocitária de glutationa redutase (GR)}

A atividade da glutationa redutase foi determinada utilizando-se kits comerciais (GR 2368 - RANDOX Laboratories, Crumlin/UK) adaptados para uso em analisador bioquímico automático (Liasys ${ }^{\circledR}$ AMS, Rome, Italy ou Labmax $240{ }^{\circledR}$ Tokyo Boeki Ltd., Tokyo, Japan). O método baseia-se na reação em que a glutationa redutase catalisa a redução da glutationa oxidada em presença de NADPH, que é oxidado. A diminuição da concentração de NADPH foi mensurada pela absorbância em comprimento de onda de 340 ๆm (MELISSINOS et al., 1981).

Para a determinação da glutationa redutase, o hemolisado (obtido após lavagem dos eritrócitos para determinação de GPX e adicionado água ultrapura a $4{ }^{\circ} \mathrm{C}$, mantido em repouso por 15 minutos sob mesma temperatura e centrifugado a $1900 \mathrm{G}$ por 15 minutos) previamente estocado em microtubos, foi descongelado em banho em água a $30{ }^{\circ} \mathrm{C}$ e centrifugado em centrífuga para microtubos a $380 \mathrm{G}$ durante 2 minutos. Diluiu-se o sobrenadante 20 vezes em solução salina antes da análise. Foi determinada a 
concentração de hemoglobina do hemolisado, com o resultado final expresso em unidades de enzima por grama de hemoglobina (U/g Hb).

As determinações de GR foram realizadas num período máximo de 30 dias após a colheita da amostra.

\subsubsection{Determinação da concentração plasmática das substâncias reativas ao ácido tiobarbitúrico (TBARS)}

Realizou-se a determinação das concentrações plasmáticas das substâncias reativas ao ácido tiobarbitúrico (TBARS) pelo método do ácido tiobarbitúrico conforme descrito por Esterbauer e Cheeseman (1990), em que se promove a reação do malondialdeído e outros aldeídos com o ácido tiobarbitúrico em meio aquecido, submetendo-se, após, ao resfriamento rápido e a mensuração da absorbância, realizada em comprimento de onda de $535 \mathrm{\eta m}$.

Primeiramente, acrescentou-se $500 \mu \mathrm{L}$ de plasma da amostra (obtido após centrifugação a $1900 \mathrm{G}$, a $4{ }^{\circ} \mathrm{C}$ por 15 minutos do sangue em tubo contendo heparina sódica) ou padrão a $1000 \mu \mathrm{L}$ de ácido tricloroacético a 10\%; em seguida a amostra foi homogeneizada no vórtex e a mistura centrifugada a $1900 \mathrm{G}$ durante 15 minutos. Após a centrifugação foram pipetados $750 \mu \mathrm{L}$ do sobrenadante e adicionados a $750 \mu \mathrm{L}$ de ácido tiobarbitúrico $1 \%$ dissolvido em solução de hidróxido de sódio a $0,05 \mathrm{M}$. O mesmo procedimento foi realizado para os padrões e para o branco de reação que utiliza água purificada. Em seguida, todos os tubos foram colocados em banho de água fervente $\left(100^{\circ} \mathrm{C}\right)$ durante 10 minutos e resfriados em água gelada durante 5 minutos. A leitura da densidade óptica foi realizada em comprimento de onda de 532 ๆm.

Os padrões de malondialdeído bisdimetil utilizados para confecção da curva de calibração apresentavam concentrações de 1, 5 e 10 momolar. 
A concentração de TBARS das amostras foi calculada com base na equação de reta obtida da curva das soluções padrão e das leituras de densidade óptica das mesmas. O resultado final foi expresso em $\mu \mathrm{mol} / \mathrm{L}$.

As determinações de TBARS foram realizadas num período máximo de três meses após a colheita das amostras.

\subsubsection{Determinação do estado antioxidante total (TAS)}

A avaliação do estado antioxidante total (TAS) possibilita a avaliação do sistema antioxidante integrado que cerca todos os componentes biológicos com atividade antioxidante.

Foi avaliado no soro sanguíneo dos animais (obtido após centrifugação a 1900 G, a $4{ }^{\circ} \mathrm{C}$ por 15 minutos do sangue em frasco siliconizado sem anticoagulante), utilizandose kits comerciais (Total antioxidant status - NX2332 - RANDOX Laboratories, Crumlin/UK) adaptados para uso em analisador bioquímico automático (Liasys ${ }^{\circledR}$ AMS, Rome, Italy ou Labmax $240^{\circledR}$ Tokyo Boeki Ltd., Tokyo, Japan). O ácido sulfônico 2.2'azino dietil-benzotiazolínico (ABTS) é incubado com a peroxidase (metamioglobina) e peróxido de hidrogênio para produzir o cátion ABTS reduzido. Este é relativamente estável e apresenta coloração azul-esverdeada, o qual é medido a 600 ๆm. As substâncias antioxidantes presentes na amostra impedem a reação, gerando uma redução na intensidade de cor proporcional à concentração de antioxidantes totais.

O resultado final foi expresso em $\mu \mathrm{mol} / \mathrm{L}$.

As determinações de TAS foram realizadas em um período máximo de seis meses após a colheita das amostras. 


\subsection{ANÁLISE ESTATÍSTICA}

As análises estatísticas foram realizadas com auxílio de programa estatístico Graph Pad Instat, versão 3.01 e Graph Pad Prism, versão 5.03, segundo Petrie e Watson (1999).

Os dados foram, inicialmente, testados quanto à distribuição normal, utilizando-se o teste de Kolmogorov-Smirnov. Para se verificar a existência ou não de diferença significativa entre os cães hígidos e aqueles com linfoma multicêntrico, foram utilizados testes estatísticos paramétricos ou não, de acordo com a distribuição apresentada pelos resultados.

O teste de análise de variância (ANOVA) foi utilizado na análise dos resultados de glutationa reduzida, glutationa peroxidase e estado antioxidante total, seguido pela comparação dos dados pelo teste de Student-Newman-Keuls (PETRIE; WATSON, 1999). O teste ANOVA não paramétrico (Kruskal-Wallis) foi utilizado para análise dos valores de glutationa redutase e substâncias reativas ao ácido tiobarbitúrico, seguido pela comparação dos dados pelo teste de Dunn.

Quando comparados os grupos controle e de cães doentes (linfoma com e sem anemia) foi utilizado o teste $t$ de Student não pareado para glutationa reduzida, glutationa peroxidase e estado antioxidante total. O teste não paramétrico de Mann-Whitney foi utilizado para substâncias reativas ao ácido tiobarbitúrico e glutationa redutase. 
Os valores individuais, mínimo e máximo, a média, mediana e o desvio padrão da média do hematócrito, das concentrações eritrocitárias de glutationa reduzida, glutationa peroxidase e glutationa redutase; das concentrações plasmáticas de substâncias reativas ao ácido tiobarbitúrico; e do estado antioxidante total dos cães do grupo controle (sadios), cães com linfoma multicêntrico e sem anemia e cães com linfoma multicêntrico e com anemia estão demonstrados nas tabelas 1,2 e 3 respectivamente.

Foram aceitos como estatisticamente significativos valores de $\mathrm{p}<0,05$ (Tabela 4).

$\mathrm{Na}$ avaliação dos cães do grupo controle (sadios) e agrupando os animais com linfoma multicêntrico com e sem anemia (doentes), utilizando o teste t de Student, foram observadas diferenças significativas nos valores eritrocitários de glutationa reduzida, glutationa peroxidase e estado antioxidante total $(\mathrm{p}=0,0012 ; \mathrm{p}=0,0016$ e $\mathrm{p}<0,001$ respectivamente). Não foram observadas diferenças significativas, utilizando o teste de Mann-Whitney, entre os mesmos grupos na avaliação dos valores eritrocitários de glutationa redutase e substâncias reativas ao ácido tiobarbitúrico $(\mathrm{p}=0,0678$ e $\mathrm{p}=0,6714$ respectivamente).

Não foram observadas diferenças significativas entre o grupo de cães sadios (controle) e o grupo experimental de cães com linfoma multicêntrico e sem anemia com relação aos valores eritrocitários de glutationa reduzida $(\mathrm{p}>0,05)$. Entretanto, foi observada diferença significativa entre o grupo controle (sadios) e o grupo experimental de cães com linfoma multicêntrico e com anemia $(p<0,001)$ e entre os animais com linfoma com e sem anemia $(\mathrm{p}<0,05)$.

Foi observada diferença significativa na análise da concentração de glutationa peroxidase entre os cães do grupo controle (sadios) e grupo experimental com linfoma multicêntrico e com anemia $(p<0,01)$ e entre o grupo controle e cães com linfoma e sem anemia $(p<0,05)$. Não foram significativas as diferenças entre os grupos experimentais com linfoma e com anemia e com linfoma e sem anemia $(p>0,05)$.

Não houve diferença significativa na avaliação das concentrações eritrocitárias de glutationa redutase e substâncias reativas ao ácido tiobarbitúrico entre o grupo controle (sadios), grupo experimental com linfoma multicêntrico e com anemia e grupo 
experimental com linfoma multicêntrico e sem anemia $(p=0,1833$ e $p=0,823$ respectivamente).

Houve diferença significativa no estado antioxidante total entre o grupo controle (sadios) e grupo experimental com linfoma multicêntrico e com anemia; e entre o grupo controle (sadios) e grupo experimental com linfoma multicêntrico e sem anemia ( $\mathrm{p}<$ 0,001 e $\mathrm{p}<0,001$ respectivamente). Não houve diferença significativa quando comparados o grupo experimental com linfoma multicêntrico e sem anemia e o grupo experimental com linfoma multicêntrico e com anemia.

Apesar de estatisticamente não significativo, no caso da glutationa redutase, os cães com linfoma multicêntrico e com anemia apresentaram valores menores (média de $6,11 \mathrm{U} / \mathrm{g} \mathrm{Hb}$ ) do que os cães sadios (média de 6,82 U/g Hb) e cães com linfoma multicêntrico e sem anemia (média de 6,31 U/g Hb). Com relação às concentrações plasmáticas de substâncias reativas ao ácido tiobarbitúrico, os valores no grupo experimental com linfoma multicêntrico e com anemia foram maiores (média de 0,94 $\mu \mathrm{mol} / \mathrm{L}$ ) do que no grupo controle (média de $0,81 \mu \mathrm{mol} / \mathrm{L}$ ) e grupo experimental com linfoma multicêntrico e sem anemia (média de $0,71 \mu \mathrm{mol} / \mathrm{L}$ ).

Nos gráficos 1, 2, 3, 4, 5 e 6 encontram-se representados os valores das medianas e de mínimo e máximo do hematócrito, das concentrações eritrocitárias de glutationa reduzida, glutationa peroxidase, glutationa redutase; das concentrações plasmáticas de substâncias reativas ao ácido tiobarbitúrico e estado antioxidante total.

O estudo da relação (grupo controle e grupo doente) entre o hematócrito e as análises de glutationa reduzida e glutationa peroxidase mostraram correlação positiva, porém não significativa $(\mathrm{r}=0,14$ e $\mathrm{r}=0,18$ respectivamente; $\mathrm{p}=0,35$ e $\mathrm{p}=0,24$ respectivamente). Foi detectada correlação positiva significativa entre os valores de hematócrito e estado antioxidante total $(\mathrm{r}=0,43 ; \mathrm{p}=0,0031)$. Correlações não significativas foram observadas entre os valores de hematócrito e glutationa redutase $(\mathrm{r}=$ - 0,08; $\mathrm{p}=0,5961)$; e hematócrito e substâncias reativas ao ácido tiobarbitúrico $(\mathrm{r}=$ $0,28 ; p=0,0646)$. As relações encontram-se representadas nos gráficos 7, 8, 9, 10 e 11 .

No estudo da relação (grupo controle e grupo doente) entre glutationa reduzida e glutationa redutase; e glutationa reduzida e estado antioxidante total foram observadas correlações positivas significativas $(r=0,34 ; p=0,0229$ e $r=0,58 ; p<0,0001$ respectivamente). Correlação positiva, porém não significativa foi observada entre 
glutationa reduzida e substâncias reativas ao ácido tiobarbitúrico $(\mathrm{r}=0,02 ; \mathrm{p}=0,8671)$. As relações estão demonstradas nos gráficos 12, 13 e 14 .

Tabela 1 - Hematócrito (Ht), valores individuais, mínimo e máximo (Mín-Máx), médias, medianas e desvios padrão da média (DP) da glutationa reduzida (GSH), glutationa peroxidase (GPX), glutationa redutase (GR), substâncias reativas ao ácido tiobarbitúrico (TBARS) e estado antioxidante total (TAS) de cães do grupo controle (sadios) - São Paulo - 2010

\begin{tabular}{|c|c|c|c|c|c|c|}
\hline Animal & $\begin{array}{l}\text { Ht } \\
(\%)\end{array}$ & $\begin{array}{c}\text { GSH } \\
\text { (mg/dL) }\end{array}$ & $\begin{array}{c}\text { GPX } \\
\text { (U/g Hb) }\end{array}$ & $\begin{array}{c}\text { GR } \\
\text { (U/g Hb) }\end{array}$ & $\begin{array}{c}\text { TBARS } \\
(\mu \mathrm{mol} / \mathrm{L})\end{array}$ & $\begin{array}{c}\text { TAS } \\
(\mu \mathrm{mol} / \mathrm{L})\end{array}$ \\
\hline 1 & 53 & 35,71 & 13,91 & 7,27 & 0,62 & 0,86 \\
\hline 2 & 55 & 50,85 & 11,28 & 7,37 & 0,34 & 0,77 \\
\hline 3 & 63 & 39,14 & 9,64 & 5,88 & 0,34 & 0,97 \\
\hline 4 & 46 & 37,50 & 4,74 & 7,74 & 0,66 & 0,86 \\
\hline 5 & 43 & 36,94 & 8,74 & 6,63 & 0,61 & 0,90 \\
\hline 6 & 48 & 30,55 & 9,19 & 7,88 & 1,02 & 0,92 \\
\hline 7 & 52 & 64,44 & 12,03 & 7,92 & 1,12 & 0,93 \\
\hline 8 & 49 & 40,00 & 7,96 & 6,61 & 1,17 & 0,88 \\
\hline 9 & 57 & 44,44 & 10,18 & 7,17 & 1,13 & 0,93 \\
\hline 10 & 56 & 40,27 & 10,22 & 7,61 & 1,02 & 1,09 \\
\hline 11 & 40 & 46,38 & 8,69 & 7,06 & 0,82 & 1,02 \\
\hline 12 & 47 & 29,72 & 8,70 & 7,38 & 0,87 & 0,86 \\
\hline 13 & 40 & 25,55 & 14,39 & 7,92 & 0,71 & 0,91 \\
\hline 14 & 48 & 29,44 & 8,77 & 7,26 & 0,56 & 0,93 \\
\hline 15 & 50 & 38,05 & 10,01 & 6,67 & 0,66 & 0,85 \\
\hline 16 & 56 & 35,00 & 10,01 & 6,37 & 0,92 & 0,84 \\
\hline 17 & 49 & 43,88 & 9,71 & 5,88 & 1,02 & 1,02 \\
\hline 18 & 45 & 27,35 & 10,43 & 4,35 & 1,18 & 0,78 \\
\hline 19 & 42 & 27,35 & 8,73 & 4,69 & 0,79 & 0,56 \\
\hline 20 & 47 & 40,00 & 12,03 & 6,74 & 0,56 & 0,69 \\
\hline Mín-Máx & $40-63$ & $25,55-64,44$ & $4,74-14,39$ & $4,35-7,92$ & $0,34-1,18$ & $0,56-1,09$ \\
\hline Média & 49 & 38,13 & 9,97 & 6,82 & 0,81 & 0,87 \\
\hline Mediana & 48 & 37,77 & 9,86 & 7,12 & 0,80 & 0,89 \\
\hline DP & 6 & 9,22 & 2,12 & 0,99 & 0,26 & 0,11 \\
\hline
\end{tabular}


Tabela 2 - Hematócrito (Ht), valores individuais, mínimo e máximo (Mín-Máx), médias, mediana e desvios padrão da média (DP) da glutationa reduzida (GSH), glutationa peroxidase (GPX), glutationa redutase (GR), substâncias reativas ao ácido tiobarbitúrico (TBARS) e estado antioxidante total (TAS) de cães do grupo experimental com linfoma multicêntrico e sem anemia - São Paulo 2010

\begin{tabular}{|c|c|c|c|c|c|c|}
\hline Animal & $\begin{array}{l}\text { Ht } \\
(\%)\end{array}$ & $\begin{array}{c}\text { GSH } \\
(\mathrm{mg} / \mathrm{dL})\end{array}$ & $\begin{array}{c}\text { GPX } \\
\text { (U/g Hb) }\end{array}$ & $\begin{array}{c}\text { GR } \\
\text { (U/g Hb) }\end{array}$ & $\begin{array}{l}\text { TBARS } \\
(\mu \mathrm{mol} / \mathrm{L})\end{array}$ & $\begin{array}{c}\text { TAS } \\
(\mu \mathrm{mol} / \mathrm{L})\end{array}$ \\
\hline 1 & 53 & 44,28 & 11,74 & 6,85 & 0,90 & 0,75 \\
\hline 2 & 45 & 42,28 & 10,02 & 5,75 & 0,96 & 0,64 \\
\hline 3 & 39 & 5,20 & 10,38 & 4,47 & 0,55 & 0,48 \\
\hline 4 & 46 & 4,40 & 3,27 & 5,18 & 0,32 & 0,67 \\
\hline 5 & 39 & 34,07 & 10,73 & 4,76 & 1,23 & 0,51 \\
\hline 6 & 49 & 34,07 & 7,95 & 6,26 & 0,30 & 0,48 \\
\hline 7 & 45 & 43,70 & 7,01 & 5,28 & 0,18 & 0,60 \\
\hline 8 & 52 & 39,25 & 4,31 & 5,56 & 0,30 & 0,53 \\
\hline 9 & 39 & 31,66 & 10,60 & 9,77 & 1,23 & 0,73 \\
\hline 10 & 40 & 41,66 & 3,59 & 9,25 & 1,17 & 0,89 \\
\hline Mín-Máx & $39-53$ & $4,40-44,28$ & $3,27-11,74$ & $4,47-9,77$ & $0,18-1,23$ & $0,48-0,89$ \\
\hline Média & 44 & 32,06 & 7,96 & 6,31 & 0,71 & 0,62 \\
\hline Mediana & 45 & 36,66 & 8,98 & 5,66 & 0,73 & 0,62 \\
\hline DP & 5 & 15,01 & 3,24 & 1,82 & 0,42 & 0,13 \\
\hline
\end{tabular}


Tabela 3 - Hematócrito (Ht), valores individuais, mínimo e máximo (Mín-Máx), médias, mediana e desvios padrão da média (DP) da glutationa reduzida (GSH), glutationa peroxidase (GPX), glutationa redutase (GR), substâncias reativas ao ácido tiobarbitúrico (TBARS) e estado antioxidante total (TAS) de cães do grupo experimental com linfoma multicêntrico e anemia - São Paulo - 2010

\begin{tabular}{|c|c|c|c|c|c|c|}
\hline Animal & $\begin{array}{l}\text { Ht } \\
(\%)\end{array}$ & $\begin{array}{c}\text { GSH } \\
(\mathrm{mg} / \mathrm{dL})\end{array}$ & $\begin{array}{c}\text { GPX } \\
\text { (U/g Hb) }\end{array}$ & $\begin{array}{c}\text { GR } \\
\text { (U/g Hb) }\end{array}$ & $\begin{array}{c}\text { TBARS } \\
(\mu \mathrm{mol} / \mathrm{L})\end{array}$ & $\begin{array}{c}\text { TAS } \\
(\mu \mathrm{mol} / \mathrm{L})\end{array}$ \\
\hline 1 & 31 & 17,71 & 10,34 & 9,20 & 0,79 & 0,68 \\
\hline 2 & 28 & 26,85 & 8,90 & 9,66 & 1,02 & 0,72 \\
\hline 3 & 35 & 42,57 & 10,55 & 6,63 & 0,85 & 0,68 \\
\hline 4 & 27 & 25,42 & 8,45 & 5,18 & 1,93 & 0,64 \\
\hline 5 & 30 & 27,14 & 7,06 & 4,73 & 0,96 & 0,85 \\
\hline 6 & 28 & 4,80 & 4,88 & 3,82 & 0,18 & 0,43 \\
\hline 7 & 34 & 10,80 & 4,56 & 5,13 & 0,41 & 0,43 \\
\hline 8 & 24 & 8,80 & 2,67 & 6,32 & 0,41 & 0,57 \\
\hline 9 & 25 & 16,40 & 6,22 & 1,68 & 0,32 & 0,53 \\
\hline 10 & 22 & 19,63 & 6,09 & 7,61 & 2,46 & 0,61 \\
\hline 11 & 27 & 37,77 & 2,90 & 5,80 & 0,74 & 0,64 \\
\hline 12 & 28 & 15,55 & 9,78 & 5,74 & 0,06 & 0,42 \\
\hline 13 & 18 & 25,92 & 8,38 & 6,28 & 1,97 & 0,57 \\
\hline 14 & 32 & 20,74 & 6,39 & 7,75 & 1,04 & 0,67 \\
\hline Mín-Máx & $18-35$ & $4,80-42,57$ & $2,67-10,55$ & $1,68-9,66$ & $0,06-2,46$ & $0,42-0,85$ \\
\hline Média & 27 & 21,43 & 6,94 & 6,11 & 0,94 & 0,60 \\
\hline Mediana & 28 & 20,18 & 6,72 & 6,04 & 0,82 & 0,62 \\
\hline DP & 4 & 10,23 & 2,58 & 2,08 & 0,72 & 0,12 \\
\hline
\end{tabular}


Tabela 4 - Valores de significância das concentrações eritrocitárias de glutationa reduzida (GSH), glutationa peroxidase (GPX), glutationa redutase (GR), substâncias reativas ao ácido tiobarbitúrico (TBARS) e estado antioxidante total (TAS) entre os grupos controle (sadios), grupo experimental com linfoma multicêntrico e sem anemia, grupo experimental com linfoma multicêntrico e com anemia e grupo experimental doente (com linfoma multicêntrico com e sem anemia) - São Paulo - 2010

\begin{tabular}{ccccc}
\hline Parâmetro & $\begin{array}{c}\text { Controle } \mathbf{x} \\
\text { Não Anêmico }\end{array}$ & $\begin{array}{c}\text { Controle } \mathbf{c} \\
\text { Anêmico }\end{array}$ & $\begin{array}{c}\text { Anêmico } \mathbf{c} \\
\text { Não Anêmico }\end{array}$ & $\begin{array}{c}\text { Controle } \mathbf{x} \\
\text { Doente }\end{array}$ \\
\hline GSH & $\mathrm{p}>0,05$ & $\mathrm{p}<0,001$ & $\mathrm{p}<0,05$ & $\mathrm{p}=0,0012$ \\
\hline GPX & $\mathrm{p}<0,05$ & $\mathrm{p}<0,01$ & $\mathrm{p}>0,05$ & $\mathrm{p}=0,0016$ \\
\hline GR & $\mathrm{NS}$ & $\mathrm{NS}$ & $\mathrm{NS}$ & $\mathrm{NS}$ \\
\hline TBARS & $\mathrm{NS}$ & $\mathrm{NS}$ & $\mathrm{NS}$ & $\mathrm{NS}$ \\
\hline TAS & $\mathrm{p}<0,001$ & $\mathrm{p}<0,001$ & $\mathrm{p}>0,05$ & $\mathrm{p}<0,0001$ \\
\hline
\end{tabular}

NS - não significativo

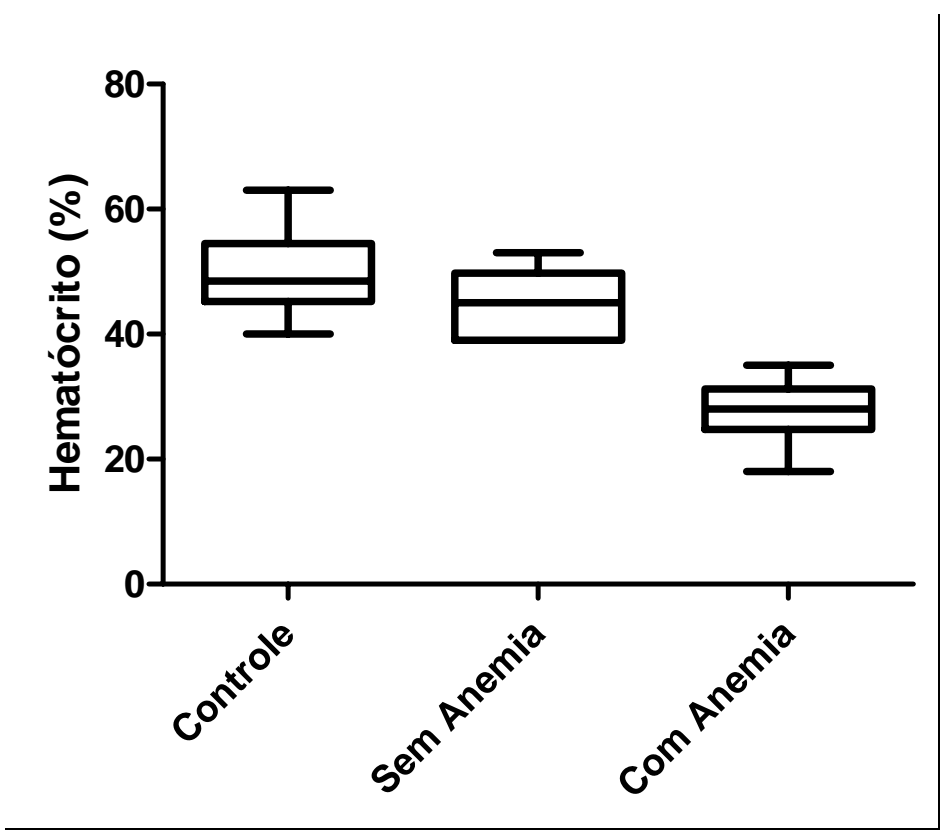

Gráfico 1 - Representação dos valores de mediana (linha central) e mínimo e máximo (delimitação do quadrilátero) do hematócrito (\%) dos cães do grupo controle, cães com linfoma multicêntrico e sem anemia e cães com linfoma multicêntrico e com anemia - São Paulo - 2010 


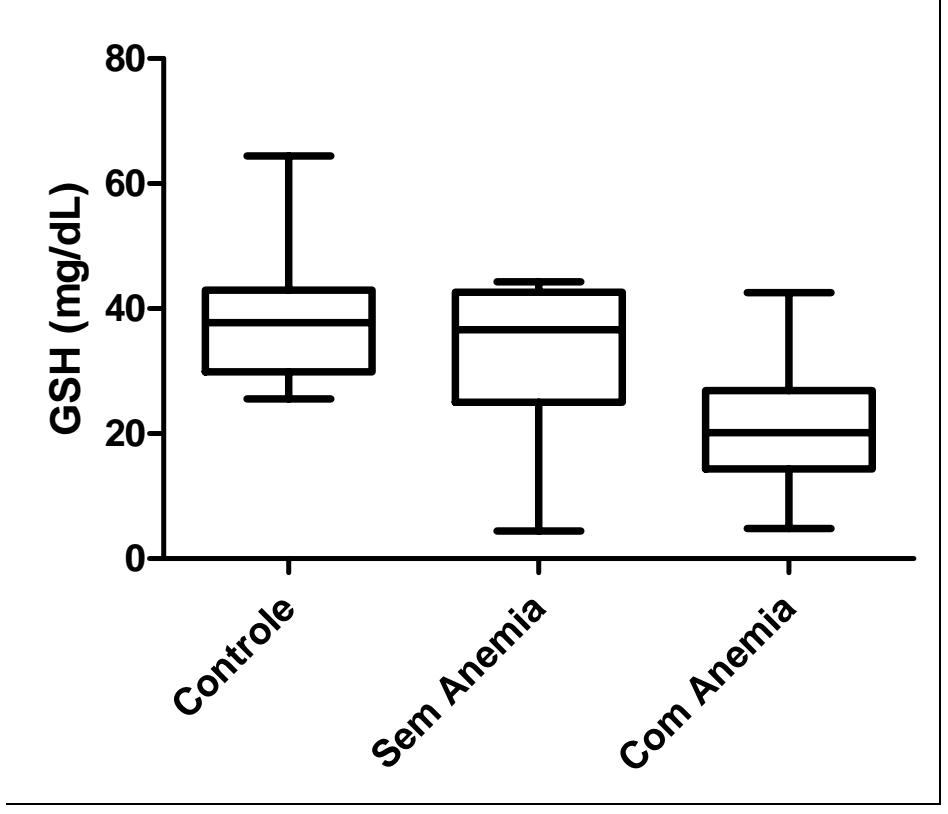

Gráfico 2 - Representação dos valores de mediana (linha central) e mínimo e máximo (delimitação do quadrilátero) da glutationa reduzida eritrocitária $(\mathrm{mg} / \mathrm{dL})$ dos cães do grupo controle, cães com linfoma multicêntrico e sem anemia e cães com linfoma multicêntrico e com anemia - São Paulo - 2010

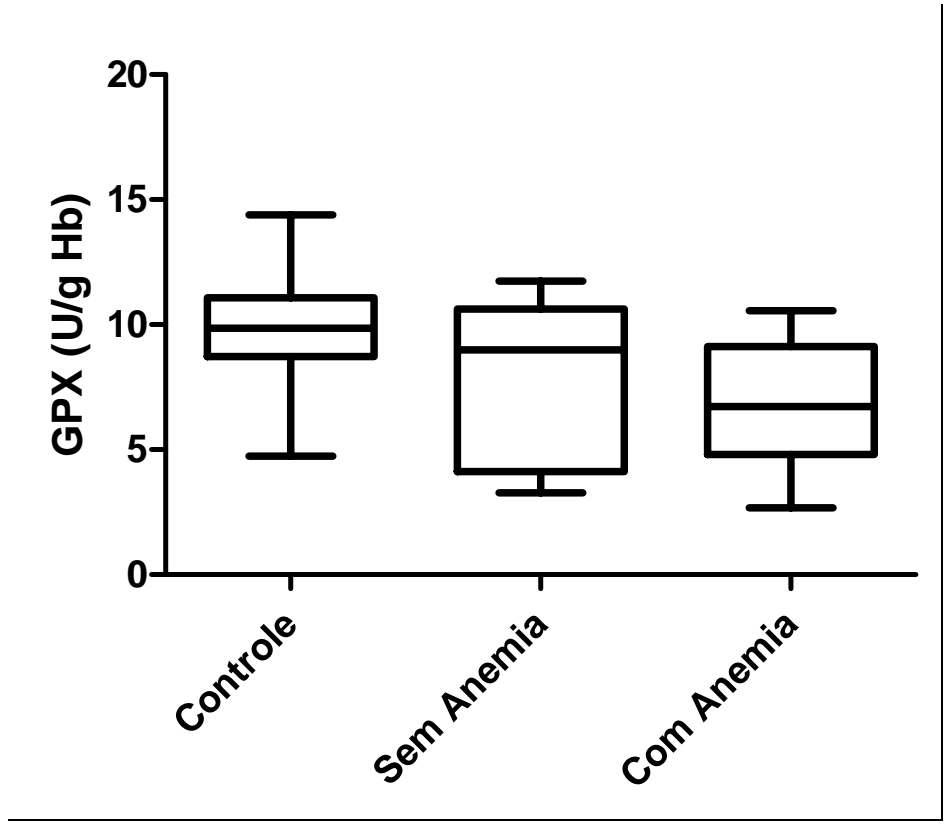

Gráfico 3 - Representação dos valores de mediana (linha central) e mínimo e máximo (delimitação do quadrilátero) da glutationa peroxidase eritrocitária $(\mathrm{U} / \mathrm{g} \mathrm{Hb})$ dos cães do grupo controle, cães com linfoma multicêntrico e sem anemia e cães com linfoma multicêntrico e com anemia - São Paulo - 2010 


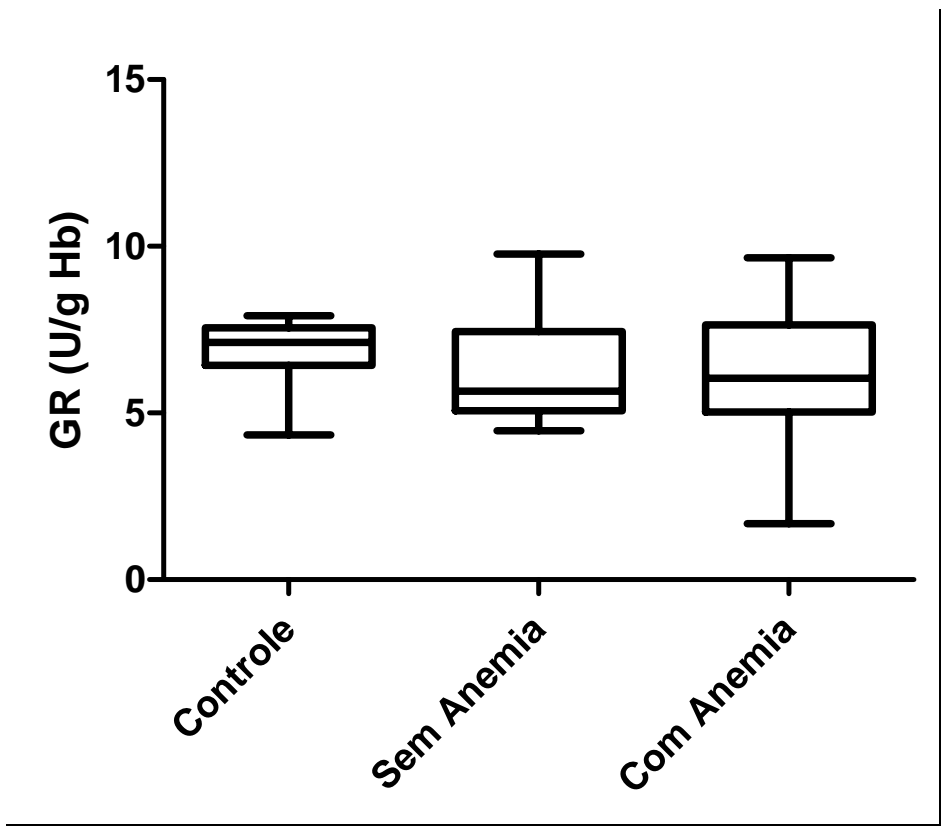

Gráfico 4 - Representação dos valores de mediana (linha central) e mínimo e máximo (delimitação do quadrilátero) da glutationa redutase eritrocitária $(\mathrm{U} / \mathrm{g} \mathrm{Hb})$ dos cães do grupo controle, cães com linfoma multicêntrico e sem anemia e cães com linfoma multicêntrico e com anemia - São Paulo - 2010

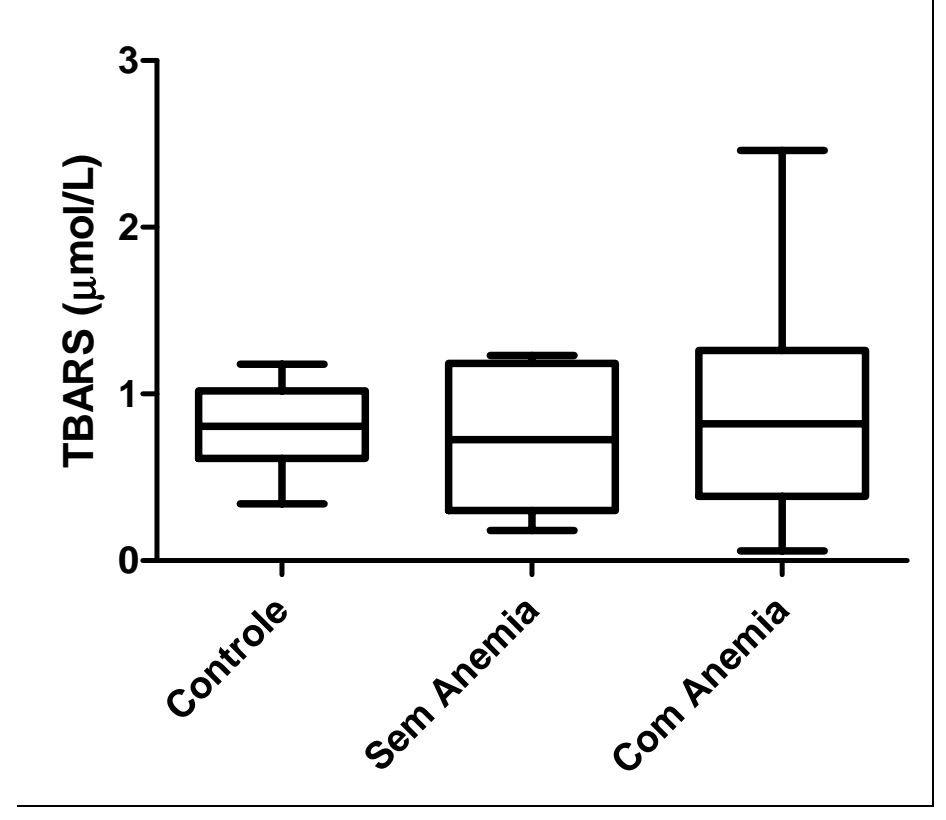

Gráfico 5 - Representação dos valores de mediana (linha central) e mínimo e máximo (delimitação do quadrilátero) da concentração plasmática da substância reativa ao ácido tiobarbitúrico (TBARS) $(\mu \mathrm{mol} / \mathrm{L})$ dos cães do grupo controle, cães com linfoma multicêntrico e sem anemia e cães com linfoma multicêntrico e com anemia - São Paulo - 2010 


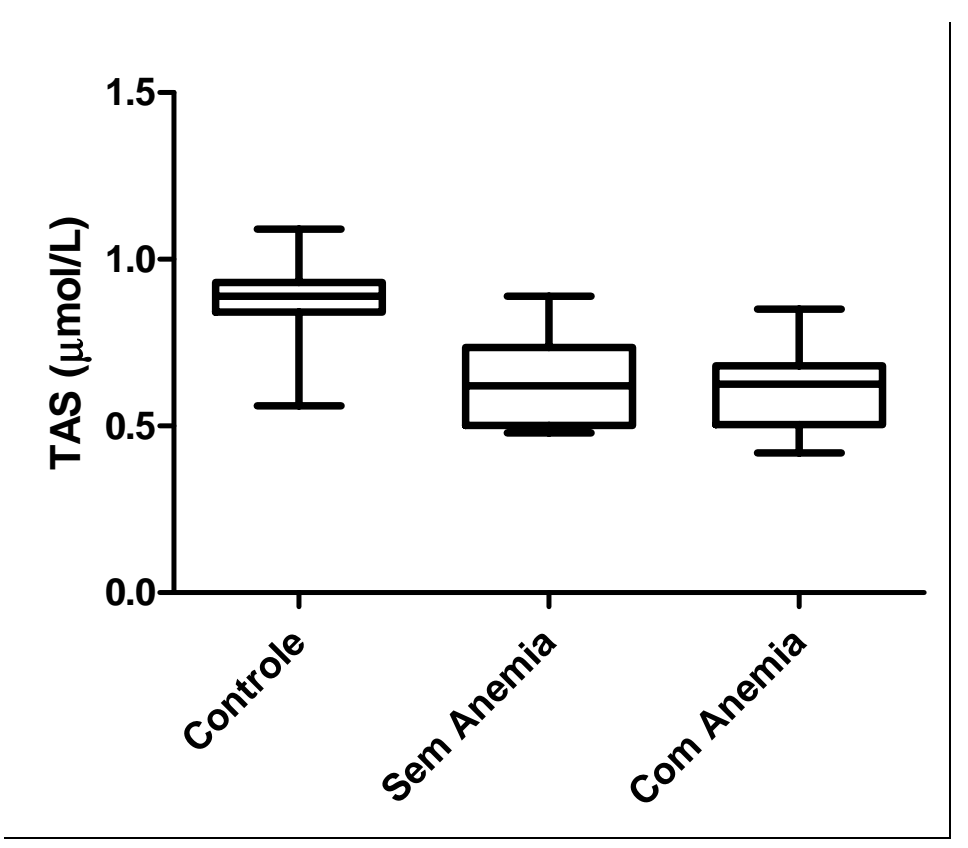

Gráfico 6 - Representação dos valores de mediana (linha central) e mínimo e máximo (delimitação do quadrilátero) do estado antioxidante total (TAS) $(\mu \mathrm{mol} / \mathrm{L})$ dos cães do grupo controle, cães com linfoma multicêntrico e sem anemia e cães com linfoma multicêntrico e com anemia - São Paulo - 2010

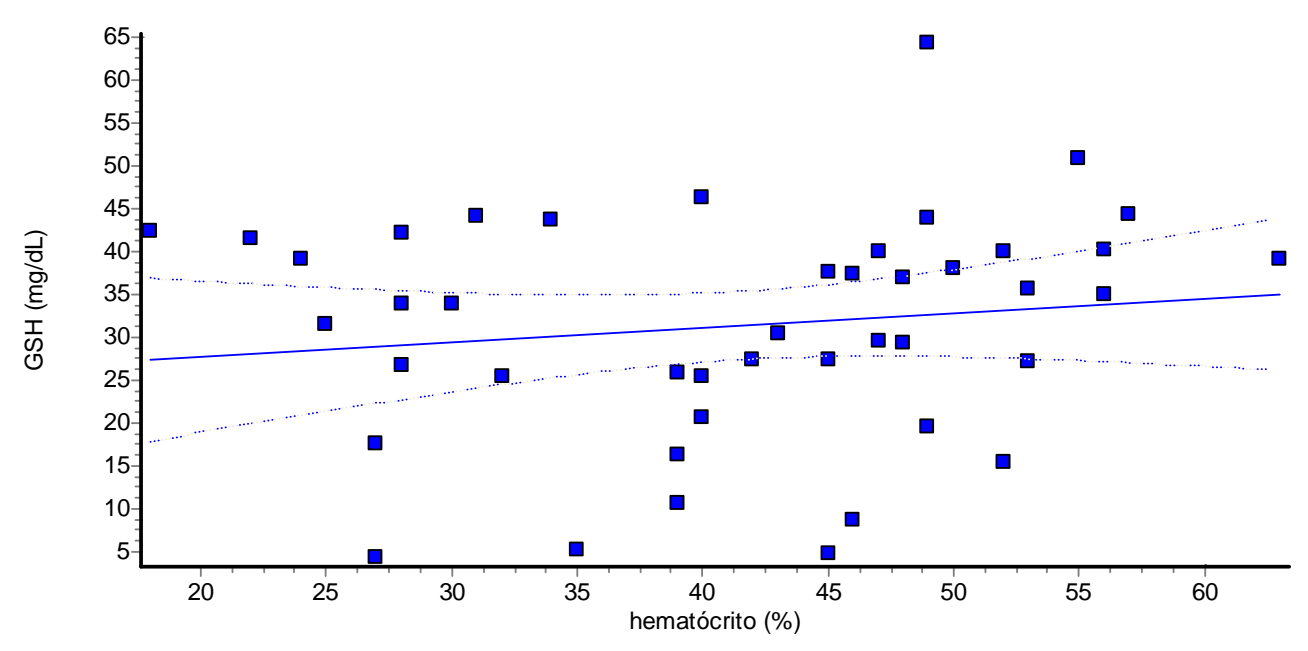

Gráfico 7 - Curva de regressão entre os valores de hematócrito e os valores intraeritrocitários de glutationa reduzida (GSH) dos cães sadios e com linfoma multicêntrico com e sem anemia - São Paulo - 2010 


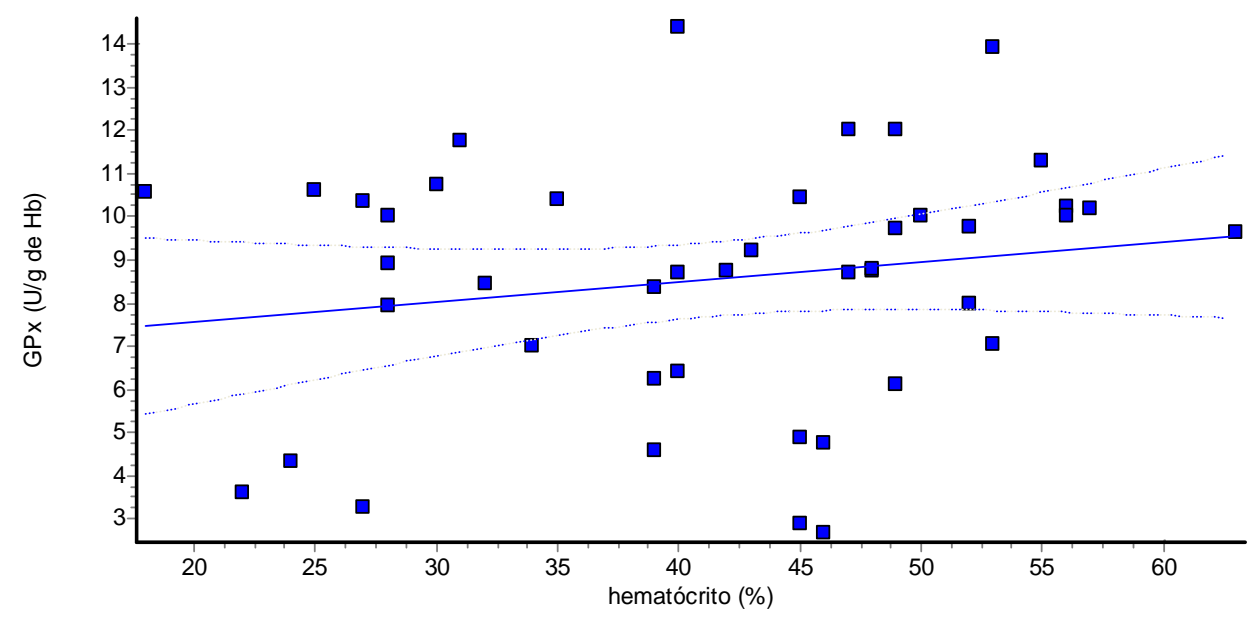

Gráfico 8 - Curva de regressão entre os valores de hematócrito e os valores intraeritrocitários de glutationa peroxidase (GPX) dos cães sadios e com linfoma multicêntrico com e sem anemia - São Paulo - 2010

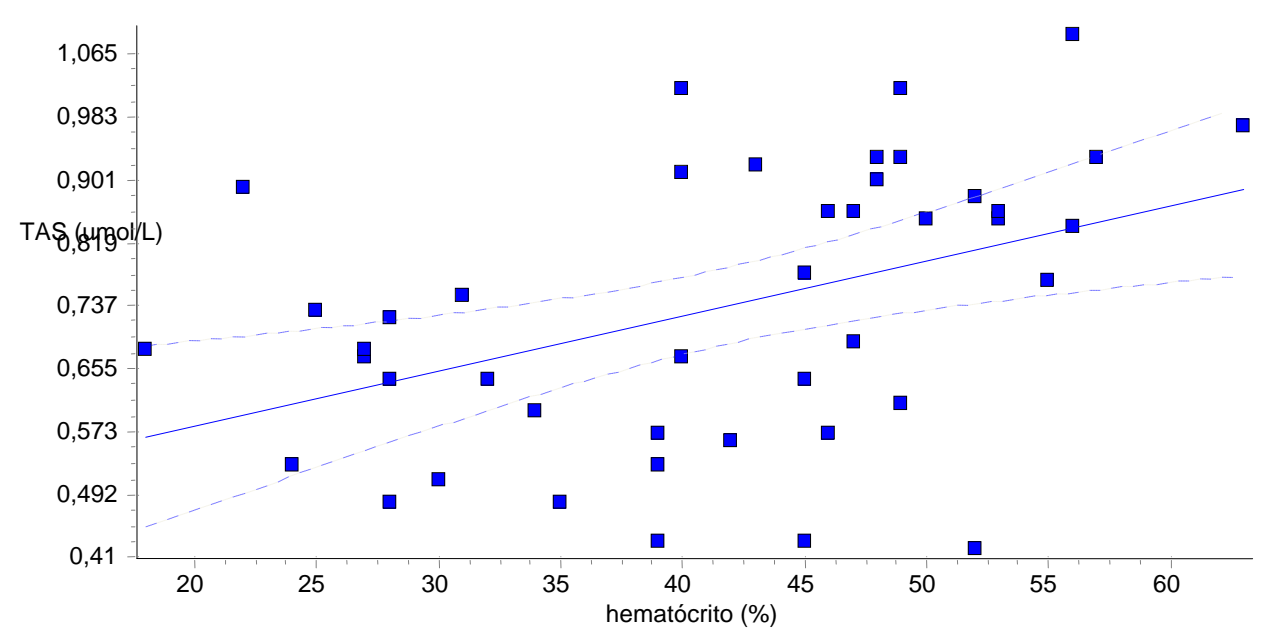

Gráfico 9 - Curva de regressão entre os valores de hematócrito e os valores do estado antioxidante total (TAS) dos cães sadios e com linfoma multicêntrico com e sem anemia - São Paulo - 2010 


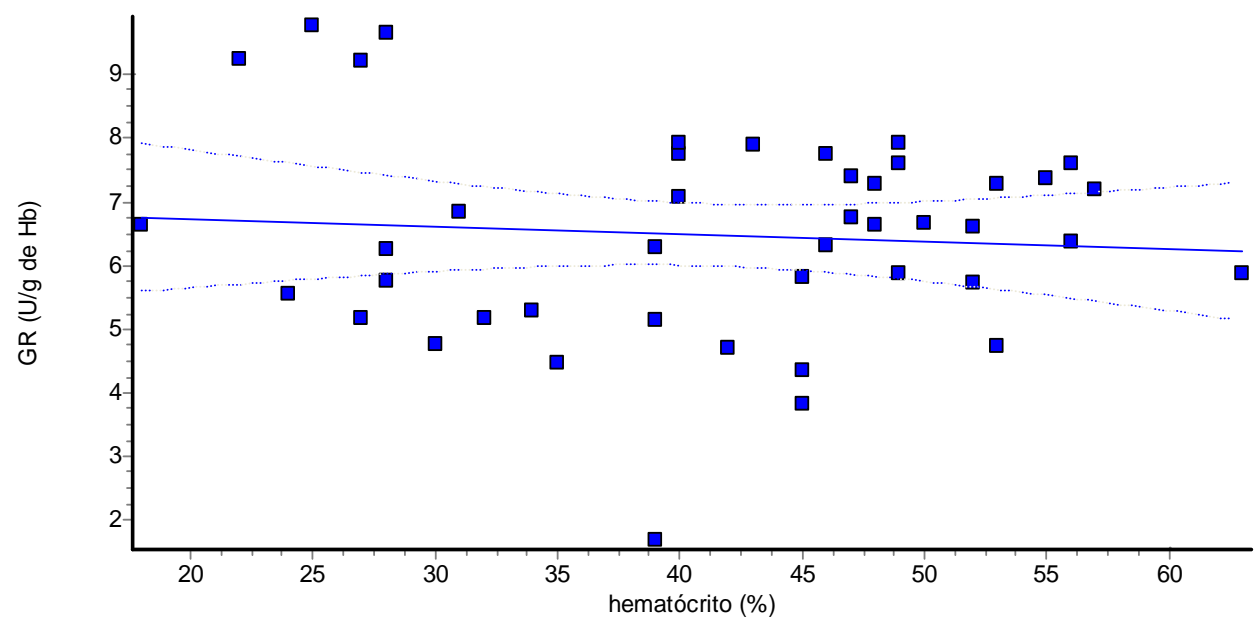

Gráfico 10 - Curva de regressão entre os valores de hematócrito e os valores intraeritrocitários de glutationa redutase (GR) dos cães sadios e com linfoma multicêntrico com e sem anemia - São Paulo - 2010

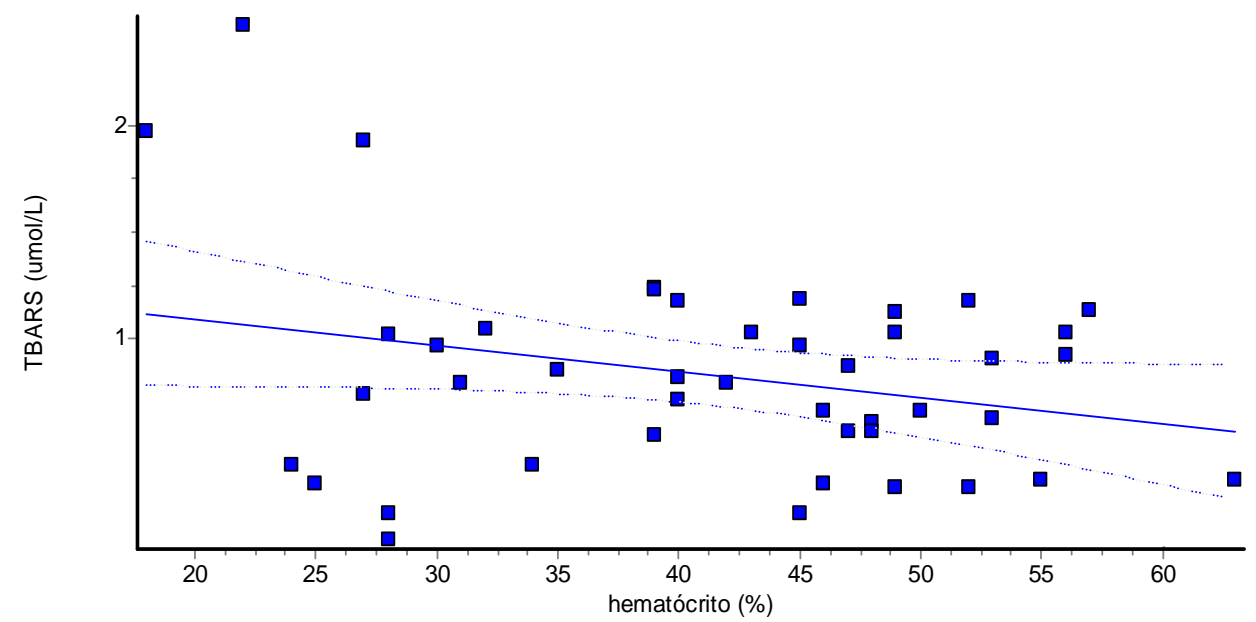

Gráfico 11 - Curva de regressão entre os valores de hematócrito e os valores da concentração plasmática das substâncias reativas ao ácido tiobarbitúrico (TBARS) dos cães sadios e com linfoma multicêntrico com e sem anemia São Paulo - 2010 


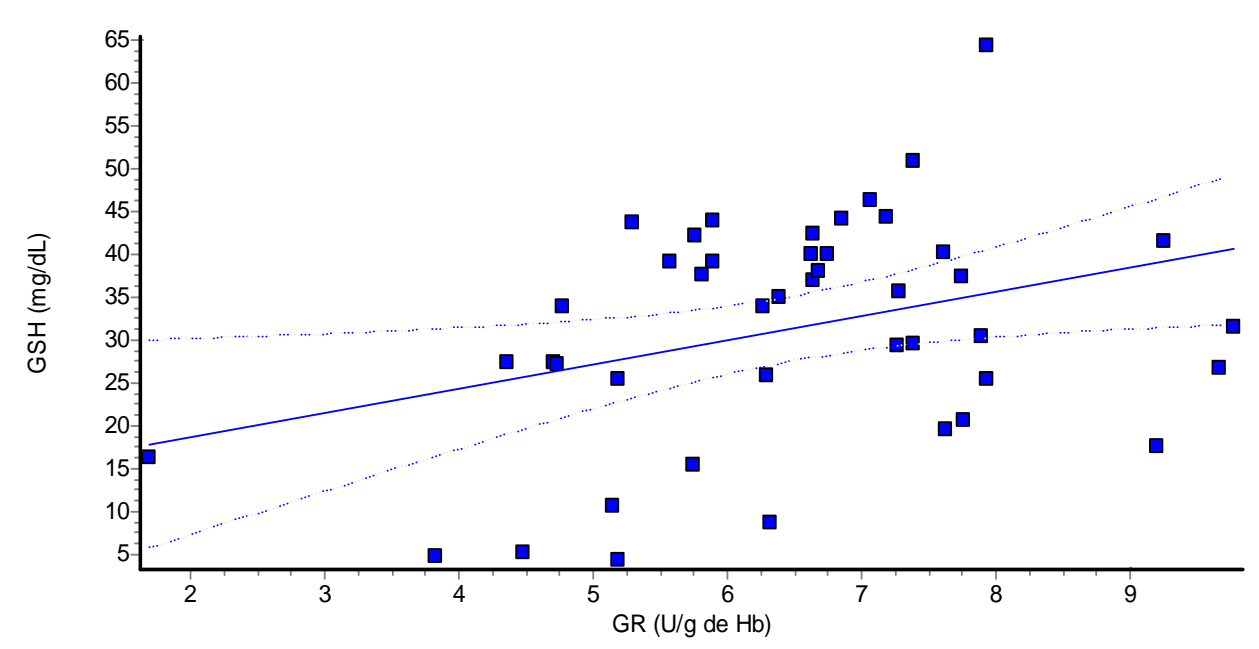

Gráfico 12 - Curva de regressão entre os valores intraeritrocitários de glutationa reduzida (GSH) e valores intraeritrocitários de glutationa redutase (GR) dos cães sadios e com linfoma multicêntrico com e sem anemia - São Paulo - 2010

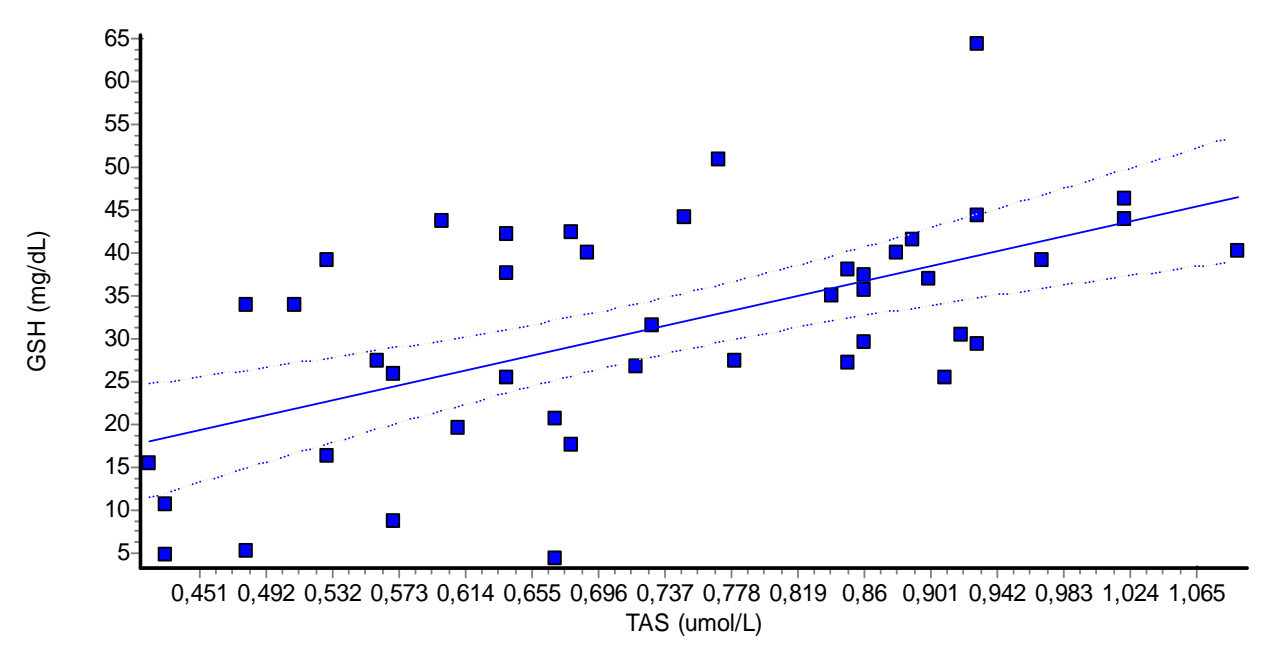

Gráfico 13 - Curva de regressão entre os valores intraeritrocitários de glutationa reduzida (GSH) e valores do estado antioxidante total (TAS) dos cães sadios e com linfoma multicêntrico com e sem anemia - São Paulo - 2010 


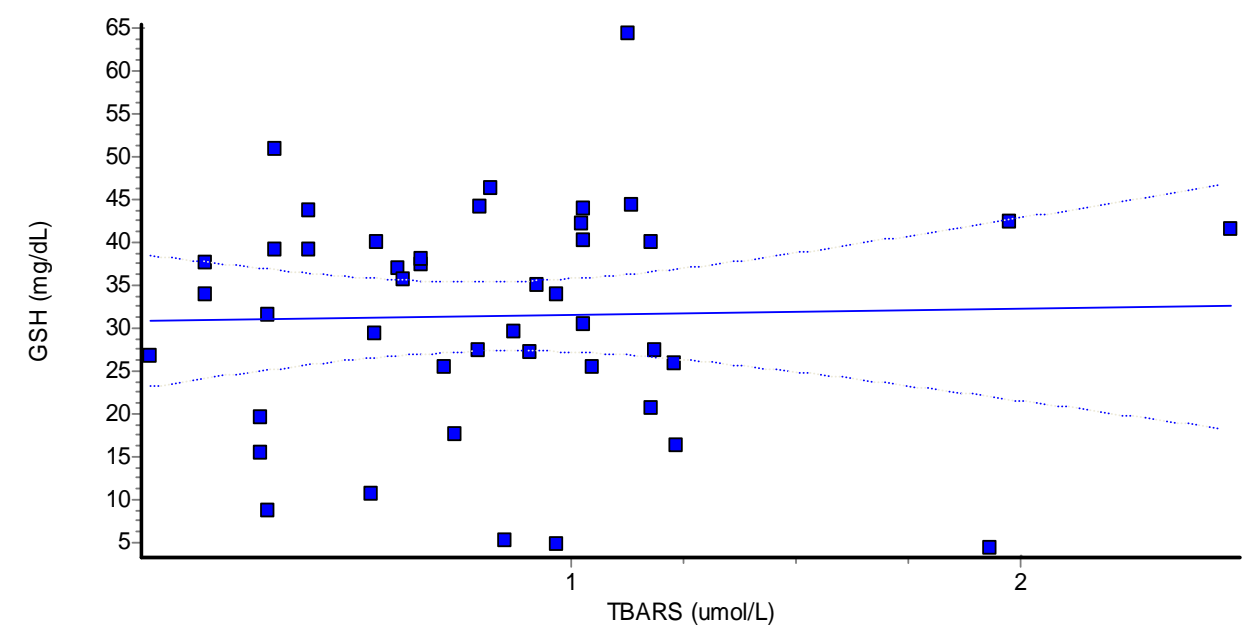

Gráfico 14 - Curva de regressão entre os valores intraeritrocitários de glutationa reduzida (GSH) e valores da concentração plasmática das substâncias reativas ao ácido tiobarbitúrico (TBARS) dos cães sadios e com linfoma multicêntrico com e sem anemia - São Paulo - 2010 


\section{DISCUSSÃO}

O estresse oxidativo representa um desequilíbrio dos mecanismos de defesa antioxidantes em favor das substâncias oxidantes, o que pode levar a dano celular. Neste estudo, observou-se que o estresse oxidativo esteve presente e pôde ser verificado pela diferença significativa na capacidade antioxidante inferida pelos níveis de antioxidantes totais (TAS), que se apresentaram diminuídos nos animais com linfoma, com e sem anemia, quando comparados aos controles, sendo esses níveis provavelmente insuficientes para conter a oxidação, gerando o estresse oxidativo, já que o mesmo pode ocorrer tanto por aumento da oxidação dos componentes celulares como pela deficiência dos mecanismos antioxidantes. É fato que várias outras afecções podem gerar o estresse oxidativo e, para evitar essa interferência, foram excluídos do estudo os animais que apresentavam alterações nos exames físico e laboratoriais que sabidamente pudessem interferir com as análises aqui realizadas. Assim, pelos resultados do estudo, a diminuição do chamado estado antioxidante total estaria relacionada à ocorrência do linfoma em si, e foi verificada independente do fato de o animal apresentar ou não anemia. Entretanto, na análise de correlação entre o hematócrito e o estado antioxidante total foi possível observar que a diminuição dos antioxidantes foi mais acentuada nos casos de anemia.

Embora existam muitas dificuldades na comparação de resultados de estudos que avaliam o estresse oxidativo, dada a ausência de padronização de técnicas, esses resultados concordam com aqueles de Vajdovich et al. (2005), que trabalharam com plasma e tecido linfóide de animais com linfoma e verificaram que esses animais não apresentaram aumento da capacidade de defesa antioxidante com relação aos animais sadios e, segundo os autores, isso seria explicado porque numa fase mais adiantada da doença as células têm sua capacidade antioxidante comprometida. Esse processo poderia ocorrer nos animais do presente estudo, uma vez que, em sua maioria, apresentavam-se em estágio IV ou $\mathrm{V}$ da doença.

Segundo o mesmo autor, as células linfóides neoplásicas pouco diferenciadas estão sob forte estresse oxidativo "in vivo", o que não somente afeta o tecido tumoral, mas também se reflete no plasma e nas hemácias alterando o metabolismo de glutationa e 
superóxido dismutase, enzima importante na manutenção do estado antioxidante, contribuindo para a diminuição das defesas. Nossos resultados também concordam parcialmente com os de Winter et al. (2009), para os quais houve diminuição de dois parâmetros utilizados na avaliação do estado antioxidante ( $\alpha$ e $\gamma$ tocoferol ) e elevação na glutationa peroxidase e capacidade de absorbância do oxigênio.

De modo geral, outros estudos com pacientes humanos e diferentes tipos de tumores, detectaram um baixo nível de antioxidantes nos pacientes doentes com relação aos controles, antes do início do tratamento antineoplásico (AGUS; VERA; GOLDE, 1999; DÜRKEN et al., 2000). A partir desses resultados, alguns pesquisadores sugeriram que o baixo estado antioxidante poderia ser associado com alta atividade das células neoplásicas, e como consequência, a uma piora do quadro clínico do doente. Essas observações reforçaram a idéia, ainda não completamente comprovada, de que a suplementação antioxidante poderia trazer benefícios aos pacientes oncológicos (LADAS et al., 2004).

Associado a isso, outros pesquisadores, como Shacter et al. (2000), analisaram se o uso de oxidantes, que simulariam um estado de estresse oxidativo, interferiria com a ação de agentes antineoplásicos "in vitro", em linhagens celulares de linfoma de Burkitt. Os pesquisadores concluíram que o peróxido interfere com a ação dos antineoplásicos sobre as células tumorais, diminuindo sua eficácia, o que poderia levar a um aumento do fenômeno de resistência a múltiplas drogas. Dessa forma, mecanismos antioxidantes eficientes seriam importantes não apenas para conter a evolução da neoplasia, mas também para aumentar a eficiência da terapia antineoplásica (SHACTER et al., 2000).

Apesar de não haver diferença estatisticamente significativa, os cães do grupo com linfoma multicêntrico e anemia apresentaram concentrações mais altas de substâncias reativas ao ácido tiobarbitúrico (pela reação com o malondialdeído) quando comparados com o grupo controle e também com o grupo de cães com linfoma multicêntrico e sem anemia. Resultado similar havia sido observado no Brasil por Lucas et al. (2008) e Winter et al. (2009) que observaram diferença estatisticamente significativa entre animais com linfoma e controles sadios, demonstrando o aumento na peroxidação lipídica e alteração na homeostasia redox, entretanto, os autores consideraram apenas a ocorrência do linfoma e não compararam animais com e sem anemia. 
Com relação aos seres humanos, Morabito et al. (2004) e Kaya et al. (2005) observaram níveis significativamente altos de malondialdeído em pacientes humanos com linfoma de Hodgkin comparados aos controles, confirmando a alteração na homeostase de oxirredução pelo aumento na concentração de radicais livres.

$\mathrm{Na}$ correlação entre o hematócrito e substâncias reativas ao ácido tiobarbitúrico o aumento da concentração dessas substâncias não acompanhou a diminuição do hematócrito e é possível que realmente não exista a correlação ou a não significância do resultado, neste estudo, esteja associada ao número de animais com anemia avaliados.

Abou-Seif, Rabia e Nasr (2000) demonstraram, em pacientes humanos com linfoma, que o aumento da peroxidação lipídica resulta em alterações na propriedade da membrana das hemácias levando à morte celular em conjunto com o aumento da fragilidade osmótica e mudanças nas atividades das enzimas antioxidantes, portanto o estresse oxidativo produzido pelo linfoma seria a causa das complicações hematológicas. Crianças com leucemia linfoblástica aguda apresentam aumento de substâncias reativas ao ácido tiobarbitúrico indicando aumento do estado oxidativo, sendo esta, segundo os autores, uma das causas da anemia nesses pacientes (GHOSH et al.,2005).

Em cães e gatos com insuficiência renal crônica e anemia, acredita-se que o aumento da concentração de substâncias reativas ao ácido tiobarbitúrico tenha relação com a intensidade da anemia, assim como com a evolução da doença (LUSTOZA, 2004; SANTOS, 2005).

A baixa concentração de hemoglobina pode contribuir com o dano oxidativo da membrana da hemácia por tornar os componentes da membrana mais suscetíveis aos oxidantes (malondialdeído). A hemoglobina atua como um "tampão" e protege outros constituintes das hemácias de oxidantes que ocorrem naturalmente, tornando-se oxidada (metahemoglobina) nesse processo. $\mathrm{O}$ acúmulo da metahemoglobina no sangue pode aumentar a hipóxia tecidual em pacientes anêmicos devido à sua baixa afinidade pelo oxigênio, associado ao dano à membrana da hemácia, que altera sua função e estabilidade. Este mecanismo pode exercer papel importante no tempo de vida do eritrócito e contribuir para a anemia (PAVRI et al., 1983). 
Estudos em humanos e cães com linfoma também observaram a ocorrência de diminuição das concentrações de glutationa reduzida (ARMSTRONG et al., 2002; VAJDOVICH et al., 2005). A glutationa participa de vários processos biológicos, incluindo síntese de proteína e DNA, transporte de aminoácidos, atividade de enzimas e proteção celular contra radicais livres e carcinógenos. O fígado, rins, mucosa intestinal e eritrócitos contêm as maiores quantidades de glutationa, provavelmente devido à sua alta exposição aos radicais livres e pela sua suscetibilidade para auto-oxidação após lesão pelo radical livre. A presença da glutationa nas hemácias assim como das enzimas que controlam seu metabolismo, é capaz de interromper processos que levam à fragilidade da membrana, hemólise, aumento de remoção pelo sistema reticuloendotelial e anemia (FETTMAN, 1991).

Durante o processo de oxidação, ocorre inativação do mesmo pela produção de glutationa oxidada a partir da glutationa reduzida. Quando esse mecanismo de defesa encontra-se íntegro, existe recuperação da glutationa reduzida. Em situações que ocorrem excesso de agentes oxidantes e/ou deficiência de mecanismos de proteção, ocorre um desequilíbrio entre o consumo de glutationa reduzida e a produção de glutationa oxidada levando ao estresse oxidativo (FERREIRA; MATSUBARA, 1997).

No presente estudo, foi possível observar que a concentração eritrocitária da glutationa reduzida foi significativamente menor no grupo de cães com linfoma multicêntrico e com anemia comparados ao grupo controle (sadios), assim como quando comparados os grupos de cães doentes (com linfoma multicêntrico com e sem anemia) e o grupo controle (sadios), demonstrando assim maior utilização da substância antioxidante pela célula. Nesse caso, a anemia parece influenciar as concentrações de glutationa reduzida quando comparados os cães do grupo com linfoma multicêntrico e sem anemia e cães do grupo controle. Esses dados demonstram, portanto que a anemia pode ser um fator determinante na maior utilização da glutationa reduzida na tentativa de restabelecer a homeostase. Já na análise de correlação entre o hematócrito e a concentração eritrocitária de glutationa reduzida, a intensidade da anemia não interferiu com a sua concentração, ou seja, a anemia por si já é um fator para aumentar o estresse oxidativo eritrocitário.

Foi possível identificar na análise de correlação entre glutationa reduzida e estado antioxidante total que as substâncias antioxidantes estavam significativamente mais 
baixas nos pacientes com linfoma em comparação com os cães do grupo controle, ocasionando o estresse oxidativo.

De acordo com Hopkins e Tudhope (1973), a glutationa peroxidase, que reduz o $\mathrm{H}_{2} \mathrm{O}_{2}$ pela oxidação da glutationa reduzida para glutationa oxidada (BURAK ÇIMEN, 2008; HOPKINS; TUDHOPE, 1973), é de fundamental importância na proteção das hemácias contra o dano oxidativo, entretanto, Arruda et al. (1996) e Ghaffari (2008)afirmam que sua deficiência parece não afetá-las, já que a enzima catalase também é igualmente ativa na detoxificação do peróxido de hidrogênio nos eritrócitos.

Deficiências de glutationa peroxidase assim como da superóxido dismutase são importantes. A integridade das hemácias necessita de um sistema antioxidante intacto para prevenir uma hemólise oxidativa e drogas oxidantes são um perigo em potencial para pacientes com deficiência dessa proteção enzimática. Pacientes com linfoma geralmente são tratados com múltiplas drogas, algumas delas com potencial oxidante para as hemácias. O risco de formação de metahemoglobina e corpúsculos de Heinz, e anemia hemolítica subsequente é um grande agravante para pacientes com deficiência dessas enzimas (BEWICK; COUTLE; TUDHOPE, 1987).

Avaliando a atividade das enzimas antioxidantes e peroxidação lipídica em pacientes humanos com mieloma múltiplo, Zima et al. (1996), observaram que esses pacientes tinham concentrações eritrocitárias de glutationa peroxidase mais baixas enquanto as concentrações de malondialdeído total estavam mais altas, demonstrando assim que o estresse oxidativo potencializava a doença provavelmente como consequência da diminuição das defesas antioxidantes.

A glutationa peroxidase apresentou diminuição significativa da sua atividade nos grupos de cães com linfoma multicêntrico e com anemia e no grupo de cães doentes (com linfoma multicêntrico com e sem anemia). Quando comparados os grupos de cães com linfoma multicêntrico e sem anemia e cães com linfoma multicêntrico e com anemia, não houve diferença significativa, assim como na comparação dos cães do grupo controle com os cães com linfoma multicêntrico e sem anemia. Apesar de não significativa, a média da concentração de glutationa peroxidase nos cães com linfoma multicêntrico e com anemia $(6,94 \mathrm{U} / \mathrm{g} \mathrm{Hb})$ encontrava-se mais baixa quando comparadas com os cães com linfoma multicêntrico e sem anemia $(7,96 \mathrm{U} / \mathrm{g} \mathrm{Hb})$, mas não se correlacionou ao hematócrito. Com base nesses dados, pôde-se inferir que a diminuição da glutationa 
peroxidase está relacionada com o aumento do estresse oxidativo que o linfoma promove (VAJDOVICH et al., 2005), porém não com a intensidade da anemia, provavelmente porque a detoxificação do peróxido de hidrogênio não é dependente apenas da ação dessa enzima, mas também pela atividade da catalase (ARRUDA et al., 1996), não avaliada no presente estudo.

Assim como no presente estudo; Bewick, Coutle e Tudhope (1987) observaram que a glutationa peroxidase nas hemácias encontrava-se diminuída em pacientes humanos com linfoma, diminuindo assim a proteção contra a oxidação. Estes resultados contrastam com estudo anterior de Gonzales et al. (1984), que não observaram alterações nos valores de glutationa peroxidase e com o estudo de Winter et al. (2009) que observaram aumento nas concentrações antes e após o tratamento. Esse conflito de resultados acredita-se que possa ser atribuído aos diferentes estágios clínicos (classificados segundo a Organização Mundial da Saúde) da apresentação dos pacientes no momento do estudo (animais em estágio mais avançado da doença) ou pelos diferentes imunofenótipos (WINTER et al., 2009).

Não foram observadas diferenças significativas entre os grupos com relação à enzima glutationa redutase. $\mathrm{Na}$ análise de correlação entre o hematócrito e glutationa redutase também não foram observados resultados significativos.

A glutationa redutase é a enzima responsável por catalisar a reação da glutationa oxidada para glutationa reduzida com utilização de NADPH, mantendo assim a concentração de glutationa reduzida, a substância antioxidante mais abundante nas células humanas (KAMERBEEK et al., 2007).

Lustoza (2004) também observou que cães com insuficiência renal crônica e anemia não apresentaram aumento da sua atividade. Atribui-se a essa condição provavelmente o excesso de perda de vitaminas do complexo B aliada ao estado de desnutrição dos pacientes. Entretanto, a administração de riboflavina não parece restaurar a atividade da glutationa redutase devido a mutações em genes que codificam a enzima (KAMERBEEK et al., 2007).

Na correlação entre a glutationa reduzida e substâncias reativas ao ácido tiobarbitúrico a análise mostrou-se não significativa, ou seja, o aumento da peroxidação lipídica não ocasionou uma resposta compensatória para aumentar a concentração de glutationa reduzida no intuito de restabelecer a homeostase. Esse fato pode ser explicado 
principalmente pela atividade inalterada da enzima glutationa redutase entre os grupos, o que impede que a glutationa oxidada seja regenerada para sua forma reduzida.

Correlação significativa entre glutationa reduzida e a enzima glutationa redutase foi observada, entretanto não houve aumento da concentração de glutationa reduzida nos pacientes doentes, provavelmente pela deficiência que já ocorria pelo aumento do estresse oxidativo e atividade inalterada da enzima glutationa redutase.

Assim como o linfoma, outras neoplasias foram descritas por aumentar o estresse oxidativo (CHING et al., 2002; SZCZUBIAL et al., 2004; VALKO et al., 2004; KENNEDY et al., 2005; KUMARAGURUPARAN et al., 2005; LI et al., 2005; ELANGO; SAMUEL; CHINNAKKANNU, 2006; GÖNENÇ et al., 2006; VALKO et al., 2006). Alterações nas hemácias devido ao desequilíbrio entre substâncias oxidantes e antioxidantes também são descritas em seres humanos com câncer (PAVRI et al., 1983; KUMEROVA et al., 1998; ABOU-SEIF; RABIA; NASR, 2000; RIFKIND et al., 2003; GHOSH et al., 2005; MACCIÒ et al., 2005; GHOTI et al., 2007; NOVOTNA et al., 2009). Os resultados deste estudo indicam que a defesa antioxidante plasmática e intraeritrocitária, assim como o estado oxidante estão alterados nos cães com linfoma e principalmente naqueles com anemia. Estudos posteriores com acompanhamento de tratamento e imunofenotipagem serão necessários para esclarecer as modificações decorrentes da quimioterapia antineoplásica nesses parâmetros oxidativos, haja vista o pior prognóstico dos casos de linfoma que evoluem com anemia. 


\section{CONCLUSÕES}

Diante dos resultados obtidos com a metodologia utilizada neste estudo, foi possível concluir que:

- Cães com linfoma multicêntrico com e sem anemia encontram-se sob maior estresse oxidativo, o que pode ser comprovado pela diminuição do estado antioxidante total, das concentrações intraeritrocitárias de glutationa reduzida e da atividade da enzima glutationa peroxidase;

- Apesar dos valores não significativos, as concentrações plasmáticas de substâncias reativas ao ácido tiobarbitúrico encontraram-se ligeiramente mais altos nos cães com linfoma multicêntrico, principalmente no grupo com anemia, sugerindo assim, maior peroxidação lipídica;

- A glutationa reduzida, importante antioxidante, encontra-se em concentrações mais baixas em cães com linfoma multicêntrico, sendo as concentrações ainda mais reduzidas naqueles com anemia;

- A diminuição do estado antioxidante total correlaciona-se diretamente com o hematócrito, enquanto a diminuição da glutationa reduzida relaciona-se com a anemia independente da intensidade da redução do hematócrito. 


\section{REFERÊNCIAS}

ABBO, A. H.; LUCROY, M. D. Assessment of anemia as an independent predictor of response to chemotherapy and survival in dogs with lymphoma: 96 cases (1993-2006). Journal of the Veterinary Medical Association, v. 231, n. 12, p. 1836-1842, 2007.

ABOU-SEIF, M. A. M.; RABIA, A.; NASR, M. Antioxidant status, erythrocyte membrane lipid peroxidation and osmotic fragility in malignant lymphoma patients. Clinical Chemistry and Laboratory Medicine, v. 38, n. 8, p. 737-742, 2000.

AGUS, D. B.; VERA, J. C.; GOLDE, D. W. Stromal cell oxidation: a mechanism by wich tumors obtain vitamin C. Cancer Research, v. 59, p. 4555-4558, 1999.

ARMSTRONG, J. S.; STEINAUER, K. K.; HORNUNG, B.; IRISH, J. M.; LECANE, P.; BIRRELL, G. W.; PEEHL, D. M.; KNOX, S. J. Role of glutathione depletion and reactive oxygen species generation in apoptotic signaling in a human B lymphoma cell line. Cell Death and Differentiation, v. 9, n. 3, p. 252-263, 2002.

ARRUDA, V. R.; SALLES, T. S. I.; COSTA, F. F.; SAAD, S. T. O. Glutathione peroxidase, reduced glutathione, superoxide dismutase and catalase in red cells of patients with hairy cell leukemia. Neoplasma, v. 43, n. 2, p. 99-102, 1996.

BABU, C. K.; KHANNA, S. K.; DAS, M. Antioxidant status of erythrocytes and their response to oxidative challenge in humans with argemone oil poisoning. Toxicology and Applied Pharmacology, v. 230, p. 304-311, 2008.

BEUTLER, E.; DURON, O.; KELLY, B. M. Improved method for the determination of blood glutathione. Journal of Laboratory and Clinical Medicine, v. 61, n. 5, p. 882-888, 1963.

BEWICK, M.; COUTIE, W.; TUDHOPE, G. R. Superoxide dismutase, glutathione peroxidase and catalase in the red cells of patients with malignant lymphoma. British Journal of Haematology, v. 65, p. 347-350, 1987. 
BIRGEGARD, G.; GASCÓN, P.; LUDWIG, H. Evaluation of anaemia in patients with multiple myeloma and lymphoma: findings of the European cancer anaemia survey.

European Journal of Haematology, v. 77, p. 378-386, 2006.

BISHOP, L.; FAITHFULL, S.; ALLAN, H. An exploration of the influences on clinical decision making and the culture of blood transfusion practice in cancer-related anaemia using an ethnographic methodology. Support Care Cancer, 2010.

BUICO, A.; CASSINO, C.; RAVERA, M.; BETTA, P. G.; OSELLA, D. Oxidative stress and total antioxidant capacity in human plasma. Redox Report, v. 14, n. 3, p. 125-131, 2009.

BURAK ÇIMEN, M. Y. Free radical metabolism in human erythrocytes. Clinica Chimica Acta, v. 390, p. 1-11, 2008.

CARO, J. J.; SALAS, M.; WARD, A.; GOSS, G. Anemia as an independent prognostic factor for survival in patients with cancer. Cancer, v. 91, p. 2214-2221, 2001.

CHING, S.; INGRAM, D.; HAHNEL, R.; BEILBY, J.; ROSSI, E. Serum levels of micronutrients, antioxidants and total antioxidant status predict risk of breast cancer in a case control study. Journal of Nutrition, v. 132, n. 2, p. 303-306, 2002.

COUTO, C. G. Moléstias dos linfonodos e baço. In: ETTINGER, S. J.; FELDMAN, E. C. Tratado de medicina interna veterinária. 3. ed. São Paulo: Manole, 1992. cap. 115. p. 2328-2348.

DALLALIO, G.; MEANS, R. T. Effects of oxidative stress on human erythroid colony formation: modulation by $\gamma$-interferon. Journal of Laboratory and Clinical Medicine, $\mathrm{v}$. 141, n. 6, p. 394-400, 2003.

DÜRKEN, M.; HERRNRING, C.; FINCKH, B.; NAGEL, S.; NIELSEN, P.; FISCHER, R.; BERGER, H. M.; MOISON, R. M. W.; PICHLMEIER, U.; KOHLSCHÜTTER, B.; ZANDER, A. R.; KOHLSCHÜTTER, A. Impaired plasma antioxidative defense and increased nontransferrin-bound iron during high-dose chemotherapy and radiochemotherapy preceding bone marrow transplantation. Free Radical Biology \& Medicine, v. 28, n. 6, p. 887-894, 2000. 
ELANGO, N.; SAMUEL, S.; CHINNAKKANNU, P. Enzymatic and non-enzymatic antioxidant status in stage (III) human oral squamous cell carcinoma and treated with radical radio therapy: influence of selenium supplementation. Clinica Chimica Acta, v. 373, p. 9298, 2006.

ESTERBAUER, H.; CHEESEMAN, K. H. Determination of aldehydic lipid peroxidation products: Malonaldehyde and 4-hydroxynomenal. Methods in Enzimology, v. 186, p. 407421, 1990.

FELDMAN, B. F. Nonregenerative anemia. In: ETTINGER, S. J.; FELDMAN, E. C. Textbook of veterinary internal medicine. 6. ed. Philadelphia: W. B. Saunders Company, 2005, cap. 271, p. 1908-1917.

FERREIRA, A. L. A.; MATSUBARA, L. S. Radicais livres: conceitos, doenças relacionadas, sistema de defesa e estresse oxidativo. Revista da Associação Médica Brasileira, v. 43, n. 1, p. 61-68, 1997.

FETTMAN, M. J. Comparative aspects of glutathione metabolism affecting individual susceptibility to oxidant injury. Compendium on Continuing Education, v. 13, n. 7, p. 1079-1091, 1991.

FIBACH, E.; RACHMILEWITZ, E. The role of oxidative stress in hemolytic anemia. Current Molecular Medicine, v. 8, p. 609-619, 2008.

FINORA, K. Common paraneoplastic syndromes. Clinical Techniques in Small Animal Practice, v. 18, n. 2, p. 123-126, 2003.

GHAFFARI, S. Oxidative stress in the regulation of normal and neoplastic hematopoiesis. Antioxidants \& Redox Signaling, v. 10, n. 11, p. 1923-1940, 2008.

GHOTI, H.; AMER, J.; WINDER, A.; RACHMILEWITZ, E.; FIBACH, E. Oxidative stress in red blood cells, platelets and polymorphonuclear leukocytes from patients with myelodysplastic syndrome. European Journal of Haematology, v. 79, p. 463-467, 2007. 
GHOSH, S.; BANDYOPADHYAY, S.; BHATTACHARYA, D. K.; MANDAL, C. Altered erythrocyte membrane characteristics during anemia in childhood acute lymphoblastic leukemia. Annals of Hematology, v. 84, p. 76-84, 2005.

GIUSTARINI, D.; DALLE-DONNE, I.; COLOMBO, R.; MILZANI, A.; ROSSI, R. Interference of plasmatic reduced glutathione and hemolysis on glutathione disulfide levels in human blood. Free Radical Research, v. 38, n. 10, p. 1101-1106, 2004.

GÖNENÇ, A.; ERTEN, D.; ASLAN, S.; AKINCI, M.; SIMSEK, B.; TORUN, M. Lipid peroxidation and antioxidant status in blood and tissue of malignant breast tumor and benign breast disease. Cell Biology International, v. 30, p. 376-380, 2006.

GONZALES, R.; AUCLAIR, C.; VOLSIN, E.; GAUTERO, H.; DHERMY, D.; BOIVIN, P. Superoxide dismutase, catalase, and glutathione peroxidase in red blood cells from patients with malignant diseases. Cancer Research, v. 44, p. 4137-4139, 1984.

GREENE, C. E. Linfadenopatia. In: LORENZ, M. D.; CORNELIUS, L. M. Diagnóstico Clínico em Pequenos Animais. 2. ed. Rio de Janeiro: Interlivros, 1996. cap. 20, p. 117-119.

GRUNE, T.; SOMMERBURG, O.; SIEMS, W. G. Oxidative stress in anemia. Clinical Nephrology, v. 53, suppl. 1, p. S18-S22, 2000.

HALLIWELL, B.; GUTTERIDGE, J. M. C. Free radicals in biology and medicine. 3. ed. New York: Oxford Science Publications, 1999. 936 p.

HARPER, P.; LITTLEWOOD, T. Anaemia of cancer: impact on patient fatigue and longterm outcome. Oncology, v. 69, p. 2-7, 2005. Supplement, 2.

HARVEY, C. E. Moléstia da faringe e tonsilas. In: BOJRAB, M. J. Mecanismos da moléstia na cirurgia dos pequenos animais. 2. ed. São Paulo: Manole, 1996. cap. 62, p. 432-434.

HOPKINS, J.; TUDHOPE, G. R. Glutathione peroxidase in human red cells in health and disease. British Journal of Haematology, n. 25, p. 563-575, 1973. 
JAIN, C. N. Essentials of veterinary hematology. Philadelphia: Lea \& Febiger, 1993. 417 p.

KAMERBEEK, N. M.; VAN ZWIETEN, R.; DE BOER, M.; MORREN, G.; VUIL, H.; BANNINK, N.; LINCKE, C.; DOLMAN, K. M.; BECKER, K.; SCHIRMER, R. H.; GROMER, S.; ROOS, D. Molecular basis of glutathione reductase deficiency in human blood cells. Blood, v. 109, n. 8, p. 3560-3566, 2007.

KANNAN, S. Free radical theory of autoimmunity. Theoretical Biology and Medical Modelling, v. 3, n. 22, p. 1-15, 2006.

KAYA, E.; KESKIN, L.; AYDOGDU, I.; KUKU, I.; BAYRAKTAR, N.; ERKUT, M. A. Oxidant / antioxidant parameters and their relationship with chemotherapy in Hodgkin's lymphoma. The Journal of International Medical Research, v. 33, n. 6, p. 687-692, 2005.

KENNEDY, D. D.; LADAS, E. J.; RHEINGOLD, S. R.; BLUMBERG, J.; KELLY, K. M. Antioxidant status decreases in children with acute lymphoblastic leukemia during the first six months of chemotherapy treatment. Pediatric Blood \& Cancer, v. 44, n. 4, p. 378-385, 2005.

KOBUNE, M.; KATO, J.; NIITSU, Y. Anemia in patients with cancer. Nippon Rinsho. Japanese Journal of Clinical Medicine, v. 66, n. 3, p. 524-529, 2008.

KUMARAGURUPARAN, R.; BALACHANDRAN, C.; MANOHAR, B. M.; NAGINI, S. Altered oxidant - antioxidant profile in canine mammary tumours. Veterinary Research Communications, v. 29, p. 287-296, 2005.

KUMEROVA, A.; LECE, A.; SKESTERS, A.; SILOVA, A.; PETUHOVS, V. Anaemia and antioxidant defence of the red blood cells. Materia Medica Polona, v. 30, p. 12-15, 1998.

LADAS, E. J.; JACOBSON, J. S.; KENNEDY, D. D.; TEEL, K.; FLEISCHAUER, A.; KELLY, K. M. Antioxidants and cancer therapy: a systematic review. Journal of Clinical Oncology, v. 22, n. 3, p. 517-528, 2004.

LI, H.; KANTOFF, P. W.; GIOVANNUCCI, E.; LEITZMANN, M. F.; GAZIANO, J. M.; STAMPFER, M. J.; MA, J. Manganese superoxide dismutase polymorphism, prediagnostic antioxidant status, and risk of clinical significant prostate cancer. Cancer Research, v. 65, n. 6, p. 2498-2504, 2005. 
LUCAS, S. R. R.; GIMENO, M. G.; MORI, C. S.; WIRTHL, V. A. B. F. Evaluation of oxidant/antioxidant status in dogs with multicentric lymphoma. Journal of Veterinary Internal Medicine, v. 22, n. 3, p. 772, 2008.

LUSTOZA, M. D. Avaliação do estresse oxidativo em cães com insuficiência renal crônica e anemia. 2004. 92 f. Dissertação (Mestrado) - Faculdade de Medicina Veterinária e Zootecnia, Universidade de São Paulo, São Paulo, 2004.

MACCIÒ, A.; MADEDDU, C.; MASSA, D.; MUDU, M. C.; LUSSO, M. R.; GRAMIGNANO, G.; SERPE, R.; MELIS, G. B.; MANTOVANI, G. Hemoglobin levels correlate with interleukin- 6 levels in patients with advanced untreated epithelial ovarian cancer: role of inflammation in cancer-related anemia. Blood, v. 106, n. 1, p. 362-367, 2005.

MADEWELL, B. R.; FELDMAN, B. F. Characterization of anemias associated with neoplasia in small animals. Journal of the American Veterinary Medical Association, v. 176, n. 5, p. 419-425, 1980.

MAHDAVI, R.; FARAMARZI, E.; SEYEDREZAZADEH, E.; MOHAMMAD-ZADEH, M.; POURMOGHADDAM, M. Evaluation of oxidative stress, antioxidant status and serum vitamin C levels in cancer patients. Biological Trace Element Research, v. 130, p. 1-6, 2009.

MANDELKER, L. Introduction to oxidative stress and mitochondrial dysfunction.

Veterinary Clinics of North America: Small Animal Practice, v. 38, p. 1-30, 2008.

MANTOVANI, G.; MACCIÒ, A.; MADEDDU, C.; MURA, L.; MASSA, E.;

GRAMIGNANO, G.; LUSSO, M. R.; MURGIA, V.; CAMBONI, P.; FERRELI, L. Reactive oxygen species, antioxidant mechanisms, and serum cytokine levels in cancer patients: impact of an antioxidant treatment. Journal of Environmental Pathology, Toxicology and

Oncology, v. 22, n. 1, p. 17-28, 2003.

MEANS, R. T.; KRANTZ, S. B. Progress in understanding the pathogenesis of the anemia of chronic disease. Blood, v. 80, n. 7, p. 1639-1647, 1992.

MELISSINOS, K. D.; DELIDOV, A. Z.; VARSOV, A. G.; GEGIETTI, S. S.; DRIVAS, G. J. Serum and erythrocyte glutathione reductase activity in chronic renal failure. Nephron, v. 28, n. 2, p. 76-79, 1981. 
MILLER, A. G.; MORLEY, P. S.; RAO, S.; AVERY, A. C.; LANA, S. E.; OLVER, C. S. Anemia is associated with decreased survival time in dogs with lymphoma. Journal of Veterinary Internal Medicine, v. 23, p. 116-122, 2009.

MORABITO, F.; CRISTANI, M.; SAIJA, C.; STELITANO, C.; CALLEA, V.; TOMAINO, A.; MINCIULLO, P. L.; GANGEMI, S. Lipid peroxidation and protein oxidation in patients affected by Hodgkin's lymphoma. Mediators of Inflammation, v. 13, n. 5-6, p. 381-383, 2004.

MOULTON, J. E.; HARVEY, J. W. Tumors of the lymphoid and hematopoietic tissues. In: MOULTON, J. E. Tumors in Domestic Animals. 3. ed. California: University of California Press, 1990. cap. 6, p. 231-307.

NEUMANN, C. A.; KRAUSE, D. S.; CARMAN, C. V.; DAS, S.; DUBEY, D. P.;

ABRAHAM, J. L.; BRONSON, R. T.; FUJIWARA, Y.; ORKIN, S. H.; VAN ETTEN, R. A. Essential role for the peroxiredoxin Prdx1 in erythrocyte antioxidant defence and tumour suppression. Nature, v. 424, p. 561-565, 2003.

NOVOTNA, B.; BAGRYANTSEVA, Y.; SISKOVA, M.; NEUWIRTOVA, R. Oxidative DNA damage in bone marrow cells of patients with low-risk myelodysplastic syndrome. Leukemia Research, v. 33, p. 340-343, 2009.

OGILVIE, G. K. Paraneoplastic syndromes. In: ETTINGER, S. J.; FELDMAN, E. C. Textbook of veterinary internal medicine. 5. ed. Philadelphia: W. B. Saunders Company, 2000. cap. 97, p. 498-506.

OWEN, L. WHO Clinical Staging. In: DOCUMENT VPH / CMO / 80, 20. Geneva: World Health Organization, 1980. p. 47.

PAGLIA, D. E.; VALENTINE, W. N. Studies on the quantitative and qualitative characterization of erythrocyte glutathione peroxidase. Journal of Laboratory and Clinical Medicine, v. 70, n. 1, p. 158-169, 1967.

PAVRI, R. S.; DAS GUPTA, A.; BAXI, A. J.; ADVANI, S. H. Further evidence for oxidative damage to hemoglobin and red cell membrane in leukemia. Leukemia Research, v. 7, n. 6, p. 729-733, 1983. 
PETRIE, A.; WATSON, P. Statistics for veterinary and animal science. 1. ed. London: Blackwell Science Ltd., 1999. 243 p.

RIFKIND, J. M.; NAGABABU, E.; RAMASAMY, S.; RAVI, L. B. Hemoglobin redox reactions and oxidative stress. Redox Report, v. 8, n. 5, p. 234-237, 2003.

SANTOS, M. D. Avaliação do estresse oxidativo em gatos com insuficiência renal crônica e anemia. 2005. 79 f. Dissertação (Mestrado) - Faculdade de Medicina Veterinária e Zootecnia, Universidade de São Paulo, São Paulo, 2005.

SHACTER, E.; WILLIAMS, J. A.; HINSON, R. M.; SENTÜRKER, S.; LEE, Y. Oxidative stress interferes with cancer chemotherapy: inhibition of lymphoma cell apoptosis and phagocytosis. Blood, v. 96, n. 1, p. 307-313, 2000.

SIES, H. Strategies of antioxidant defense. European Journal of Biochemical, v. 215, p. 213-219, 1993.

SLATTER, D. Fundamentals of veterinary ophthalmology. 2. ed. Philadelphia: W. B. Saunders Company, 1990. Bibliografia: p. 304-337.

SOMOGYI, A.; ROSTA, K.; PUSZTAI, P.; TULASSAY, Z.; NAGY, G. Antioxidant measurements. Physiological Measurement, v. 28, p. R41-R55, 2007.

SZCZUBIAL, M.; KANKOFER, M.; LOPUSZYNSKI, W.; DABROWSKI, R.; LIPKO, J. Oxidative stress parameters in bitches with mammary gland tumours. Journal of Veterinary Medicine, v. 51, p. 336-340, 2004.

VAIL, D. M.; THAMM, D. H. Hematopoietic tumors. In: ETTINGER, S. J.; FELDMAN, E. C. Textbook of veterinary internal medicine. 6. ed. Philadelphia: W. B. Saunders Company, 2005. cap. 181, p. 732-747.

VAIL, D. M.; YOUNG, K. M. Hematopoietic tumors. In: WITHROW, S. J.; VAIL, D. M. Withrow \& MacEwen's small animal clinical oncology. 4. ed. Missouri: Saunders Elsevier, 2007. cap. 31, p. 699-784. 
VAJDOVICH, P.; KRISKA, T.; MÉZES, M.; SZABÓ, P. R.; BALOGH, N.; BÁNFI, A.; ARANY-TÓTH, A.; GAÁL, T.; JAKUS, J. Redox status of dogs with non-Hodgkin lymphomas. An ESR study. Cancer Letters, v. 224, n. 2, p. 339-346, 2005.

VALKO, M.; IZAKOVIC, M.; MAZUR, M.; RHODES, C. J.; TELSER, J. Role of oxygen radicals in DNA damage and cancer incidence. Molecular and Cellular Biochemistry, v. 266, p. 37-56, 2004.

VALKO, M.; RHODES, C. J.; MONCOL, J.; IZAKOVIC, M.; MAZUR, M. Free radicals, metals and antioxidants in oxidative stress-induced cancer. Chemico-Biological Interactions, v. 160 , p. 1-40, 2006.

WEISS, D. J. A retrospective study of the incidence and the classification of bone marrow disorders in the dog at a veterinary teaching hospital (1996-2004). Journal of Veterinary Internal Medicine, v. 20, p. 955-961, 2006.

WEISS, D. J. Nonregenerative anemias. In: BONAGURA, J. D.; TWEDT, D. C. Kirk's current veterinary therapy XIV. 14. ed. Missouri: Saunders Elsevier, 2009. cap. 58, p. 272276.

WELLER, R. E. Paraneoplastic disorders in dogs with hematopoietic tumors. Veterinary Clinics of North America: Small Animal Practice, v. 15, n. 4, p. 805-816, 1985.

WELLMAN, M. L. Neoplasia hematopoiética e linfóide. In: BOJRAB, M. J. Mecanismos da moléstia na cirurgia dos pequenos animais. 2. ed. São Paulo: Manole, 1996. cap. 92, p. 737-749.

WHITFORD, E. L. Lymphocytic lymphosarcoma of the canine eye. Journal of the American Veterinary Medical Association, v. 147, n. 8, p. 837-838, 1965.

WILKINSON, G. T.; HARVEY, R. G. Atlas colorido de dermatologia dos pequenos animais. São Paulo: Manole, 1996. p. 219-242.

WINTER, J. L.; BARBER, L. G.; FREEMAN, L.; GRIESSMAYR, P. C.; MILBURY, P. E.; BLUMBERG, J. B. Antioxidant status and biomarkers of oxidative stress in dogs with lymphoma. Journal of Veterinary Internal Medicine, v. 23, p. 311-316, 2009. 
WU, G.; FANG, Y. Z.; YANG, S.; LUPTON, J. R.; TURNER, N. D. Glutathione metabolism and its implications for health. The Journal of Nutrition, v. 134, p. 489-492, 2004.

ZHAO, Y.; SEEFELDT, T.; CHEN, W.; CARLSON, L.; STOEBNER, A.; HANSON, S.; FOLL, R.; MATTHEES, D. P.; PALAKURTHI, S.; GUAN, X. Increase in thiol oxidative stress via glutathione reductase inhibition as a novel approach to enhance cancer sensitivity to X-ray irradiation. Free Radical Biology \& Medicine, v. 47, p. 176-183, 2009.

ZIMA, T.; SPICKA, I.; STIPEK, S.; CRKOVSKÁ, J.; PLÁTENÍK, J.; MERTA, M.; TESAR, $\mathrm{V}$. Antioxidant enzymes and lipid peroxidation in patients with multiple myeloma.

Neoplasma, v. 43, n. 2, p. 69-73, 1996. 
APÊNDICE A - Valores relativos aos hemogramas dos animais do grupo controle. São Paulo, 2010

(continua)

\begin{tabular}{|c|c|c|c|c|c|c|c|c|c|c|c|c|c|c|}
\hline \multirow[b]{2}{*}{ Animal } & \multicolumn{14}{|c|}{ HEMOGRAMA } \\
\hline & $\begin{array}{l}\text { Hemácias } \\
\left(\times 10^{6} / \mathrm{mm}^{3}\right)\end{array}$ & $\begin{array}{c}\text { Hematócrito } \\
(\%)\end{array}$ & $\begin{array}{c}\text { Hemoglobina } \\
\text { (g/dL) }\end{array}$ & $\begin{array}{l}\text { V.C.M. } \\
\text { (fl) }\end{array}$ & $\begin{array}{c}\text { H.C.M. } \\
\text { (pg) }\end{array}$ & $\begin{array}{c}\text { C.H.C.M. } \\
\text { (\%) }\end{array}$ & $\begin{array}{l}\text { Leucócitos } \\
\qquad\left(/ \mathbf{m m}^{3}\right)\end{array}$ & $\begin{array}{l}\text { Neutrófilos } \\
\qquad\left(/ \mathbf{m m}^{3}\right)\end{array}$ & $\begin{array}{c}\text { Eosinófilos } \\
\qquad\left(/ \mathbf{m m}^{3}\right)\end{array}$ & $\begin{array}{c}\text { Basófilos } \\
\left(/ \mathbf{m m}^{3}\right)\end{array}$ & $\begin{array}{c}\text { Linfócitos } \\
\text { Típicos } \\
\left(/ \mathbf{m m}^{3}\right)\end{array}$ & $\begin{array}{c}\text { Linfócitos } \\
\text { Atípicos } \\
\left(/ \mathbf{m m}^{3}\right)\end{array}$ & $\begin{array}{c}\text { Monócitos } \\
\left(/ \mathbf{m m}^{3}\right)\end{array}$ & $\begin{array}{c}\text { Plaquetas } \\
\left(/ \mathbf{m m}^{3}\right)\end{array}$ \\
\hline 1 & 7,9 & 53 & 16,9 & 67,09 & 21,39 & 31,89 & 7.500 & 4.575 & 375 & 0 & 2.475 & 0 & 75 & 329.000 \\
\hline 2 & 7,9 & 55 & 19,9 & 69,62 & 25,19 & 36,18 & 7.200 & 5.616 & 216 & 0 & 1.080 & 0 & 288 & 335.000 \\
\hline 3 & 8,6 & 63 & 20,7 & 73,26 & 24,07 & 32,86 & 4.400 & 3.124 & 220 & 0 & 1.012 & 0 & 44 & 307.000 \\
\hline 4 & 7,2 & 46 & 16,1 & 63,89 & 22,36 & 35,00 & 8.800 & 4.664 & 792 & 0 & 2.728 & 0 & 616 & 269.000 \\
\hline 5 & 6,0 & 43 & 14,2 & 71,67 & 23,67 & 33,02 & 18.900 & 14.175 & 756 & 0 & 3.024 & 0 & 945 & 464.000 \\
\hline 6 & 6,9 & 48 & 16,6 & 69,57 & 24,06 & 34,58 & 8.500 & 6.120 & 85 & 0 & 1.955 & 0 & 340 & 470.000 \\
\hline 7 & 7,2 & 52 & 17,4 & 72,22 & 24,17 & 33,46 & 6.000 & 4.020 & 300 & 0 & 1.320 & 0 & 360 & 362.000 \\
\hline 8 & 6,4 & 49 & 16,1 & 76,56 & 25,16 & 32,86 & 5.300 & 2.120 & 371 & 0 & 2.173 & 0 & 636 & 293.000 \\
\hline 9 & 7,9 & 57 & 18,0 & 72,15 & 22,78 & 31,58 & 11.800 & 9.440 & 118 & 0 & 2.124 & 0 & 118 & 246.000 \\
\hline 10 & 8,1 & 56 & 17,8 & 69,14 & 21,98 & 31,79 & 11.500 & 9.085 & 1.150 & 0 & 690 & 0 & 575 & 346.000 \\
\hline 11 & 6,0 & 40 & 12,9 & 66,67 & 21,50 & 32,25 & 6.800 & 3.808 & 204 & 0 & 2.244 & 0 & 544 & 541.000 \\
\hline 12 & 6,7 & 47 & 15,1 & 70,15 & 22,54 & 32,13 & 7.700 & 3.311 & 1.540 & 77 & 1.925 & 0 & 847 & 415.000 \\
\hline 13 & 5,5 & 40 & 12,5 & 72,73 & 22,73 & 31,25 & 10.300 & 7.004 & 206 & 0 & 2.884 & 0 & 206 & 581.000 \\
\hline 14 & 6,8 & 48 & 15,1 & 70,59 & 22,21 & 31,46 & 7.400 & $\begin{array}{l}5.328 \\
\end{array}$ & 222 & 0 & 1.332 & 0 & 518 & 612.000 \\
\hline
\end{tabular}


(conclusão)

\begin{tabular}{|c|c|c|c|c|c|c|c|c|c|c|c|c|c|c|}
\hline \multirow[b]{2}{*}{ Animal } & \multicolumn{14}{|c|}{ HEMOGRAMA } \\
\hline & $\begin{array}{l}\text { Hemácias } \\
\left(\times 10^{6} / \mathbf{m m}^{3}\right)\end{array}$ & $\begin{array}{c}\text { Hematócrito } \\
(\%)\end{array}$ & $\begin{array}{c}\text { Hemoglobina } \\
\text { (g/dL) }\end{array}$ & $\begin{array}{c}\text { V.C.M. } \\
\text { (fl) }\end{array}$ & $\begin{array}{c}\text { H.C.M. } \\
\text { (pg) }\end{array}$ & $\begin{array}{c}\text { C.H.C.M. } \\
(\%)\end{array}$ & $\begin{array}{c}\text { Leucócitos } \\
\qquad\left(/ \mathbf{m m}^{3}\right)\end{array}$ & $\begin{array}{c}\text { Neutrófilos } \\
\qquad\left(/ \mathbf{m m}^{3}\right)\end{array}$ & $\begin{array}{c}\text { Eosinófilos } \\
\qquad\left(/ \mathbf{m m}^{3}\right)\end{array}$ & $\begin{array}{c}\text { Basófilos } \\
\left(/ \mathbf{m m}^{3}\right)\end{array}$ & $\begin{array}{c}\text { Linfócitos } \\
\text { Típicos } \\
\left(/ \mathbf{m m}^{3}\right)\end{array}$ & $\begin{array}{c}\text { Linfócitos } \\
\text { Atípicos } \\
\left(/ \mathbf{m m}^{3}\right)\end{array}$ & $\begin{array}{c}\text { Monócitos } \\
\text { (/mm³) }\end{array}$ & $\begin{array}{c}\text { Plaquetas } \\
\qquad\left(/ \mathbf{m m}^{3}\right)\end{array}$ \\
\hline 15 & 6,9 & 50 & 16,6 & 72,46 & 24,06 & 33,20 & 7.900 & 4.740 & 474 & 0 & 2.291 & 0 & 395 & 261.000 \\
\hline 16 & 7,7 & 56 & 18,0 & 72,73 & 23,38 & 32,14 & 9.600 & 6.432 & 576 & 0 & 1.248 & 0 & 1.344 & 256.000 \\
\hline 17 & 7,3 & 49 & 16,5 & 67,12 & 22,60 & 33,67 & 13.200 & 8.448 & 1.716 & 0 & 2.640 & 0 & 396 & 267.000 \\
\hline 18 & 6,5 & 45 & 14,0 & 69,23 & 21,54 & 31,11 & 13.000 & 10.010 & 520 & 0 & 1.950 & 0 & 520 & 277.000 \\
\hline 19 & 5,8 & 42 & 13,6 & 72,41 & 23,45 & 32,38 & 15.200 & 9.424 & 608 & 0 & 4.256 & 0 & 912 & 332.000 \\
\hline 20 & 7,4 & 47 & 16,2 & 63,51 & 21,89 & 34,47 & 6.700 & 4.556 & 469 & 0 & 1.072 & 0 & 603 & 244.000 \\
\hline
\end{tabular}

VCM - Volume Corpuscular Médio; HCM - Hemoglobina Corpuscular Média; CHCM - Concentração de Hemoglobina Corpuscular Média 
APÊNDICE B - Valores relativos aos exames bioquímicos séricos dos animais do grupo controle - São Paulo - 2010

\begin{tabular}{|c|c|c|c|c|c|c|c|c|c|}
\hline \multirow[b]{2}{*}{ Animal } & \multicolumn{9}{|c|}{ DETERMINAÇÕES BIOQUÍMICAS } \\
\hline & $\begin{array}{c}\text { Uréia } \\
\text { (mg/dL) }\end{array}$ & $\begin{array}{c}\text { Creatinina } \\
\text { (mg/dL) }\end{array}$ & $\begin{array}{c}\text { Proteína Total } \\
\text { (g/dL) }\end{array}$ & $\begin{array}{c}\text { Albumina } \\
\text { (g/dL) }\end{array}$ & $\begin{array}{l}\text { ALT } \\
(\mathrm{U} / \mathrm{L})\end{array}$ & $\begin{array}{c}\text { Fosfatase Alcalina } \\
\text { (U/L) }\end{array}$ & $\begin{array}{c}\text { Billirrubina Total } \\
\text { (mg/dL) }\end{array}$ & $\begin{array}{c}\text { Bilirrubina Direta } \\
(\mathrm{mg} / \mathrm{dL})\end{array}$ & $\begin{array}{c}\text { Billirrubina } \\
\text { Indireta (mg/dL) }\end{array}$ \\
\hline 1 & 44,1 & 1,1 & 6,7 & 3,6 & 22,9 & 18,6 & $<0,25$ & - & - \\
\hline 2 & 22,9 & 1,0 & 6,7 & 3,6 & 29,8 & 43,7 & $<0,25$ & - & - \\
\hline 3 & 35,6 & 1,4 & 6,9 & 3,6 & 23,7 & 19,7 & $<0,25$ & - & - \\
\hline 4 & 49,9 & 0,98 & 6,3 & 2,7 & 25,4 & 32,7 & $<0,25$ & - & - \\
\hline 5 & 27,3 & 0,63 & 7,2 & 2,9 & 16,7 & 17,9 & $<0,25$ & - & - \\
\hline 6 & 29,5 & 0,70 & 7,1 & 3,2 & 50,5 & 9,5 & $<0,25$ & - & - \\
\hline 7 & 60,4 & 0,88 & 7,8 & 3,1 & 22,4 & 29,5 & $<0,25$ & - & - \\
\hline 8 & 22,8 & 0,66 & 7,2 & 3,2 & 21,2 & 27,3 & $<0,25$ & - & - \\
\hline 9 & 32,7 & 0,80 & 7,0 & 2,8 & 18,3 & 35,7 & $<0,25$ & - & - \\
\hline 10 & 29,0 & 0,82 & 7,9 & 3,2 & 37,4 & 22,8 & $<0,25$ & - & - \\
\hline 11 & 48,0 & 0,81 & 6,9 & 2,7 & 15,0 & 16,1 & $<0,25$ & - & - \\
\hline
\end{tabular}


(conclusão)

\begin{tabular}{|c|c|c|c|c|c|c|c|c|c|}
\hline \multirow[b]{2}{*}{ Animal } & \multicolumn{9}{|c|}{ DETERMINAÇÕES BIOQUÍMICAS } \\
\hline & $\begin{array}{l}\text { Uréia } \\
\text { (mg/dL) }\end{array}$ & $\begin{array}{c}\text { Creatinina } \\
\text { (mg/dL) }\end{array}$ & $\begin{array}{c}\text { Proteína Total } \\
\text { (g/dL) }\end{array}$ & $\begin{array}{r}\text { Albumina } \\
\text { (g/dL) }\end{array}$ & $\begin{array}{l}\text { ALT } \\
\text { (U/L) }\end{array}$ & $\begin{array}{l}\text { Fosfatase Alcalina } \\
\text { (U/L) }\end{array}$ & $\begin{array}{c}\text { Billirrubina Total } \\
\text { (mg/dL) }\end{array}$ & $\begin{array}{c}\text { Bilirrubina Direta } \\
(\mathrm{mg} / \mathrm{dL})\end{array}$ & $\begin{array}{c}\text { Billirrubina } \\
\text { Indireta (mg/dL) }\end{array}$ \\
\hline 12 & 30,6 & 0,85 & 6,3 & 2,8 & 21,0 & 12,4 & $<0,25$ & - & - \\
\hline 13 & 43,1 & 0,83 & 6,4 & 2,8 & 23,0 & 44,4 & $<0,25$ & - & - \\
\hline 14 & 28,8 & 0,57 & 7,3 & 3,1 & 12,3 & 8,9 & $<0,25$ & - & - \\
\hline 15 & 29,5 & 0,65 & 7,5 & 3,0 & 37,9 & 17,5 & $<0,25$ & - & - \\
\hline 16 & 36,3 & 0,68 & 7,2 & 3,2 & 32,7 & 15,3 & $<0,25$ & - & - \\
\hline 17 & 37,9 & 0,72 & 7,7 & 3,1 & 33,6 & 24,9 & $<0,25$ & - & - \\
\hline 18 & 28,6 & 0,87 & 7,5 & 3,2 & 20,9 & 8,8 & $<0,25$ & - & - \\
\hline 19 & 45,0 & 0,85 & 6,8 & 2,9 & 13,7 & 45,8 & $<0,25$ & - & - \\
\hline 20 & 50,5 & 0,89 & 7,2 & 3,2 & 28,5 & 10,7 & $<0,25$ & - & - \\
\hline
\end{tabular}


APÊNDICE C - Valores relativos aos hemogramas dos animais com linfoma multicêntrico do grupo experimental sem anemia. São Paulo, 2010

\begin{tabular}{|c|c|c|c|c|c|c|c|c|c|c|c|c|c|c|}
\hline \multirow[b]{2}{*}{ Animal } & \multicolumn{14}{|c|}{ HEMOGRAMA } \\
\hline & $\begin{array}{l}\text { Hemácias } \\
\left(\times 10^{6} / \mathbf{m m}^{3}\right)\end{array}$ & $\begin{array}{c}\text { Hematócrito } \\
\text { (\%) }\end{array}$ & $\begin{array}{c}\text { Hemoglobina } \\
\text { (g/dL) }\end{array}$ & $\begin{array}{c}\text { V.C.M. } \\
\text { (fl) }\end{array}$ & $\begin{array}{c}\text { H.C.M. } \\
\text { (pg) }\end{array}$ & $\begin{array}{c}\text { C.H.C.M. } \\
(\%)\end{array}$ & $\begin{array}{c}\text { Leucócitos } \\
\qquad\left(/ \mathbf{m m}^{3}\right)\end{array}$ & $\begin{array}{l}\text { Neutrófilos } \\
\qquad\left(/ \mathbf{m m}^{3}\right)\end{array}$ & $\begin{array}{c}\text { Eosinófilos } \\
\qquad\left(/ \mathbf{m m}^{3}\right)\end{array}$ & $\begin{array}{c}\text { Basófilos } \\
\left(/ \mathbf{m m}^{3}\right)\end{array}$ & $\begin{array}{c}\text { Linfócitos } \\
\text { Típicos } \\
\left(/ \mathbf{m m}^{3}\right)\end{array}$ & $\begin{array}{c}\text { Linfócitos } \\
\text { Atípicos } \\
\left(/ \mathbf{m m}^{3}\right)\end{array}$ & $\begin{array}{c}\text { Monócitos } \\
\qquad\left(/ \mathbf{m m}^{3}\right)\end{array}$ & $\begin{array}{c}\text { Plaquetas } \\
\left(/ \mathbf{m m}^{3}\right)\end{array}$ \\
\hline 1 & 7,9 & 53 & 17,5 & 67,09 & 22,15 & 33,02 & 6.600 & 4.554 & 0 & 0 & 1.386 & 0 & 660 & 156.000 \\
\hline 2 & 5,75 & 45 & 15,3 & 78,26 & - & 34,00 & 16.200 & 11.340 & 324 & 0 & 3.078 & 0 & 1.458 & 140.000 \\
\hline 3 & 5,5 & 39 & 13,2 & 70,91 & - & 33,85 & 14.300 & 11.869 & 143 & 0 & 2.002 & 0 & 286 & 280.000 \\
\hline $4^{\mathrm{a}}$ & 6,97 & 46,20 & 21,30 & 66,28 & 30,56 & 46,10 & 9.000 & 7.380 & 0 & 0 & 1.260 & 0 & 360 & 514.000 \\
\hline 5 & 5,9 & 39 & 13,2 & 66,10 & 22,37 & 33,85 & 22.800 & 20.064 & 684 & 0 & 912 & 0 & 1.140 & 197.000 \\
\hline $6^{b}$ & 7,8 & 49 & 16,3 & $\begin{array}{ll}62,82 \\
\end{array}$ & 20,90 & 33,27 & 9.300 & 7.533 & 93 & 0 & 1.302 & 0 & 372 & 391.000 \\
\hline 7 & 7,21 & 45 & 13,7 & 62,41 & 19 & 30,44 & 17.200 & 15.996 & 172 & 0 & 860 & 0 & 172 & 219.000 \\
\hline 8 & 7,7 & 52 & 17 & 67,50 & 22,1 & 32,70 & 8.900 & 6.675 & 267 & 0 & 1.246 & 0 & 712 & 328.000 \\
\hline 9 & 6,4 & 39 & 12,2 & $\begin{array}{l}60,94 \\
\end{array}$ & 19,06 & 31,28 & 16.900 & 14.196 & 0 & 0 & 2.197 & 0 & 507 & 350.000 \\
\hline 10 & 6,0 & 40 & 14,4 & 66,67 & 24,0 & 36,00 & 12.800 & 11.520 & 0 & 0 & 256 & 0 & 1.024 & 227.000 \\
\hline
\end{tabular}

VCM - Volume Corpuscular Médio; HCM - Hemoglobina Corpuscular Média; CHCM - Concentração de Hemoglobina Corpuscular Média / ${ }^{\mathrm{a}}$ Discreta anisocitose e policromasia $/{ }^{\mathrm{b}}$ Monócitos reativos + 
APÊNDICE D - Valores relativos aos exames bioquímicos séricos dos animais com linfoma multicêntrico do grupo experimental sem anemia. São Paulo, 2010

\begin{tabular}{|c|c|c|c|c|c|c|c|c|c|}
\hline \multirow[b]{2}{*}{ Animal } & \multicolumn{9}{|c|}{ DETERMINAÇÕES BIOQUÍMICAS } \\
\hline & $\begin{array}{c}\text { Uréia } \\
\text { (mg/dL) }\end{array}$ & $\begin{array}{c}\text { Creatinina } \\
\text { (mg/dL) }\end{array}$ & $\begin{array}{c}\text { Proteína Total } \\
\text { (g/dL) }\end{array}$ & $\begin{array}{c}\text { Albumina } \\
\text { (g/dL) }\end{array}$ & $\begin{array}{l}\text { ALT } \\
\text { (U/L) }\end{array}$ & $\begin{array}{c}\text { Fosfatase Alcalina } \\
\text { (U/L) }\end{array}$ & $\begin{array}{l}\text { Billirrubina Total } \\
\text { (mg/dL) }\end{array}$ & $\begin{array}{c}\text { Bilirrubina Direta } \\
\text { (mg/dL) }\end{array}$ & $\begin{array}{c}\text { Billirrubina } \\
\text { Indireta (mg/dL) }\end{array}$ \\
\hline 1 & 41,4 & 1,2 & 6,3 & 3,2 & 35,8 & 46,0 & $<0,25$ & - & - \\
\hline 2 & 19,97 & 0,58 & 4,56 & 2,63 & 41,9 & 147,4 & $<0,25$ & - & - \\
\hline 3 & 11,2 & 0,95 & 6,4 & 2,6 & 108,1 & 182,3 & $<0,25$ & - & - \\
\hline 4 & 30,3 & 0,45 & 8,3 & 3,5 & 12,7 & 62,0 & $<0,25$ & - & - \\
\hline 5 & 12,8 & 0,72 & 5,7 & 2,5 & 248,7 & 254,0 & $<0,25$ & - & - \\
\hline 6 & 29,8 & 0,86 & 5,0 & 2,3 & 34,0 & 14,1 & $<0,25$ & - & - \\
\hline 7 & 23,41 & 0,81 & - & - & 315,0 & 160,0 & $<0,25$ & - & - \\
\hline 8 & 53,0 & 2,0 & - & - & 68,0 & 107,0 & $<0,25$ & - & - \\
\hline 9 & 23 & 0,75 & - & - & 47 & 141 & $<0,25$ & - & - \\
\hline 10 & 50,6 & 0,91 & 6,1 & 2,4 & 132,6 & 48,7 & $<0,25$ & - & - \\
\hline
\end{tabular}

ALT - Alanina Aminotransferase 
APÊNDICE E - Valores relativos aos hemogramas dos animais com linfoma multicêntrico do grupo experimental com anemia. São Paulo, 2010

\begin{tabular}{|c|c|c|c|c|c|c|c|c|c|c|c|c|c|c|}
\hline \multirow[b]{2}{*}{ Animal } & \multicolumn{14}{|c|}{ HEMOGRAMA } \\
\hline & $\begin{array}{c}\text { Hemácias } \\
\left(\times 10^{6} / \mathbf{m m}^{3}\right)\end{array}$ & $\begin{array}{c}\text { Hematócrito } \\
(\%)\end{array}$ & $\begin{array}{c}\text { Hemoglobina } \\
\text { (g/dL) }\end{array}$ & $\begin{array}{c}\text { V.C.M. } \\
\text { (fl) }\end{array}$ & $\begin{array}{c}\text { H.C.M. } \\
\text { (pg) }\end{array}$ & $\begin{array}{c}\text { C.H.C.M. } \\
(\%)\end{array}$ & $\begin{array}{c}\text { Leucócitos } \\
\left(/ \mathbf{m m}^{3}\right)\end{array}$ & $\begin{array}{c}\text { Neutrófilos } \\
\left(/ \mathbf{m m}^{3}\right)\end{array}$ & $\begin{array}{c}\text { Eosinófilos } \\
\left(/ \mathbf{m m}^{3}\right)\end{array}$ & $\begin{array}{c}\text { Basófilos } \\
\left(/ \mathbf{m m}^{3}\right)\end{array}$ & $\begin{array}{c}\text { Linfócitos } \\
\text { Típicos } \\
\left(/ \mathbf{m m}^{3}\right)\end{array}$ & $\begin{array}{l}\text { Linfócitos } \\
\text { Atípicos } \\
\left(/ \mathbf{m m}^{3}\right)\end{array}$ & $\begin{array}{c}\text { Monócitos } \\
\left(/ \mathbf{m m}^{3}\right)\end{array}$ & $\begin{array}{c}\text { Plaquetas } \\
\left(/ \mathbf{m m}^{3}\right)\end{array}$ \\
\hline $1^{\mathrm{a}}$ & 4,6 & 31 & 10,9 & 67,39 & 23,70 & 35,16 & 16.100 & 14.490 & 0 & 0 & 966 & 0 & 644 & 275.000 \\
\hline $2^{b}$ & 4,41 & 28 & 9,1 & 63,72 & 20,69 & 32,38 & 17.800 & 15.664 & 0 & 0 & 1.246 & 0 & 890 & 243.000 \\
\hline 3 & 5,1 & 35 & 11,2 & 68,63 & 21,96 & 32,00 & 11.100 & 8.880 & 0 & 0 & 1.554 & 0 & 666 & 126.000 \\
\hline $4^{c}$ & 3,97 & 26,80 & 9,00 & 67,51 & 22,67 & 33,58 & 7.603 & $\begin{array}{l}5.398 \\
\end{array}$ & 0 & 0 & 1.825 & 0 & 380 & 36.000 \\
\hline 5 & 4,6 & 30 & 10,2 & 65,22 & 22,17 & 34,00 & 19.400 & 13.774 & 194 & 0 & 4.268 & 970 & 194 & 56.000 \\
\hline $6^{d}$ & - & 28 & - & - & - & - & 16.500 & - & - & - & - & - & - & 294.000 \\
\hline $7^{e}$ & 5,3 & 34 & 11,5 & 64,15 & 21,7 & 33,82 & 28.200 & 26.508 & 282 & 0 & 846 & 0 & 564 & 186.000 \\
\hline $8^{f}$ & 3,4 & 24 & 10,5 & 80,00 & 33,33 & 41,67 & 14.400 & 1.152 & 0 & 0 & 12.960 & 288 & 0 & 82.000 \\
\hline $9^{g}$ & 3,9 & 25 & 8,1 & 64,10 & 20,77 & 32,40 & 10.600 & 8.162 & 0 & 0 & 2.226 & 0 & 212 & 251.000 \\
\hline $10^{h}$ & 3,4 & 22 & 7,6 & 64,71 & 22,35 & 34,55 & 114.000 & 23.940 & 0 & 0 & 66.120 & 0 & 1.140 & 100.000 \\
\hline $11^{\mathrm{i}}$ & 4,7 & 27 & 9,3 & 57,45 & 19,79 & 34,44 & 11.000 & 9.570 & 0 & 0 & 1.320 & 0 & 110 & 299.000 \\
\hline $12^{j}$ & 4,8 & 28 & 9,9 & \begin{tabular}{|l|l|}
58,33 \\
\end{tabular} & 20,63 & 35,36 & 22.200 & 20.424 & 0 & 0 & 1.332 & 0 & 444 & 638.000 \\
\hline $13^{k}$ & 3,1 & 18 & 7,1 & 58,06 & 22,90 & 39,44 & 6.400 & 4.544 & 0 & 0 & 1.536 & 0 & 320 & 111.000 \\
\hline $14^{1}$ & 5,0 & 32 & 10,9 & 64,00 & 21,80 & 34,06 & 10.100 & 7.676 & 0 & 0 & 2.020 & 0 & 404 & 225.000 \\
\hline
\end{tabular}

VCM - Volume Corpuscular Médio; HCM - Hemoglobina Corpuscular Média; CHCM - Concentração de Hemoglobina Corpuscular Média / ${ }^{\mathrm{a}}$ Anisocitose +; Neutrófilos segmentados pouco segmentados + / ${ }^{\mathrm{b}}$

Anisocitose +; Policromasia +; Neutrófilos segmentados pouco segmentados + e alguns com granulações tóxicas / ${ }^{\mathrm{c}} 21 \%$ Eritroblastos; Anisocitose ++ ; Policromasia +; Presença de Corpúsculos de Howell-Jolly; Neutrófilos segmentados pouco segmentados $+++\mathrm{e}$ alguns com granulações tóxicas $/{ }^{\mathrm{d}}$ Hemograma completo indisponível devido atendimento em emergência $/{ }^{\mathrm{e}}$ Anisocitose $++/{ }^{\mathrm{f}}$ Anisocitose $+;$ Policromasia $+/ \mathrm{g}$ Anisocitose + ; Policromasia $+/{ }^{\mathrm{h}}$ Anisocitose + ; Policromasia $(+) /{ }^{\mathrm{i}}$ Anisocitose + ; Macrocitose + ; Policromasia $+/ /{ }^{\mathrm{j}}$ Anisocitose + ; Neutrófilos com hipersegmentação $+/{ }^{\mathrm{k}}$ Anisocitose $+;$ Macrocitose $+;$ Hemácias em rouleaux +; Linfócitos reativos $++/{ }^{1}$ Presença de linfoblastos; Neutrófilos com hipersegmentação + 
APÊNDICE F - Valores relativos aos exames bioquímicos séricos dos animais com linfoma multicêntrico do grupo experimental com anemia. São Paulo, 2010

\begin{tabular}{|c|c|c|c|c|c|c|c|c|c|}
\hline \multirow[b]{2}{*}{ Animal } & \multicolumn{9}{|c|}{ DETERMINAÇÕES BIOQUÍMICAS } \\
\hline & $\begin{array}{c}\text { Uréia } \\
\text { (mg/dL) }\end{array}$ & $\begin{array}{c}\text { Creatinina } \\
\text { (mg/dL) }\end{array}$ & $\begin{array}{c}\text { Protéína Total } \\
\text { (g/dL) }\end{array}$ & $\begin{array}{c}\text { Albumina } \\
\text { (g/dL) }\end{array}$ & $\begin{array}{l}\text { ALT } \\
\text { (U/L) }\end{array}$ & $\begin{array}{c}\text { Fosfatase Alcalina } \\
\text { (U/L) }\end{array}$ & $\begin{array}{c}\text { Billirrubina Total } \\
\text { (mg/dL) }\end{array}$ & $\begin{array}{c}\text { Bilirrubina Direta } \\
(\mathrm{mg} / \mathrm{dL})\end{array}$ & $\begin{array}{c}\text { Billirrubina } \\
\text { Indireta }(\mathrm{mg} / \mathrm{dL})\end{array}$ \\
\hline 1 & 11,4 & 0,97 & 5,3 & 2,9 & 15,1 & 131,0 & $<0,25$ & - & - \\
\hline 2 & 45,1 & 0,64 & 6,0 & 2,7 & 20,0 & 157,0 & $<0,25$ & - & - \\
\hline 3 & 27,5 & 0,81 & 6,6 & 3,2 & 55,2 & 200,6 & $<0,25$ & - & - \\
\hline 4 & 33,0 & 1,70 & 4,32 & 1,90 & 61,0 & $1.324,0$ & 0,35 & 0,26 & 0,09 \\
\hline 5 & 23,3 & 1,46 & 5,8 & 2,4 & 103 & 113,3 & $<0,25$ & - & - \\
\hline 6 & 30,9 & 0,42 & 4,5 & 2,3 & 25,9 & 47,9 & $<0,25$ & - & - \\
\hline 7 & 33,0 & 0,79 & 6,2 & 3,0 & 19,0 & 270,0 & $<0,25$ & - & - \\
\hline 8 & 27,3 & 0,76 & 8,2 & 2,2 & 14,1 & 20,4 & $<0,25$ & - & - \\
\hline 9 & 7,5 & 1,0 & 6,6 & 2,6 & 7,7 & 33,3 & $<0,25$ & - & - \\
\hline 10 & 27,2 & 0,67 & 5,6 & 2,9 & 14,1 & 18,1 & $<0,25$ & - & - \\
\hline 11 & 29,0 & 0,66 & 7,3 & 2,6 & 20,9 & 74,3 & $<0,25$ & - & - \\
\hline 12 & 60,4 & 0,73 & 6,2 & 2,4 & 16,4 & 23,8 & 0,60 & 0,46 & 0,14 \\
\hline 13 & 36,1 & 0,84 & 6,2 & 1,9 & 35,0 & 167,7 & $<0,25$ & - & - \\
\hline 14 & 24,9 & 0,81 & 6,3 & 2,6 & 7,7 & 39,7 & $<0,25$ & - & - \\
\hline
\end{tabular}

ALT - Alanina Aminotransferase 
APÊNDICE G - Avaliação dos mielogramas relativos aos animais com linfoma multicêntrico do grupo experimental sem anemia. São Paulo, 2010

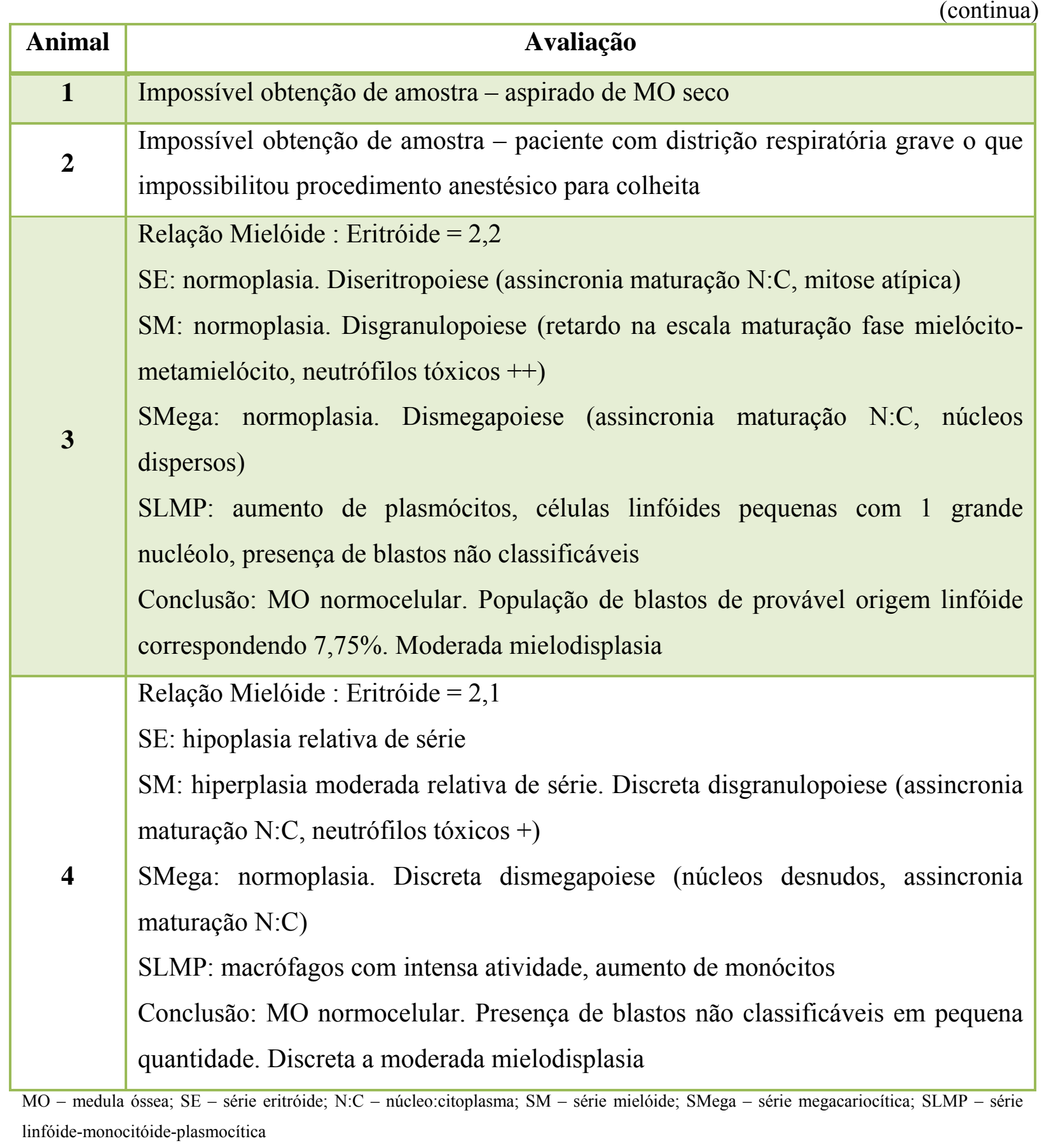


(continua)

\begin{tabular}{|c|c|}
\hline Animal & Avaliação \\
\hline 5 & $\begin{array}{l}\text { Relação Mielóide : Eritróide }=1,77 \\
\text { SE: normoplasia de série. Moderada diseritropoiese (assincronia maturação N:C, } \\
\text { figuras de mitose atípica) } \\
\text { SM: normoplasia de série. Moderada disgranulopoiese (assincronia maturação } \\
\text { N:C, neutrófilos tóxicos }++ \text { ) } \\
\text { SMega: hiperplasia de série. Sem alterações na escala de maturação } \\
\text { SLMP: macrófagos em quantidade e atividade normal. Presença de população } \\
\text { blástica não classificável de provável origem linfóide representando } 4 \% \text { das } \\
\text { células nucleadas da amostra } \\
\text { Conclusão: MO hipercelular em relação à idade. Depósitos de ferro adequados e } \\
\text { compatíveis com a idade. Presença de população blástica de provável origem } \\
\text { linfóide representando } 4 \% \text { das células nucleadas da amostra }\end{array}$ \\
\hline 6 & $\begin{array}{l}\text { Relação Mielóide : Eritróide }=1,55 \\
\text { SE: normoplasia de série } \\
\text { SM: normoplasia de série. Discreta disgranulopoiese (neutrófilos tóxicos ++) } \\
\text { SMega: discreta hiperplasia de série. Sem alterações morfológicas ou na } \\
\text { escalação de maturação } \\
\text { SLMP: aumento da população de macrófagos, com grande aumento dos } \\
\text { depósitos de ferro intracitoplasmáticos e figuras de eritrofagocitose. Presença de } \\
\text { raros blastos não classificáveis (2\%) } \\
\text { Conclusão: MO normocelular, com discreta disgranulopoiese / dishematopoiese. } \\
\text { Grande quantidade de macrófagos com grande quantidade de depósitos de ferro e } \\
2 \% \text { de blastos não classificáveis }\end{array}$ \\
\hline
\end{tabular}


(continua)

\begin{tabular}{|c|c|}
\hline Animal & Avaliação \\
\hline 7 & $\begin{array}{l}\text { Relação Mielóide : Eritróide }=2,2 \\
\text { SE: relativa hipoplasia de série. Discreta diseritropoiese (assincronia maturação } \\
\text { N:C) } \\
\text { SM: relativa hipoplasia de série. Moderada a intensa disgranulopoiese (retardo na } \\
\text { escala maturação na fase promielócito-mielócito, assincronia maturação N:C, } \\
\text { neutrófilos tóxicos }++ \text { ) } \\
\text { SMega: hiperplasia discreta de série. Sem alterações morfológicas } \\
\text { SLMP: macrófagos com intensa atividade, inclusive figuras de eritrofagocitose. } \\
\text { Presença de raros linfoblastos } \\
\text { Conclusão: MO normocelular. Dishematopoiese com moderada a intensa } \\
\text { disgranulopoiese }\end{array}$ \\
\hline 8 & $\begin{array}{l}\text { Relação Mielóide : Eritróide }=1,7 \\
\text { SE: normoplasia de série } \\
\text { SM: normoplasia de série. Discreta disgranulopoiese (neutrófilos tóxicos }+ \text { ) } \\
\text { SMega: discreta hiperplasia } \\
\text { SLMP: presença de blastos não classificáveis ( } 2,25 \%) \text {. Displasia? } \\
\text { Conclusão: Avaliação de celularidade comprometida devido ausência de grumos } \\
\text { na amostra. Presença de população de blastos não classificáveis, correspondendo a } \\
2,25 \% \text { das células nucleadas da amostra, sugestivos de dishematopoiese }\end{array}$ \\
\hline
\end{tabular}


(conclusão)

\begin{tabular}{|c|c|}
\hline Animal & Avaliação \\
\hline 9 & $\begin{array}{l}\text { Relação Mielóide : Eritróide }=2,3 \\
\text { SE: hipoplasia relativa de série. Discreta a moderada diseritropoiese (figuras de } \\
\text { mitose atípica, assincronia maturação N:C) } \\
\text { SM: normoplasia de série. Moderada disgranulopoiese (neutrófilos tóxicos +++, } \\
\text { figuras mitose atípica, assincronia maturação N:C) } \\
\text { SMega: discreta hiperplasia de série. Dismegapoiese (núcleos dispersos, } \\
\text { anisonucleólise) } \\
\text { SLMP: moderada quantidade de macrófagos com intensa atividade citoplasmática } \\
\text { e grande quantidade de depósitos de ferro intracitoplasmáticos. Presença de } \\
\text { população de blastos de provável origem linfóide (2,75\%), com relação N:C } \\
\text { variável a média, citoplasma intensamente basofílico, cromatina frouxa com } 1 \\
\text { grande nucléolo evidente ou } 2-3 \text { nucléolos evidentes. Presença de pequena } \\
\text { quantidade de células mesenquimais dispersas } \\
\text { Conclusão: MO hipercelular com relação à idade. Moderada dishematopoiese. } \\
\text { Presença de população de blastos de provável origem linfóide representando } 2,75 \% \\
\text { da população de células nucleadas da amostra }\end{array}$ \\
\hline 10 & $\begin{array}{l}\text { Relação Mielóide : Eritróide }=1,3 \\
\text { SE: normoplasia de série. Discreta a moderada diseritropoiese (figuras de mitose } \\
\text { atípica) } \\
\text { SM: normoplasia de série. Moderada disgranulopoiese (figuras de mitose atípica, } \\
\text { retardo na escala de maturação - acúmulo de mieloblastos, promielócitos e } \\
\text { monoblastos, neutrófilos tóxicos }+ \text {, bastonetes gigantes) } \\
\text { SMega: discreta hiperplasia de série, sem alterações morfológicas ou na escala de } \\
\text { maturação } \\
\text { SLMP: presença de população de blastos morfologicamente não classificáveis de } \\
\text { origem mielóide e alguns de origem linfóide } \\
\text { Conclusão: MO hipercelular. Moderada dishematopoiese, raros blastos de provável } \\
\text { origem linfóide }\end{array}$ \\
\hline
\end{tabular}


APÊNDICE H - Avaliação dos mielogramas relativos aos animais com linfoma multicêntrico do grupo experimental com anemia. São Paulo, 2010

(continua)

\begin{tabular}{|c|c|}
\hline Animal & Avaliação \\
\hline 1 & Impossível obtenção de amostra - aspirado de MO seco \\
\hline 2 & $\begin{array}{l}\text { Relação Mielóide : Eritróide }=3,9 \\
\text { SE: discreta a moderada diseritropoiese (assincronia de maturação N:C, figuras } \\
\text { mitose atípica). Relativa hipoplasia de série } \\
\text { SM: discreta a moderada disgranulopoiese (neutrófilos tóxicos }++ \text { ). Relativa } \\
\text { hipoplasia de série } \\
\text { SMega: não foram observados elementos da série } \\
\text { SLMP: visualizados poucos macrófagos sem alterações dignas de nota. Presença } \\
\text { de blastos de provável origem linfóide ( } 5 \% \text { ). Monócitos reativos }+ \\
\text { Conclusão: ausência de grumos para avaliação de celularidade. Discreta a } \\
\text { moderada dishematopoiese. Presença de blastos de provável origem linfóide }\end{array}$ \\
\hline 3 & $\begin{array}{l}\text { Relação Mielóide : Eritróide }=9,5 \text { (hemodiluição) } \\
\text { SE: intensa hipoplasia. Diseritropoiese (assincronia maturação N:C, tendendo à } \\
\text { macrocitose, hipocromia }+ \text {, policromasia }++ \text {, anisocitose }++ \text { ) } \\
\text { SM: moderada a intensa hipoplasia. Moderada disgranulopoiese (assincronia } \\
\text { maturação N:C, neutrófilos tóxicos ++) } \\
\text { SMega: não foram observados elementos da série } \\
\text { SLMP: população linfóide pequena, com predomínio de linfócitos pequenos } \\
\text { típicos. Presença de pequena população de blastos não classificáveis } \\
\text { Conclusão: celularidade MO sem avaliação devido intensa hemodiluição e } \\
\text { ausência de grumos (aparentemente hipocelularidade ou hipercelularidade). } \\
\text { Moderada dishematopoiese. População de blastos pequenos não classificáveis } \\
(12,5 \%)\end{array}$ \\
\hline
\end{tabular}


(continua)

\begin{tabular}{|c|c|}
\hline Animal & Avaliação \\
\hline 4 & $\begin{array}{l}\text { Impossível obtenção de amostra - paciente com distrição respiratória grave o que } \\
\text { impossibilitou procedimento anestésico para colheita }\end{array}$ \\
\hline 5 & $\begin{array}{l}\text { Relação Mielóide : Eritróide }=1,5 \\
\text { SE: hipoplasia relativa de série. Moderada diseritropoiese (assincronia maturação } \\
\text { N:C, fragmentação nuclear, anisocitose }++ \text {, policromasia }+ \text { ) } \\
\text { SM: normoplasia a hipoplasia de série. Moderada disgranulopoiese (assincronia } \\
\text { maturação N:C, neutrófilos tóxicos }++ \text { ) } \\
\text { SMega: não foram observados elementos da série } \\
\text { SLMP: grande quantidade de células linfóides, a maioria apresentando 1-2 grandes } \\
\text { nucléolos evidentes }(24 \%) \\
\text { Conclusão: MO normocelular a hipercelular. Hipoplasia a normoplasia de SE e } \\
\text { SM }\end{array}$ \\
\hline 6 & Impossível obtenção de amostra - paciente veio a óbito antes da colheita \\
\hline 7 & $\begin{array}{l}\text { Relação Mielóide : Eritróide }=1,4 \\
\text { SE: discreta diseritropoiese (fragmentação nuclear) } \\
\text { SM: discreta disgranulopoiese (assincronia maturação N:C, neutrófilos tóxicos }++ \text {, } \\
\text { retardo escala maturação) } \\
\text { SMega: não foram observados elementos da série } \\
\text { SLMP: macrófagos com intensa atividade e aumento de depósito de ferro } \\
\text { intracitoplasmático. Raros linfócitos atípicos correspondendo a } 0,7 \% \text { das células na } \\
\text { amostra (cromatina frouxa, 2-3 nucléolos evidentes, anisonucleólise, citoplasma } \\
\text { escasso) } \\
\text { Conclusão: intensa hemodiluição. Discreta diseritropoiese e disgranulopoiese. } \\
\text { Raras células blásticas }\end{array}$ \\
\hline 8 & $\begin{array}{l}\text { Relação Mielóide : Eritróide }=2,2 \\
\text { SE: intensa hipoplasia de série } \\
\text { SM: intensa hipoplasia de série } \\
\text { SMega: sem alterações } \\
\text { SLMP: macrófagos com intensa atividade. Grande população de linfócitos atípicos } \\
(60,5 \%) \text {, muitos linfoblastos com pleomorfismo nuclear } \\
\text { Conclusão: MO intensamente hipercelular, com aumento dos depósitos de ferro } \\
\text { intracelulares. Intensa hipoplasia de SE e SM. Presença de população linfóide } \\
\text { atípica importante }\end{array}$ \\
\hline
\end{tabular}


(continua)

\begin{tabular}{|c|c|}
\hline Animal & Avaliação \\
\hline 9 & $\begin{array}{l}\text { Relação Mielóide : Eritróide }=3,1 \\
\text { SE: discreta diseritropoiese (assincronia maturação } \mathrm{N}: \mathrm{C} \text { ) } \\
\text { SM: discreta a moderada disgranulopoiese (neutrófilos tóxicos }+ \text {, bastonetes } \\
\text { gigantes) } \\
\text { SMega: não foram observados elementos da série } \\
\text { SLMP: nada digno de nota } \\
\text { População de blastos com intensa basofilia citoplasmática, cromatina condensada, } \\
\text { com } 2-3 \text { nucléolos evidentes de provável origem linfóide correspondendo a } 3,25 \% \\
\text { das células nucleadas da amostra } \\
\text { Conclusão: avaliação de celularidade comprometida. Presença de população } \\
\text { blástica linfóide correspondendo a } 3,25 \% \text { das células nucleadas da amostra, além } \\
\text { de discreta diseritropoiese e moderada disgranulopoiese }\end{array}$ \\
\hline 10 & Impossível obtenção de amostra - aspirado de MO seco \\
\hline 11 & $\begin{array}{l}\text { Relação Mielóide : Eritróide }=1,7 \\
\text { SE: normoplasia de série. Discreta diseritropoiese (figuras mitose atípica) } \\
\text { SM: normoplasia de série. Discreta a moderada disgranulopoiese (figuras mitose } \\
\text { atípica, assincronia maturação N:C) } \\
\text { SMega: normoplasia de série } \\
\text { SLMP: macrófagos com intensa atividade } \\
\text { Presença de raras células mesenquimais e reticulares. Presença de raros blastos de } \\
\text { provável origem linfóide }(2,25 \%) \text { com moderada anisocitose, citoplasma } \\
\text { intensamente basofílico, cromatina grosseira, 2-4 nucléolos pouco evidentes } \\
\text { Conclusão: MO ligeiramente hipercelular em relação à idade. Discreta } \\
\text { dishematopoiese. Raros blastos linfóides }\end{array}$ \\
\hline 12 & $\begin{array}{l}\text { Relação Mielóide : Eritróide }=2,2 \\
\text { SE: normoplasia de série. Discreta diseritropoiese (assincronia maturação N:C, } \\
\text { figuras mitose atípica) } \\
\text { SM: normoplasia de série. Moderada disgranulopoiese (retardo escala maturação, } \\
\text { acúmulo de mielócitos e monoblastos, assincronia de maturação N:C, neutrófilos } \\
\text { tóxicos +, figuras mitose atípica) } \\
\text { SMega: normoplasia de série. Discreta a moderada dismegapoiese (núcleos } \\
\text { dispersos) } \\
\text { SLMP: moderada quantidade de macrófagos com intensa atividade } \\
\text { Presença de pequena quantidade de células reticulares e mesenquimais. Raros } \\
\text { blastos morfologicamente não classificáveis ( } 1,5 \% \text { ) } \\
\text { Conclusão: MO hipercelular. Raros blastos (dishematopoiese?) }\end{array}$ \\
\hline
\end{tabular}


(conclusão)

\begin{tabular}{|c|c|}
\hline Animal & Avaliação \\
\hline 13 & $\begin{array}{l}\text { Relação Mielóide : Eritróide }=2,3 \\
\text { SE: normoplasia de série } \\
\text { SM: normoplasia de série. Discreta a moderada disgranulopoiese (neutrófilos } \\
\text { tóxicos }++ \text { ) } \\
\text { SMega: normoplasia de série. Sem alterações morfológicas ou na escala de } \\
\text { maturação } \\
\text { SLMP: macrófagos normais. Presença de pequena quantidade de blastos não } \\
\text { classificáveis, possivelmente de origem linfóide }(3,25 \%) \\
\text { Conclusão: MO hipercelular em relação à idade. Formação em rouleaux. } \\
\text { Disgranulopoiese e blastos de possível origem linfóide }\end{array}$ \\
\hline 14 & $\begin{array}{l}\text { Relação Mielóide : Eritróide }=1,3 \\
\text { SE: normoplasia de série } \\
\text { SM: normoplasia de série. Discreta a moderada disgranulopoiese (retardo na escala } \\
\text { de maturação na fase mielócito-promielócito, neutrófilos tóxicos }+ \text { ) } \\
\text { SMega: discreta hiperplasia de série. Sem alterações na escala de maturação ou } \\
\text { morfologia } \\
\text { SLMP: discreta a moderada quantidade de macrófagos, com grande quantidade de } \\
\text { depósito de ferro intracitoplasmático. Presença de população linfóide, } \\
\text { predominantemente blastos, de tamanho médio, com um grande nucléolo ou } \\
\text { múltiplos nucléolos, relação N:C variável e citoplasma intensamente basofílico, } \\
\text { representando } 11 \% \text { das células nucleadas da amostra } \\
\text { Conclusão: MO hipercelular em relação à idade. Discreta disgranulopoiese, com } \\
\text { infiltração de população linfóide representando } 11 \% \text { das células nucleadas da } \\
\text { amostra }\end{array}$ \\
\hline
\end{tabular}

